Cochrane Database of Systematic Reviews

\title{
Trypanocidal drugs for chronic asymptomatic Trypanosoma cruzi infection (Review)
}

Villar JC, Perez JG, Cortes OL, Riarte A, Pepper M, Marin-Neto JA, Guyatt GH

Villar JC, Perez JG, Cortes OL, Riarte A, Pepper M, Marin-Neto JA, Guyatt GH. Trypanocidal drugs for chronic asymptomatic Trypanosoma cruzi infection. Cochrane Database of Systematic Reviews 2014, Issue 5. Art. No.: CD003463. DOI: 10.1002/14651858.CD003463.pub2. 
TABLE OF CONTENTS

HEADER 1

ABSTRACT

PLAIN LANGUAGE SUMMARY

SUMMARY OF FINDINGS

BACKGROUND

OBJECTIVES

METHODS

Figure 1.

RESULTS

Figure 2.

Figure 3.

Figure 4.

Figure 5.

Figure 6.

Figure 7.

Figure 8.

DISCUSSION

AUTHORS' CONCLUSIONS

ACKNOWLEDGEMENTS

REFERENCES

CHARACTERISTICS OF STUDIES

DATA AND ANALYSES

Analysis 1.1. Comparison 1 Parasite-related outcomes, Outcome 1 Positive serology.

Analysis 1.2. Comparison 1 Parasite-related outcomes, Outcome 2 Positive PCR: nitroderivatives.

Analysis 1.3. Comparison 1 Parasite-related outcomes, Outcome 3 Positive xenodiagnosis: all populations, all tested drugs. ....

Analysis 1.4. Comparison 1 Parasite-related outcomes, Outcome 4 Mean reduction of antibodies titres: all populations, all tested drugs.

Analysis 2.1. Comparison 2 Patient-related outcomes: efficacy, Outcome 1 ECG abnormalities - RCT data - benznidazole. ........ Analysis 2.2. Comparison 2 Patient-related outcomes: efficacy, Outcome 2 Progression of cardiomyopathy: non-RCT data adults, nitroderivatives.

Analysis 2.3. Comparison 2 Patient-related outcomes: efficacy, Outcome 3 Mortality: non-RCT data - adults, all tested drugs. ..

Analysis 3.1. Comparison 3 Patient-related outcomes: safety, Outcome 1 BZD mild-to-moderate - RCT data only.

Analysis 3.3. Comparison 3 Patient-related outcomes: safety, Outcome 3 BZD severe side effects.

Analysis 3.5. Comparison 3 Patient-related outcomes: safety, Outcome 5 ALLOP - mild-to-moderate - RCT data only.

Analysis 3.6. Comparison 3 Patient-related outcomes: safety, Outcome 6 ALLOP - severe side effects.

Analysis 3.7. Comparison 3 Patient-related outcomes: safety, Outcome 7 NFTMX - severe side effects.

Analysis 3.8. Comparison 3 Patient-related outcomes: safety, Outcome 8 ITRA - severe side effects.

Analysis 3.9. Comparison 3 Patient-related outcomes: safety, Outcome 9 Drug discontinuation - all populations, all drugs. .... APPENDICES

WHAT'S NEW CONTRIBUTIONS OF AUTHORS

DECLARATIONS OF INTEREST

INDEX TERMS 
[Intervention Review]

\section{Trypanocidal drugs for chronic asymptomatic Trypanosoma cruzi infection}

Juan Carlos Villar ${ }^{1}$, Juan Guillermo Perez², Olga Lucia Cortes², Adelina Riarte², Micah Pepper ${ }^{4}$, Jose Antonio Marin-Neto ${ }^{5}$, Gordon H Guyatt6

1Department of Medicine, Universidad Autónoma de Bucaramanga (Colombia), Bucaramanga, Colombia. 2Fundación Cardioinfantil Instituto de Cardiología, Bogota, Colombia. ${ }^{3}$ Departamento de Clínica, Patología y Tratamiento, Instituto Nacional de Parasitología Dr M Fatala Chaben, Buenos Aires, Argentina. ${ }^{4}$ School of Public Health, Boston University, Boston, USA. 5 Medical School of Ribeirao Preto, University of Sao Paulo, Ribeirao Preto, Brazil. ${ }^{6}$ Department of Clinical Epidemiology and Biostatistics, McMaster University, Hamilton, Canada

Contact address: Juan Carlos Villar, Department of Medicine, Universidad Autónoma de Bucaramanga (Colombia), Grupo de Cardiología Preventiva, UNAB Campus el Bosque Calle 157 No. 19-55, Bucaramanga, Santander, Colombia. jvillar@unab.edu.co.

Editorial group: Cochrane Heart Group.

Publication status and date: New search for studies and content updated (no change to conclusions), published in Issue 5, 2014.

Citation: Villar JC, Perez JG, Cortes OL, Riarte A, Pepper M, Marin-Neto JA, Guyatt GH. Trypanocidal drugs for chronic asymptomatic Trypanosoma cruzi infection. Cochrane Database of Systematic Reviews 2014, Issue 5. Art. No.: CD003463. DOI: 10.1002/14651858.CD003463.pub2.

Copyright ( 2014 The Cochrane Collaboration. Published by John Wiley \& Sons, Ltd.

\section{A B S T R A C T}

\section{Background}

Prevention of chronic chagasic cardiomyopathy (CCC) by treating infected populations with trypanocidal therapy (TT) remains a challenge. Despite a renewed enthusiasm for TT, uncertainty regarding its efficacy, concerns about its safety and limited availability remain barriers for a wider use of conventional drugs. We have updated a previous version of this review.

\section{Objectives}

To systematically search, appraise, identify and extract data from eligible studies comparing the outcome of cohorts of seropositive individuals to Trypanosoma cruzi exposed to TT versus placebo or no treatment.

\section{Search methods}

We sought eligible studies in electronic databases (Cochrane Central Register of Controlled Trials (CENTRAL), Issue 1, 2014); MEDLINE (Ovid, 1946 to January week 5 2014); EMBASE (Ovid, 1980 to 2014 week 6) and LILACS (up to 6 May 2010)) by combining terms related with the disease and the treatment. The search also included a Google search, handsearch for references in review or selected articles, and search of expert files. We applied no language restrictions.

\section{Selection criteria}

Review authors screened the retrieved references for eligibility (those dealing with human participants treated with TT) and then assessed the pre-selected studies in full for inclusion. We included randomised controlled trials (RCTs) and observational studies that provided data on either mortality or clinical progression of CCC after at least four years of follow-up.

\section{Data collection and analysis}

Teams of two review authors independently carried out the study selection, data extraction and risk of bias assessment, with a referee resolving disagreement within the pairs. Data collection included study design, characteristics of the population and interventions or exposures and outcome measures. We defined categories of outcome data as parasite-related (positive serology, xenodiagnosis or polymerase chain reaction (PCR) after TT) and participant-related (including efficacy outcomes such as progression towards CCC, all-cause 
mortality and side effects of TT). We reported pooled outcome data as Mantel-Haenszel odds ratios (OR) or standardised mean differences (SMD) along with 95\% confidence intervals (CI), using a random-effects model. $\left.\right|^{2}$ statistics provided an estimate of heterogeneity across studies. We conducted an exploratory meta-regression analysis of the relationship between positive-serology and progression of CCC or mortality.

\section{Main results}

We included 13 studies involving 4229 participants (six RCTs, $n=1096$, five RCTs of intermediate risk of bias, one RCT of high risk of bias; four non-randomised experiments, $n=1639$ and three observational studies, $n=1494$ ). Ten studies tested nitroderivative drugs nifurtimox or benznidazole (three exposed participants to allopurinol, one to itraconazole). Five studies were conducted in Brazil, five in Argentina, one in Bolivia, one in Chile and one in Venezuela.

TT was associated with substantial, but heterogeneous reductions on parasite-related outcomes such as positive serology (9 studies, OR $0.21,95 \% \mathrm{Cl} 0.10$ to $0.44, \mathrm{I}^{2}=76 \%$ ), positive PCR ( 2 studies, OR $0.50,95 \% \mathrm{Cl} 0.27$ to $0.92,12=0 \%$ ), positive xenodiagnosis after treatment ( 6 studies, OR $0.35,95 \% \mathrm{Cl} 0.14$ to $0.86, \mathrm{I}^{2}=79 \%$ ), or reduction on antibody titres ( 3 studies, SMD $-0.56,95 \% \mathrm{Cl}-0.89$ to $-0.23, \mathrm{I}^{2}=28 \%$ ). Efficacy data on patient-related outcomes was largely from non-RCTs. TT with nitroderivatives was associated with potentially important, but imprecise and inconsistent reductions in progression of CCC ( 4 studies, 106 events, OR $0.74,95 \% \mathrm{Cl} 0.32$ to $1.73,12=66 \%$ ) and mortality after TT ( 6 studies, 99 events, OR $0.55,95 \% \mathrm{Cl} 0.26$ to 1.14, $\mathrm{I}^{2}=48 \%$ ). The overall median incidence of any severe side effects among 1475 individuals from five studies exposed to TT was $2.7 \%$, and the overall discontinuation of this two-month therapy in RCTs (5 studies, 134 events) was $20.5 \%$ (versus $4.3 \%$ among controls) and $10.4 \%$ in other five studies (125 events).

\section{Authors' conclusions}

Despite the evidence that TT reduced parasite-related outcomes, the low quality and inconsistency of the data for patient-important outcomes must be treated with caution. More geographically diverse RCTs testing newer forms of TT are warranted in order to 1. estimate efficacy more precisely, 2. explore factors potentially responsible for the heterogeneity of results and 3. increase knowledge on the efficacy/ tolerance balance of conventional TT.

\section{PLAIN LANGUAGE SUMMARY}

\section{Drugs against parasites for prevention of Chagas heart disease}

\section{Background}

Chagas disease is a form of heart disease that develops after decades of infection with a parasite called Trypanosoma cruzi. In addition to avoiding transmission of the parasites (through contact with insects in rural areas of many central and south American countries, blood transfusion, organ transplants from infected individuals or vertical transmission to newborns), one of the actions for prevention of Chagas disease is treating the estimated seven to 12 million infected individuals with medications against the parasites (trypanocidal therapy, or TT for short).

Despite the enthusiasm for using TT, there are limitations including uncertainty on its efficacy, poor tolerance and limited production of the conventional drugs. This review presents data from the studies evaluating the impact of TT on the tests looking at the presence of the parasites, the outcome of the infected individual and the tolerance to this short term (i.e. two to three months) treatment.

\section{Study characteristics}

We searched scientific databases for studies comparing TT versus a placebo (an inactive or pretend treatment) or no treatment in people with Trypanosoma cruzi infection. The search is current to February 2014.

\section{Key results}

We identified 13 studies comparing the outcomes of 4229 people after receiving TT or placebo. Five of these studies were from Argentina, five from Brazil, one from Venezuela, one from Chile and one from Bolivia.

Receiving TT was associated with a $50 \%$ to $90 \%$ smaller chance of having circulating antibodies or parasitic material, as compared with nontreated people. However, the results on progression towards Chagas disease or death indicate smaller benefits. Furthermore, the results were also statistically inconclusive, did not rule out potential harm and had substantial variation across studies conducted in different countries or testing different drugs. About one in five individuals treated abandoned the treatment and one in 40 treated individuals had a severe reaction (needing hospitalisation, additional treatments or interruption of this treatment).

We conclude that although TT may reduce the progression of Chagas disease, better quality studies are warranted before its use can be generally recommended for chronically infected individuals. New data should bring more certainty of the efficacy of TT and provide a precise evaluation of the balance between benefits and harms. Because of the variations across studies, these studies should include populations from more regions and test newer drugs. 


\section{Quality of the evidence}

Only $25 \%$ of these data came from good-quality studies. Although most studies were published since 2000 , all studies tested drugs developed in the 1960s. 


\section{SUMMARY OF FINDINGS}

Summary of findings for the main comparison. Nitroderivatives for chronic asymptomatic Trypanosoma cruzi infection

Nitroderivatives for chronic asymptomatic Trypanosoma cruzi infection

Patient or population: people with chronic asymptomatic Trypanosoma cruzi infection Intervention: nitroderivatives

\begin{tabular}{|c|c|c|c|c|c|c|}
\hline \multirow[t]{3}{*}{ Outcomes } & \multicolumn{2}{|c|}{ Illustrative comparative risks ${ }^{\star}(95 \% \mathrm{Cl})$} & \multirow{3}{*}{$\begin{array}{l}\text { Relative ef- } \\
\text { fect } \\
(95 \% \mathrm{Cl})\end{array}$} & \multirow{3}{*}{$\begin{array}{l}\text { No of partici- } \\
\text { pants } \\
\text { (studies) }\end{array}$} & \multirow{3}{*}{$\begin{array}{l}\text { Quality of the } \\
\text { evidence } \\
\text { (GRADE) }\end{array}$} & \multirow[t]{3}{*}{ Comments } \\
\hline & Assumed risk & Corresponding risk & & & & \\
\hline & Control & Nitroderivatives & & & & \\
\hline \multirow{4}{*}{$\begin{array}{l}\text { Positive serology: RCT data - nitroderiva- } \\
\text { tives } \\
\text { Conventional serology, AT and F29 ELISA tech- } \\
\text { niques }\end{array}$} & \multicolumn{2}{|c|}{ Study population } & \multirow{4}{*}{$\begin{array}{l}\text { OR } \mathbf{0 . 1 2} \\
\text { (0.03 to } 0.42 \text { ) }\end{array}$} & \multirow{4}{*}{$\begin{array}{l}524 \\
\text { (3 studies) }\end{array}$} & \multirow{4}{*}{$\begin{array}{l}\oplus \oplus \oplus \ominus \\
\text { moderate }\end{array}$} & \multirow[t]{4}{*}{-} \\
\hline & 793 per 1000 & $\begin{array}{l}\mathbf{3 1 5} \text { per } \mathbf{1 0 0 0} \\
\text { (103 to } 617)\end{array}$ & & & & \\
\hline & \multicolumn{2}{|l|}{ Moderate } & & & & \\
\hline & 824 per 1000 & $\begin{array}{l}\mathbf{3 6 0} \text { per } \mathbf{1 0 0 0} \\
\text { (123 to } 663)\end{array}$ & & & & \\
\hline \multirow{4}{*}{$\begin{array}{l}\text { Positive PCR: RCT data - benznidazole- Chil- } \\
\text { dren } \\
\text { PCR }\end{array}$} & \multicolumn{2}{|c|}{ Study population } & \multirow{4}{*}{$\begin{array}{l}\text { OR } \mathbf{0 . 5 1} \\
(0.25 \text { to } 1.04)\end{array}$} & \multirow{4}{*}{$\begin{array}{l}129 \\
\text { (1 study) }\end{array}$} & \multirow{4}{*}{$\begin{array}{l}\oplus \oplus \oplus \ominus \\
\text { moderate }\end{array}$} & \multirow[t]{4}{*}{-} \\
\hline & 523 per 1000 & $\begin{array}{l}\mathbf{3 5 9} \text { per } \mathbf{1 0 0 0} \\
\text { (215 to } 533)\end{array}$ & & & & \\
\hline & \multicolumn{2}{|l|}{ Moderate } & & & & \\
\hline & 523 per 1000 & $\begin{array}{l}\mathbf{3 5 9} \text { per } \mathbf{1 0 0 0} \\
\text { (215 to } 533)\end{array}$ & & & & \\
\hline \multirow{4}{*}{$\begin{array}{l}\text { Positive xenodiagnosis: all populations - RCT } \\
\text { data - nitroderivatives } \\
\text { Xenodiagnosis }\end{array}$} & \multicolumn{2}{|c|}{ Study population } & \multirow{4}{*}{$\begin{array}{l}\text { OR } \mathbf{0 . 0 9} \\
\text { (0.04 to } 0.18)\end{array}$} & \multirow{4}{*}{$\begin{array}{l}366 \\
\text { (2 studies) }\end{array}$} & \multirow{4}{*}{$\begin{array}{l}\oplus \oplus \oplus \oplus \\
\text { high }\end{array}$} & \multirow[t]{4}{*}{-} \\
\hline & 381 per 1000 & $\begin{array}{l}53 \text { per } 1000 \\
(24 \text { to } 100)\end{array}$ & & & & \\
\hline & \multicolumn{2}{|l|}{ Moderate } & & & & \\
\hline & 387 per 1000 & 54 per 1000 & & & & \\
\hline
\end{tabular}




\begin{tabular}{|c|c|c|c|c|}
\hline $\begin{array}{l}\text { Mean reduction of antibodies titres: all pop- } \\
\text { ulations, all tested drugs } \\
\text { Mean change of antibodies }\end{array}$ & $\begin{array}{l}\text { The mean reduction of anti- } \\
\text { bodies titres: all populations, } \\
\text { all tested drugs in the inter- } \\
\text { vention groups was } \\
\mathbf{0 . 5 6} \text { standard deviations } \\
\text { lower } \\
\text { ( } 0.89 \text { to } 0.23 \text { lower) }\end{array}$ & $\begin{array}{l}225 \\
\text { (3 studies) }\end{array}$ & $\begin{array}{l}\oplus \oplus \ominus \ominus \\
\text { low }\end{array}$ & $\begin{array}{l}\text { SMD }-0.56 \\
(-0.89 \text { to }-0.23)\end{array}$ \\
\hline
\end{tabular}

*The basis for the assumed risk (e.g. the median control group risk across studies) is provided in footnotes. The corresponding risk (and its $95 \%$ confidence interval) is based on the assumed risk in the comparison group and the relative effect of the intervention (and its $95 \% \mathrm{Cl}$ ).

AT: antitrypsin; Cl: confidence interval; ELISA: enzyme-linked immunosorbent assay; OR: odds ratio; PCR: polymerase chain reaction; RCT: randomised controlled trial; SMD: standardised mean difference.

GRADE Working Group grades of evidence

High quality: Further research is very unlikely to change our confidence in the estimate of effect.

Moderate quality: Further research is likely to have an important impact on our confidence in the estimate of effect and may change the estimate.

Low quality: Further research is very likely to have an important impact on our confidence in the estimate of effect and is likely to change the estimate.

Very low quality: We are very uncertain about the estimate.

Summary of findings 2. Nitroderivatives for chronic asymptomatic Trypanosoma cruzi infection

Nitroderivatives for chronic asymptomatic Trypanosoma cruzi infection

Patient or population: people with chronic asymptomatic Trypanosoma cruzi infection Intervention: nitroderivatives

\begin{tabular}{|c|c|c|c|c|c|}
\hline \multirow[t]{2}{*}{ Outcomes } & \multicolumn{2}{|c|}{ Illustrative comparative risks* $(95 \% \mathrm{CI})$} & \multirow{2}{*}{$\begin{array}{l}\text { Relative effect } \\
(95 \% \mathrm{CI})\end{array}$} & \multirow{2}{*}{$\begin{array}{l}\text { No of partici- } \\
\text { pants } \\
\text { (studies) }\end{array}$} & \multirow{2}{*}{$\begin{array}{l}\text { Quality of the } \\
\text { evidence } \\
\text { (GRADE) }\end{array}$} \\
\hline & Assumed risk & Corresponding risk & & & \\
\hline \multirow{4}{*}{$\begin{array}{l}\text { ECG Abnormalities - RCT data - benznida- } \\
\text { zole }\end{array}$} & \multicolumn{2}{|c|}{ Study population } & \multirow{4}{*}{$\begin{array}{l}\text { OR } 0.41 \\
\text { (0.07 to } 2.31)\end{array}$} & \multirow{4}{*}{$\begin{array}{l}235 \\
\text { ( } 2 \text { studies) }\end{array}$} & \multirow{4}{*}{$\begin{array}{l}\oplus \oplus \ominus \ominus \\
\text { low }\end{array}$} \\
\hline & 43 per 1000 & $\begin{array}{l}18 \text { per } 1000 \\
\text { (3 to } 94)\end{array}$ & & & \\
\hline & \multicolumn{2}{|l|}{ Moderate } & & & \\
\hline & 41 per 1000 & 17 per 1000 & & & \\
\hline
\end{tabular}




\begin{tabular}{|c|c|c|c|c|c|}
\hline \multirow{5}{*}{ 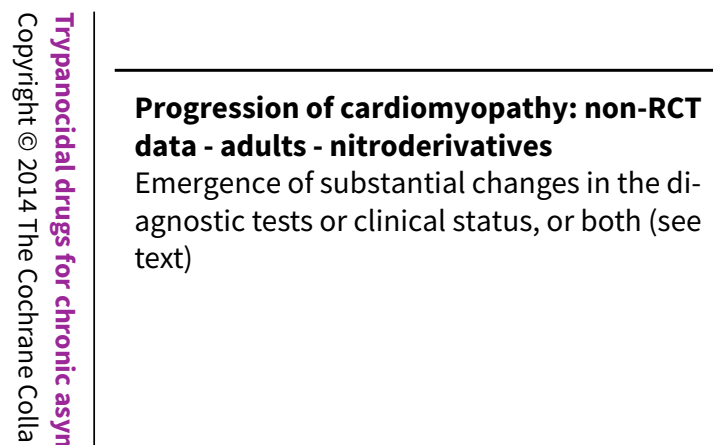 } & \multicolumn{5}{|c|}{ (3 to 90$)$} \\
\hline & \multicolumn{2}{|c|}{ Study population } & \multirow{4}{*}{$\begin{array}{l}\text { OR } \mathbf{0 . 7 4} \\
\text { (0.32 to } 1.73)\end{array}$} & \multirow{4}{*}{$\begin{array}{l}986 \\
\text { (4 studies) }\end{array}$} & \multirow{4}{*}{$\begin{array}{l}\oplus \ominus \ominus \ominus \\
\text { very low }\end{array}$} \\
\hline & 118 per 1000 & $\begin{array}{l}90 \text { per } 1000 \\
\text { (41 to } 187 \text { ) }\end{array}$ & & & \\
\hline & \multicolumn{2}{|l|}{ Moderate } & & & \\
\hline & 116 per 1000 & $\begin{array}{l}89 \text { per } 1000 \\
(40 \text { to } 185)\end{array}$ & & & \\
\hline \multirow{4}{*}{$\begin{array}{l}\text { Mortality: non-RCT data - adults - ni- } \\
\text { troderivatives } \\
\text { All-cause mortality }\end{array}$} & \multicolumn{2}{|c|}{ Study population } & \multirow{4}{*}{$\begin{array}{l}\text { OR } \mathbf{0 . 5 5} \\
(0.26 \text { to } 1.14)\end{array}$} & \multirow{4}{*}{$\begin{array}{l}3396 \\
\text { (6 studies) }\end{array}$} & \multirow{4}{*}{$\begin{array}{l}\oplus \odot \Theta \odot \\
\text { very low }\end{array}$} \\
\hline & 44 per 1000 & $\begin{array}{l}\mathbf{2 5} \text { per } \mathbf{1 0 0 0} \\
(12 \text { to } 50)\end{array}$ & & & \\
\hline & \multicolumn{2}{|l|}{ Moderate } & & & \\
\hline & 55 per 1000 & $\begin{array}{l}31 \text { per } 1000 \\
\text { (15 to } 62)\end{array}$ & & & \\
\hline \multicolumn{6}{|c|}{$\begin{array}{l}{ }^{*} \text { The basis for the assumed risk (e.g. the median control group risk across studies) is provided in footnotes. The corresponding risk (and its } 95 \% \text { confidence interval) is } \\
\text { based on the assumed risk in the comparison group and the relative effect of the intervention (and its } 95 \% \mathrm{CI} \text { ). } \\
\text { Cl: confidence interval; ECG: electrocardiogram; OR: odds ratio; RCT: randomised controlled trial. }\end{array}$} \\
\hline \multicolumn{6}{|c|}{$\begin{array}{l}\text { GRADE Working Group grades of evidence } \\
\text { High quality: Further research is very unlikely to change our confidence in the estimate of effect. } \\
\text { Moderate quality: Further research is likely to have an important impact on our confidence in the estimate of effect and may change the estimate. } \\
\text { Low quality: Further research is very likely to have an important impact on our confidence in the estimate of effect and is likely to change the estimate. } \\
\text { Very low quality: We are very uncertain about the estimate. }\end{array}$} \\
\hline
\end{tabular}




\section{B A C K G R O U N D}

This review updates a previously published version (Villar 2002). Chagas disease, a condition described more than one hundred years ago (Chagas 1909), is the result of human infection by Trypanosoma cruzi. Most commonly, humans acquire this parasite through contact with insects of the reduviidae species living close to wild mammals and domestic animals around or inside poorly built houses in rural areas of Latin America (WHO 2002). Chagas disease remains a public health threat for 21 Latin American countries, where seven to 12 million people are estimated to be infected and 28 million people remain at high risk (Grupo de trabajo científico OMS 2007). The region carries most of the burden of Chagas disease (99.8\%), accounting for at least 662,000 disability-adjusted life years lost (Hotez 2008).

Migration from rural areas to large urban centres within Latin America and more recently to more developed nations has spread this public health threat. The number of infected individuals living in the USA has been estimated as 300,000 (Bern 2009), with 80,000 additional cases in Europe (about two-thirds in Spain) (WHO 2010). This population migratory dynamics, along with the risk of infection to receptors of blood or solid-organ donations, or from infected pregnant women to their children, is increasingly making Chagas disease a global problem (Coura 2010).

\section{Description of the condition}

Primary acute $T$. cruzi infection is seldom clinically evident. Serology, and increasingly polymerase chain reactions (PCR), confirm the diagnosis of chronic infection. For the most part, the burden of Chagas disease comes from the $10 \%$ to $30 \%$ of individuals who develop, after decades of silent infection, chronic chagasic cardiomyopathy (CCC). Clinical suspicion of CCC arises in T. cruzi chronically infected individuals with cardiac rhythm or conduction abnormalities, symptoms of heart failure or embolism originating in dilated hearts (Laranja 1956; Hagar 1991; Coura 2005). Once clinically evident, CCC conveys a much worse prognosis than other forms of dilated cardiomyopathy (Freitas 2005). This review focuses on prevention of CCC, rather than other complications of T. cruzi infection (e.g. those in the central nervous system or the gastrointestinal (GI) tract).

Prevention of CCC among infected individuals (i.e. host-based control) was for many years considered a difficult goal to achieve. Based on that perspective, efforts from public health authorities focused on preventing infection among individuals at risk (i.e. vector-based control). This policy led to the interruption of the transmission of $T$. cruzi infection by Triatoma infestans, the most important vector in southern South America in the early 1990s (Moncayo 2003). However, sustaining and extending this achievement to the Andean and Central American countries was limited by logistical, political and biological barriers (Guhl 2005; Dias 2009). As a result, it has been recognised that dissemination, emergence and re-emergence all hinder elimination of $T$. cruzi infection, now seen as a more elusive goal (WHO 2009).

\section{Description of the intervention}

The difficulties found for vector-based control paralleled a renewed enthusiasm for improving the host-based control. The first and more logical intervention of this control strategy is treating chronically infected individuals with trypanocidal therapy (TT).
Before the 1990s, scepticism was associated with the idea of offering TT to people at risk of CCC for a number of reasons: uncertainty on the pathogenic role of parasitism; low sensitivity and responsiveness of tools to evaluate change in parasiterelated outcomes (i.e. xenodiagnosis and conventional serology) and the need for very large person-years of follow-up to record patient-important outcomes. Finally, use of conventional TT drugs (developed in the 1960s with no substantial innovations afterwards) was associated with uncertain efficacy and a relatively high incidence of side effects.

Since the 2000s, there has been a growing interest in TT. On the one hand, it was argued that focusing on vector-based control left the risk of CCC in the population already infected uncovered (Villar 2001). On the other hand, scientific findings began to overcome the logistic or methodological barriers regarding the use of TT. First, studies incorporating deoxyribonucleic acid (DNA) hybridisation techniques showed that circulating parasitic load and parasitic DNA/antigens in tissues correlated well with the degree of inflammation, and that no organ damage occurred in the absence of these lesions (Jones 1993; Marinho 1999; Higuchi 2003). In addition, several investigators showed in experimental models of T. cruzi infection that reduction of parasite load with TT led to significantly less myocardial damage (Andrade 1991; García 2005; Bahia 2012). Finally, investigators evaluated the impact of TT on clinically relevant outcomes among individuals with chronic infection through comparison with untreated controls (Andrade 1996; Sosa-Estani 1998; Viotti 2006*).

There is consensus that all patients with primary acute Chagas disease or reactivation of chronic infection (e.g. after immunosuppression, human immunodeficiency virus (HIV) coinfection or following organ transplantation) should receive TT with nitroderivatives. The recommended dose is usually 5 to $7 \mathrm{mg} / \mathrm{kg} /$ day, divided in two or three times daily, for 30 to 90 days. However, no consensus has been achieved regarding TT for chronically infected people. The more frequently reported side effects are skin reactions and neuropathy, which occasionally forces interruption of treatment.

The first randomised, placebo-controlled trials addressing the issue included children (i.e. more responsive individuals) and recorded more sensitive or responsive diagnostic methods than previously (e.g. antitrypsin enzyme-linked immunosorbent assay (AT ELISA) and, more recently, PCR-based detection of circulating parasite materials). Investigators tested not only the conventional TT nitroderivative drugs available since the 1970 s (i.e. nifurtimox (NFTMX) and benznidazole (BZD)) but also clinically approved drugs with possible trypanocidal activity such as allopurinol (ALLOP) or itraconazole (ITRA) (Gianella 1994; Apt 1998; Gallerano 2001).

\section{Why it is important to do this review}

This scientific progress finally translated into a recommendation for treating children with recent chronic infection (Sosa 1999; Grupo de trabajo científico OMS 2007). However, apart from this indication, the use of TT is still controversial for people in the chronic phase of Chagas disease. Systematic reviews have highlighted the remaining uncertainty regarding the efficacy of TT on chronically infected populations (Villar 2002; Reyes 2005; Bern 2009; Perez-Molina 2009). In fact, the First Latin American Guidelines for the Diagnosis and Treatment of Chronic Chagas 
Cardiomyopathy also did not make any recommendations for TT in people with the indeterminate or the clinically overt CCC. In an attempt to overcome those limitations, new, large randomised trials testing the impact of TT in this population are underway (Prado 2008; López 2009; Marin-Neto 2009). New observational studies (Fabbro 2000**; Lauria-Pires 2000), and new reports from previous studies (Galvao 2003; Andrade 2004; Viotti 2006*), have also emerged since the publication of the first version of this review in 2002. Therefore, we are updating this work.

\section{O B JECTIVES}

To systematically search, appraise, identify and extract data from eligible studies comparing the outcome of cohorts of seropositive individuals to T. cruzi exposed to TT versus placebo or no treatment.

\section{METHODS}

\section{Criteria for considering studies for this review}

\section{Types of studies}

We included data from reports of studies on the topic of interest of two types:

- randomised controlled trials (RCTs) allocating participants to one or more forms of TT with an experimental arm receiving placebo or no treatment;

- observational studies comparing the outcomes of people who received TT versus other people derived from the same population setting with no exposure to TT, as long as they reported the incidence of patient-important outcomes (see Primary outcomes; Secondary outcomes) after at least four years of follow-up to both study groups.

\section{Types of participants}

People with chronic $T$. cruzi infection, as diagnosed with positive serology by at least two of the following techniques: ELISA, indirect haemaglutination (IHA) or indirect immunofluorescence (IIF) without clinically evident (i.e. symptomatic) CCC. For studies without clear distinction of the clinical status of the infected population included, we planned to interpret the information from the description of the population (outpatients not receiving any supportive treatment), or clarify this issue with the authors, aiming at including studies with at least $80 \%$ of the population free of symptomatic CCC.

\section{Types of interventions}

We considered TT as any oral treatment offered for at least 30 days to study participants because of their T. cruzi serology status, intended to reduce or suppress the parasitic load, as stated by the authors, and compared against a placebo or a control group.

We divided the TT offered to study participants into:

- nitroimidazolic derivatives, such as NFTMX and BZD;

- non-nitroimidazolic derivatives, including ALLOP, ITRA and other drugs meeting the criteria for our definition of TT.

\section{Types of outcome measures}

We included studies when reporting data on outcomes of two types:
- parasite-related outcomes: they included positive serology (dichotomous); mean reduction of antibodies titres (continuous), positive xenodiagnosis (dichotomous), or positive PCR (dichotomous) after receiving treatment;

- patient-related outcomes: they were divided into:

- efficacy outcomes, such as all-cause mortality, or significant progression of CCC. We recorded data on sudden death; mortality or hospitalisation due to cardiovascular causes as long as the study source described a treatment-blinded outcome adjudication process. We defined "significant progression of CCC" was defined as the emergence of substantial changes in the diagnostic tests or clinical status (requiring hospitalisation, implantation of cardiac devices or causing death), or both diagnostic tests and clinical status. For participants with normal electrocardiogram (ECG) at baseline, progression was defined as developing two new ECG abnormalities, or a single ECG abnormality that normally requires medical treatment (e.g. ventricular tachycardia, atrial fibrillation or flutter, complete A-V block). For studies following Kuschnir's classification criteria (Kuschnir 1985), we recorded as progression a change of at least two stages during the follow-up period. That is, infected individuals with a normal ECG at baseline (stage 0) who developed either cardiomegaly (as documented through any imaging method) or symptoms of heart failure (stage II), and infected asymptomatic individuals with abnormal ECGs at baseline (stage I) who develop symptoms of heart failure (stage III). All deaths during follow-up were also recorded as significant progression of CCC.

- Safety-related outcomes, defined as any symptom potentially related with TT that authors decided to record in treated groups. These outcomes were categorised as mildto-moderate (e.g. headache, nausea, dyspepsia, pruritus) or severe, including conditions that authors included in this category, described as requiring discontinuation of therapy or hospitalisation (e.g. seizures, fever, StevensJohnson syndrome or severe dermatitis, leukopenia or toxic hepatitis).

We recorded any safety-related outcome of interest in placebocontrolled RCTs. In contrast, such outcome data from other studies in this review included only severe safety-related outcomes (as stated by the authors, related with hospitalisation, or causing treatment withdrawal).

Xenodiagnosis is a test for parasite infection, in which the natural vector of $T$. cruzi infection is used as a growth medium for seeking parasites in the human individuals tested. In the typical procedure, nymphs of laboratory-bred insects of reduviiduae species (not carrying any parasites) are covered in a Petri's box and attached to the forearm of the individual being tested. These nymphs are allowed to feed on the individual's blood for 48 hours, before removal of the Petri's box. One month later, the insects have grown to an adult stage. They are sacrificed in order to look for parasites in their intestinal contents. If parasites are found in the adult reduviidae insects, the patient is deemed to have a "positive xenodiagnosis".

\section{Primary outcomes}

1. Any patient-related outcomes regarding efficacy. 


\section{Secondary outcomes}

1. All parasite-related outcomes from RCTs.

2. Patient-related outcomes regarding safety considered severe.

3. Patient-related outcomes regarding safety of mild-to-moderate relevance (from RCTs).

4. All parasite-related outcomes recorded in non-RCTs.

\section{Search methods for identification of studies}

\section{Electronic searches}

Searches were originally run for this review in 2000 (Villar 2002). They were updated in May 2010 (without an RCT filter, Appendix 1) and again in February 2014 (with an RCT filter, Appendix 2). We searched:

- Cochrane Central Register of Controlled Trials (CENTRAL) (Issue 1, 2014);

- MEDLINE (Ovid, 1950 to April week 4 2010);

- EMBASE (Ovid, 1980 to 2010 week 17);

- LILACS (1982 to 6 May 2012).

In the 2014 search, the RCT filter for MEDLINE was the Cochrane sensitivity-maximising RCT filter, and for EMBASE, terms as recommended in the Cochrane Handbook for Systematic Reviews of Interventions have been applied (Lefebvre 2011).

\section{Searching other resources}

Additional searches for relevant material included a Google search (the first 100 hits, in order of relevance, when typing 'Chagas treatment'); handsearching of references of the narrative and systematic reviews retrieved with the electronic search, and questions to experts in the field.

\section{Data collection and analysis}

The process for identifying relevant material followed a two-step process.
Step one consisted of a pre-selection after screening titles and abstracts (or full papers when the abstract was not available) of all retrieved citations in the electronic search. A reference was preselected material when it referred to:

1. human participants (rather than animal studies);

2. therapy (rather than diagnosis, pathophysiology, etc.) of Chagas disease;

3. use of TT (rather than other forms of treatment).

Two review authors (MRP and JGP) attempted step one in parallel. A reference was pre-selected when at least one of the review authors considered it potentially relevant for inclusion.

Step two consisted of a further examination of all pre-selected material by having both review authors assessing full-text material and deciding on inclusion. We resolved discrepancies by consensus, or called a referee, when needed. We computed the Kappa statistics for agreement on inclusion with the Epi Info 6.04 software package (Centers for Disease Control and Prevention (CDC), USA).

We designed a form in order to collect information from included studies. It covered general characteristics of the studies, information on demographics, disease, intervention, follow-up, outcomes and study quality features. Three review authors (MRP, JGP and OLC) independently extracted the information from each study, resolving any differences by discussion with the leading review author until reaching consensus.

Assessment of risk of bias of included studies applied different criteria for RCTs than the non-RCTs. We followed a pre-defined, itemised checklist of risk of bias, that three review authors independently judged as present or absent (see Figure 1). For RCTs, review authors checked the report of methods of randomisation, blinding, loss to follow-up, the rate of participants completing the planned follow-up period (considering acceptable if over 90\%), and the presence of intention-to-treat analysis. We categorised the risk of bias of RCTs as low if zero to two features were present, intermediate if three or four features were present or high when all five features were present. 
Figure 1. Quality assessment of the studies other than RCTs included.

\begin{tabular}{|c|c|c|c|c|c|c|c|}
\hline Study & $\begin{array}{c}\text { Sampling/selection } \\
\text { process } \\
\text { described? }\end{array}$ & \begin{tabular}{|c|} 
Eligibility \\
criteria \\
described?
\end{tabular} & $\begin{array}{c}\text { Blinded } \\
\text { outcome } \\
\text { Assessment? }\end{array}$ & \begin{tabular}{|c|} 
Baseline \\
group \\
comparison?
\end{tabular} & $\begin{array}{c}\text { Managing of } \\
\text { confounding } \\
\text { reported? }\end{array}$ & $\begin{array}{l}\text { Report of } \\
\text { adjusted } \\
\text { results? }\end{array}$ & $\begin{array}{l}\text { Follow up } \\
\text { rates } \\
\text { described? }\end{array}$ \\
\hline $\begin{array}{l}\text { Experimental } \\
\text { Apt }\end{array}$ & No & Yes & Yes & No & No & No & $\begin{array}{c}\text { Yes (Up to } 2 \text { months } \\
98.3 \% \text { ) }\end{array}$ \\
\hline Cattlioti & Yes & Yes & No & Yes & No & No & No \\
\hline Silveira/Britto & Yes & Yes & No & No & No & No & No \\
\hline Viotti & Yes & Yes & Yes & Yes & Yes & Yes & Yes $(76.1 \%)$ \\
\hline \multicolumn{8}{|l|}{ Observational } \\
\hline Fabbro & Yes & Yes & No & Yes & Yes & No & Uncertain \\
\hline Gallerano & No & No & No & Yes & Yes & No & $\begin{array}{l}\text { Yes ( } 100 \% \text { up to } 5 \mathrm{y} \text {; } \\
45,9 \% \text { up to } 10 \mathrm{y})\end{array}$ \\
\hline Lauria-Pires & Yes & Yes & Yes & No & No & No & $\begin{array}{l}\text { Yes (up to } 10 \text { years: } \\
75.5 \text { Treated } \\
78.0 \text { Untreated) }\end{array}$ \\
\hline
\end{tabular}

For non-RCTs, our extraction form considered a description of seven items: the sampling/selection of participants as well as the eligibility criteria, blinding status of outcome assessors, comparisons of baseline characteristics of the participants, report of any methods to deal with confounding, report of adjusted results and description of the proportion of participants completing the scheduled follow-up period (considering acceptable if over $80 \%$ ). Based on that form, we considered quality as low if zero to two features were present, intermediate if three to five features were present or high if six or seven features were present.

The data synthesis comprised a description of characteristics of included studies, the items included in the Cochrane quality assessment tool as well as a quantitative synthesis of their outcome data. For the included RCTs, we extracted all outcome data reported. For non-RCT studies, we considered only patientimportant outcomes. Data on parasite-related outcomes from non-RCTs served for exploratory analysis only. Extraction of dichotomous outcomes followed the intention-to-treat principle, where denominators were the number of participants originally allocated to TT. Participants with uncertain outcome (i.e. people lost during follow-up) were considered as having no events. The numbers for continuous outcomes were the numbers of participants with available information.
Summary measures consisted of generating, when appropriate, pooled effect estimates and their 95\% confidence intervals $(\mathrm{Cl})$ of the outcomes of interest. For dichotomous outcomes (e.g. positive serology after treatment), we computed Mantel-Haenszel odds ratios (OR). When available and appropriate, we conducted separate analysis for different outcomes according to categories of interest, including type of studies (RCT data versus other studies), populations (e.g. children or adults) and interventions (i.e. nitroderivative or other drugs). For continuous outcomes, we computed pooled standardised mean differences (SMDs) with their 95\% Cls between treatment groups. Differences within studies resulted from subtracting the mean antibody titres after treatment from the antibody titres at baseline. Variance of the mean differences within studies was inferred using the methodology suggested by Follmann 1992.

We used Review Manager 5 software package to generate pooled effect estimates, using a random-effects model (RevMan 2012). All those estimates included a general statistics for the main effects as well as for the heterogeneity of the data across studies. We considered a statistically significant effect when the $P$ value for the overall $Z$ statistics was less than 0.05 . We judged heterogeneity across studies using the 12 statistic, expressed as percentage.

We ran a meta-regression analysis to explore the relationship between trypanocidal effect and clinical efficacy (in terms of 
parasite-related and patient-related outcomes, respectively). We computed the slope along with their $95 \% \mathrm{Cl}$ using the Stata software package (version 11.2).

We carried out no subgroup or sensitivity analysis due to the small number of RCTs available.

Finally, we used the GRADE profiler software package (V 3.6), in order to assign a level of evidence around the data extracted and to generate pooled estimates and Cls (see Summary of findings for the main comparison; Summary of findings 2).

\section{RES U L T S}

\section{Description of studies}

\section{Results of the search}

The search for the first edition of this review (MEDLINE, EMBASE, the World Health Organization (WHO) database for the Tropical Disease
Research Programme) identified 1306 potentially relevant titles or abstracts. After screening, we assessed 43 of these studies in full for inclusion, and five met the inclusion criteria (Kappa $=0.77$ for inclusion).

The updated search identified 1279 references for screening in May 2010. We considered 101 studies (97 retrieved from databases and four through reference lists or contact with study authors) to be potentially relevant and 30 underwent a more detailed assessment (with the full-length report) for inclusion. We included eight study reports presented in 10 articles (Kappa $=0.84$ for inclusion) and identified one ongoing study (Marin-Neto 2009).

One final updated search in February 2014 identified 282 references for screening and none of these were eligible for inclusion (Figure 2). 
Figure 2. Study flow diagram.

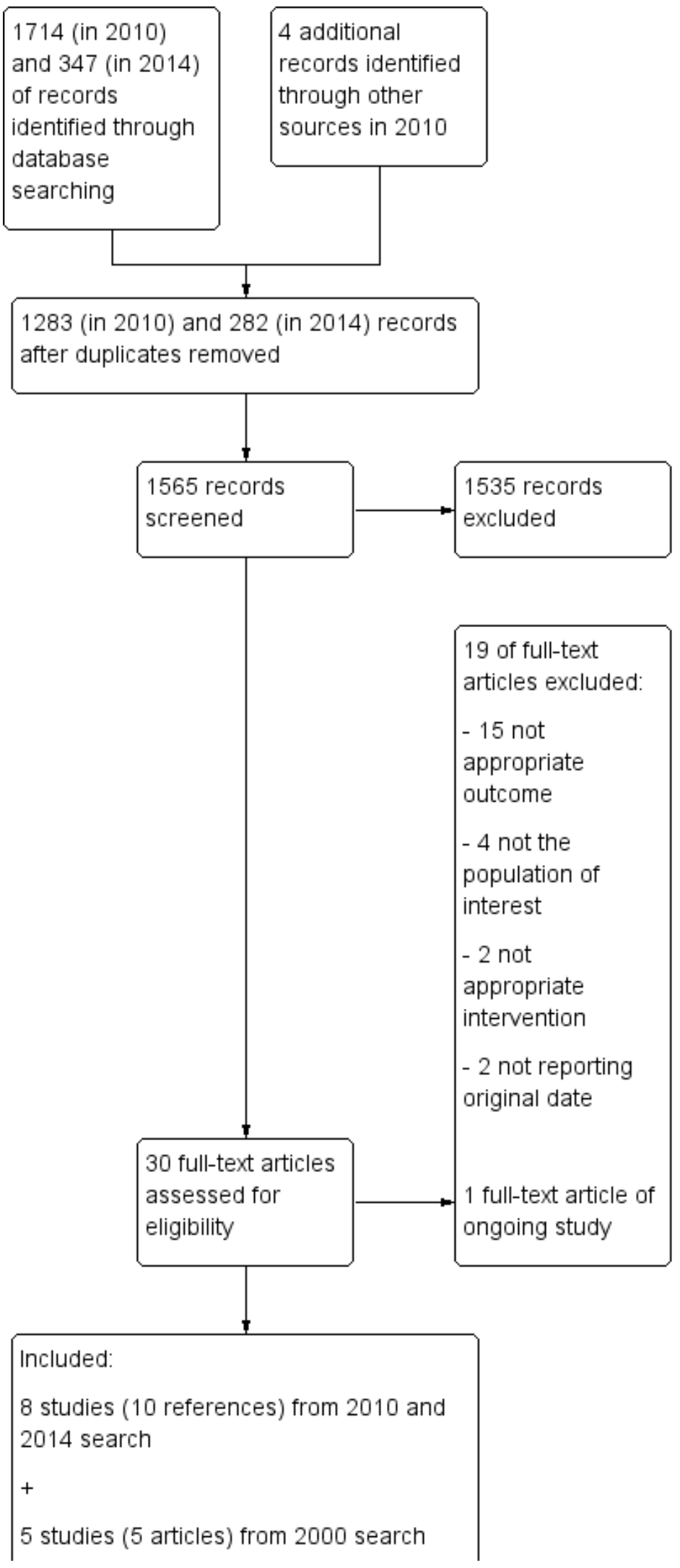


Figure 2. (Continued)

\section{5 studies ( 5 articles) from 2000 search}

Therefore, our review included data from 13 studies described in 15 reports (see Characteristics of included studies table). The reasons for exclusion of studies are described in the Characteristics of excluded studies table.

\section{Included studies}

This review included six RCTs (Gianella 1994; Coura 1997; SosaEstani 1998; Andrade 2004; Rassi 2007; Prado 2008); four nonrandomised experiments (Apt 1998; Silveira 2000*; Catalioti 2001*; Viotti 2006*), and three observational studies (Fabbro 2000**; Gallerano 2000**; Lauria-Pires 2000). Studies were conducted in a variety of South American countries, five of them from Brazil, five from Argentina, one from Chile, one from Bolivia and one from Venezuela.

Altogether, these studies included 4229 participants, 1883 people receiving different forms of TT (BZD 1082 people, NFTMX 210 people, ALLOP 456 people and itraconazole 135 people) and 2346 people in control groups ( 779 receiving placebos and 1567 receiving no treatment with TT). Data from RCTs accounted for $26 \%$ of the participants in the included studies. The appended Figure 3 summarises the main features of the included studies.

\section{Figure 3. Main characteristics of the included studies.}

\begin{tabular}{|c|c|c|c|c|c|c|c|c|c|}
\hline \multirow{3}{*}{$1^{\text {st }}$ author year, country } & \multirow{3}{*}{$\begin{array}{c}\text { Type of } \\
\text { participants } \\
\text { (totaln=) }\end{array}$} & \multicolumn{6}{|c|}{ Allocated interventions (n) } & \multicolumn{2}{|c|}{ Outcomes considered for this review } \\
\hline & & \multicolumn{4}{|c|}{ Active } & \multicolumn{2}{|c|}{ Control } & \multirow[b]{2}{*}{ Parasite-rekated } & \multirow[b]{2}{*}{ Patient-rekted } \\
\hline & & BZD & $\begin{array}{l}\text { NFTM } \\
\mathrm{x}\end{array}$ & ALLOP & ITRA & PL & UNT & & \\
\hline $\begin{array}{l}\text { RCT's } \\
\text { Andrade(19968:2004)+Galvao2003, Bxazil }\end{array}$ & Childven (129) & 64 & & & & 65 & & $\begin{array}{l}\text { Serology status, } \\
\text { mearn change of } \\
A B s, P C R\end{array}$ & ECG status \\
\hline Gianella 1994, Bolivia & Adults (40) & & & 18 & & 22 & & $\begin{array}{l}\text { Xenodiagnosis, } \\
\text { mearn change of } \\
\mathrm{ABs}\end{array}$ & Side effects \\
\hline Prado 2008, Axgentina & Adults (709) | & 352 & & & & 357 & & & Side effects \\
\hline Rassi 2007, Brazil & Adults (35) & & & 23 & & 12 & & $\begin{array}{l}\text { Xenodiagnosis, } \\
\text { Serology status }\end{array}$ & Side effects \\
\hline Rodrigues Couxa 1997, Bxazil & Adults (TT) & 26 & 27 & & & 24 & & $\begin{array}{l}\text { Xenodiagnosis, } \\
\text { serology status }\end{array}$ & \\
\hline Sosa-Estani 1998, Axgentina & Children (106) & 55 & & & & 51 & & $\begin{array}{l}\text { Xenodiagnosis, } \\
\text { serology status, } \\
\text { mean change of } \\
\mathrm{ABs}\end{array}$ & ECG status, Side effects \\
\hline \multicolumn{10}{|l|}{ Non-randomized experiments } \\
\hline Apt,1998, Chile & Adults (404) & & & 104 & 135 & 165 & & Xenodiagnosis & Side effects \\
\hline Catalioti, 2001, Venezuela & Adults (539) & 74 & & & & & 465 & & Mortality \\
\hline Silveira $2000+$ Britto 2001, Bxazil & Adults (98) & 34 & 25 & & & & 39 & $\begin{array}{l}\text { Xenodiagnosis, } \\
\text { serology status*, } \\
\text { PCR }\end{array}$ & $\begin{array}{l}\text { Progression of } \mathrm{CCC} \text {, } \\
\text { Death }\end{array}$ \\
\hline Viotti, 2006 Afgentina & Adults (598) & 294 & & & & & 304 & Serology status* & $\begin{array}{l}\text { Side effects, Progression } \\
\text { of CCC, Mortality }\end{array}$ \\
\hline \multicolumn{10}{|l|}{ Observational studies } \\
\hline Fabro, 2000, Axgentina & Adults (200) & 36 & 34 & & & & 130 & Serology status * & $\begin{array}{l}\text { Progxession of } \mathrm{CCC} \\
\text { Mortality }\end{array}$ \\
\hline Gallexano, 2000 , Axgentina & Adults (1203) & 130 & 96 & 309 & & & 668 & Sexology status * & $\begin{array}{l}\text { Side effects Progxession of } \\
\mathrm{CCC} \text {, mortality }\end{array}$ \\
\hline Lauria-Pires, 2000, Bxazil & Adults (91) & 17 & 28 & & & & 46 & Serology status * & $\begin{array}{l}\text { Progression of } \mathrm{CCC} \\
\text { Mortality }\end{array}$ \\
\hline
\end{tabular}

*For exploxatony meta-tegxession analysis

\section{Risk of bias in included studies}

We judged none of the six RCTs as low risk of bias. However, five of these studies had intermediate risk of bias and the remaining study was of high risk of bias. Study authors did not report on the method of randomisation, although all studies reported their outcome assessors (largely parasite-related) as blinded (appended Figure 4). Only one of the other seven studies (four non-randomised experiments and three observational studies) filled criteria to be low risk of bias (Viotti 2006*). The remaining studies were of intermediate risk of bias. As shown in the appended Figure 1, there was little consistency in the presence/absence of these markers of validity, except for the absence of reporting adjusted results in six out of these seven studies. Risk of bias is shown in Figure 5 and Figure 6. 
Figure 4. Quality assessment of randomised controlled trials included.

\begin{tabular}{|l|c|c|c|c|c|}
\hline \multicolumn{1}{|c|}{ References } & $\begin{array}{c}\text { Randomisation } \\
\text { method reported? }\end{array}$ & $\begin{array}{c}\text { Blinded } \\
\text { reported? }\end{array}$ & $\begin{array}{c}\text { Withdrawals/dropouts } \\
\text { reported? }\end{array}$ & $\begin{array}{c}\text { Participants with } \\
\text { complete follow-up } \\
\text { (\%) }\end{array}$ & $\begin{array}{c}\text { Intention to } \\
\text { treat analysis }\end{array}$ \\
\hline Andrade/Galvao & No & Yes & Yes & 77.0 & Yes \\
\hline Gianella & No & Yes & Yes & 75.0 & No \\
\hline Prado & No & Yes & Yes & $100 \ddagger$ & Yes \\
\hline Rassi & No & Yes & Yes & 77.1 & Yes \\
\hline Rodrigues-Coura & No & Yes & Yes & 83.2 & No \\
\hline Sosa-Estani & No & Yes & Yes & 95.2 & No \\
\hline
\end{tabular}

$\ddagger$ For observation of side effects during treatment 
Figure 5. Risk of bias summary: review authors' judgements about each risk of bias item for each included study. ${ }^{\star}$ Non-randomised experiment ${ }^{\star \star}$ Observational study

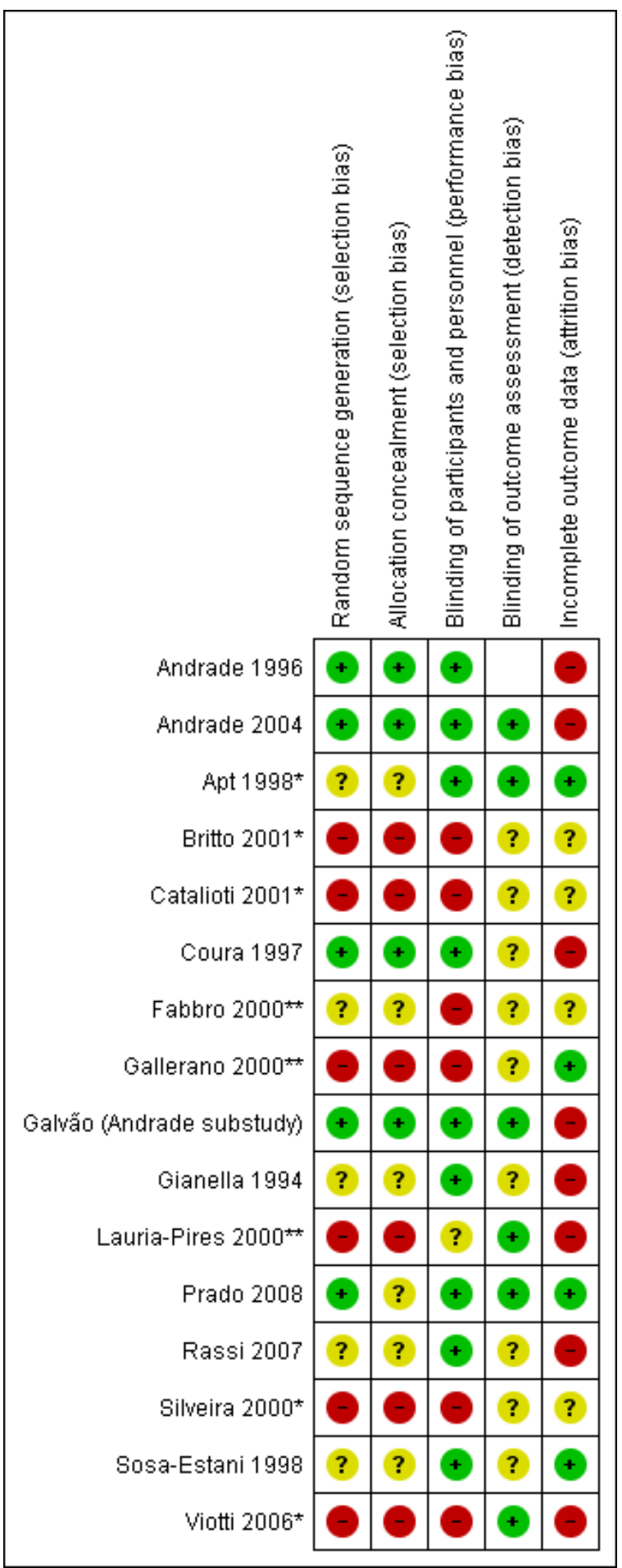


Figure 6. Risk of bias graph: review authors' judgements about each risk of bias item presented as percentages across all included studies.

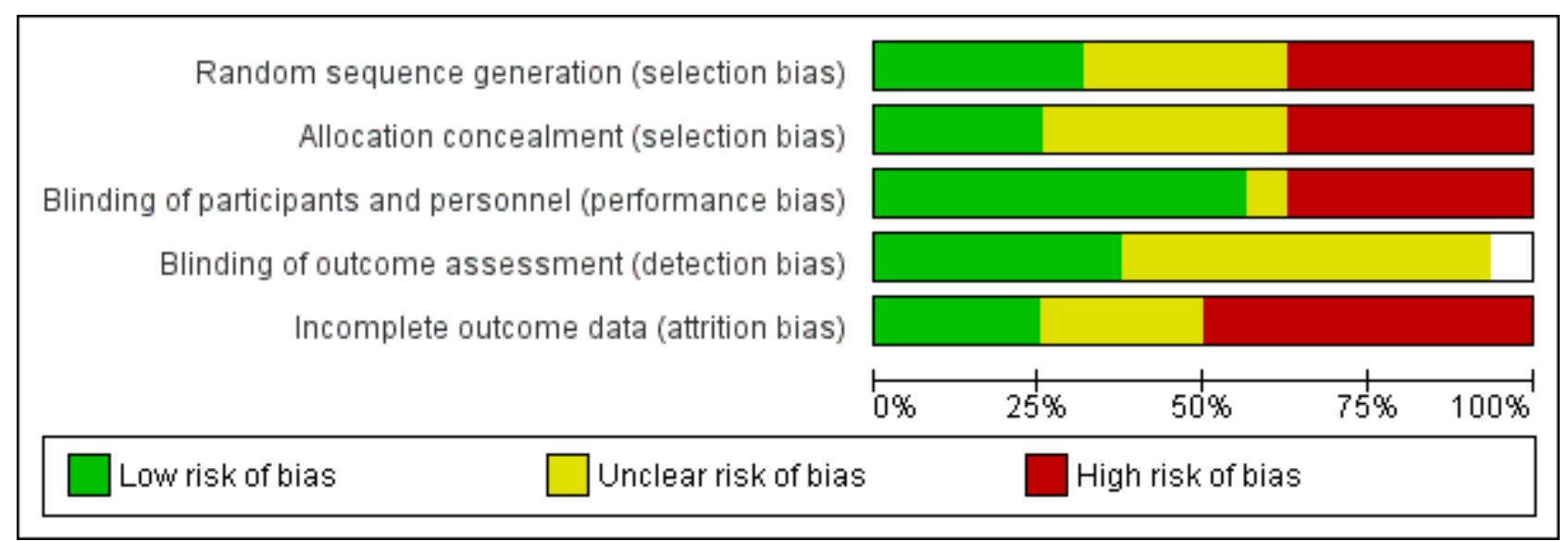

\section{Effects of interventions}

See: Summary of findings for the main comparison Nitroderivatives for chronic asymptomatic Trypanosoma cruzi infection; Summary of findings 2 Nitroderivatives for chronic asymptomatic Trypanosoma cruzi infection

\section{Parasite-related outcomes}

RCT data on positive serology after treatment (four studies, two testing BZD in children, and the other two testing TT in adults, one testing both nitroderivatives, and the other testing ALLOP) differed substantially $(12=76 \%)$. We were not able to estimate the effect in the two studies of adults (no changes in any of the 112 participants included), whereas the studies in children (both using the AT ELISA technique) showed a substantial and significant reduction of the risk of persistence of positive serology (OR $0.12,95 \% \mathrm{Cl} 0.03$ to 0.42 ). The one RCT providing data on conventional serology, AT ELISA and ELISA against the F29 antigen showed substantial variation among serology techniques, with significantly better results with the ELISA technique ( $P$ value $<0.001$ for comparison with either of the other techniques). Data on positive serology recorded in five non-RCTs (all with conventional serology) showed an effect of nitroderivatives in a similar direction and magnitude of the effect (OR $0.34,95 \% \mathrm{Cl} 0.16$ to 0.73$)$, with borderline heterogeneity $\left(\mathrm{I}^{2}=\right.$ $47 \%)$. Analysis 1.1 summarises these data.

Data on positive PCR after treatment (one RCT recording 57 events) suggest that nitroderivatives reduced this risk by half (Analysis $1.2)$, with borderline statistical significance $(P$ value $=0.06)$. Results from one non-RCT also testing nitroderivative drugs showed similar results ( $12=0 \%$ between both studies). If considered together, the effect size (OR $0.50,95 \% \mathrm{Cl} 0.27$ to 0.92 ) reached statistical significance.

Xenodiagnosis is the most frequently recorded of these outcomes (Analysis 1.3). Data from RCTs testing nitroderivatives also showed a sizeable and significant effect (OR $0.09,95 \% \mathrm{Cl} 0.04$ to 0.18 ) with homogeneous results $\left(\mathrm{I}^{2}=0 \%\right)$. The two RCTs testing ALLOP showed a reduction that was both non-significant and homogeneous. Information on the impact of itraconazole comes from a single study (a quasi-randomised experiment) that showed a non-significant reduction (OR $0.42,95 \% \mathrm{Cl} 0.17$ to 1.03 ).
Data from the two RCTs testing BZD in children also showed a significant and homogeneous reduction of the antibody titres. This effect was not observed in the one RCT testing ALLOP in adults that provided similar outcome data (Analysis 1.4).

Taking together, all available sources of information, TT reduced parasite-related outcomes, with substantial heterogeneity, both clinically and statistically. Higher levels of certainty are associated with trials of children receiving BZD, whereas results from other drugs/populations await for more extensive evaluation.

\section{Patient-related outcomes}

\section{Efficacy outcomes (Analysis 2.1, Analysis 2.2)}

The only RCT data available in patient-related outcomes showed a non-significant reduction in the appearance of ECG abnormalities, with seven events out of 235 randomised (two events for BZDtreated children and five events for children receiving placebo), as shown in Analysis 2.1.

Four non-RCTs provided data on progression of CCC (Analysis 2.2), all testing nitroderivatives in adults from Brazil and Argentina. The pooled effect size estimate (analysis based on 106 events, 45 among individuals receiving TT) suggested a non-significant and heterogeneous reduction in the progress of CCC (OR 0.74, $95 \% \mathrm{Cl} 0.32$ to $1.73, \mathrm{I}^{2}=66 \%$ ). Two of these studies show a nonsignificant excess of progression of CCC in TT-treated participants, whereas a single study ( 21 events, $25 \%$ of the weight) showed a significant reduction of this outcome. This study accounted for the heterogeneity of results ( $I^{2}=0 \%$ after removal of that study).

The six non-RCT studies reported all-cause mortality data (total of 126 events), with a non-significant reduction (OR $0.55,95 \% \mathrm{Cl}$ 0.26 to 1.14$)$ with borderline heterogeneity $\left(I^{2}=48 \%\right)$, as shown in Analysis 2.3. Evaluation of nitroderivatives, which accounts for $80 \%$ of the weight (84 events) show similar results (OR $0.66,95 \%$ $\mathrm{Cl} 0.28$ to $1.56,12=49 \%$ ). Four out of the seven results pooled showed an increased risk of mortality (Fabbro 2000**; LauriaPires 2000; Silveira 2000*; Catalioti 2001*), all of them testing nitroderivatives. Two of the studies showing reductions of mortality tested nitroderivatives (Gallerano 2000**; Viotti 2006*), and the remaining result favoured ALLOP over no treatment in terms of 
mortality (42 events, $20 \%$ of the weight, OR $0.28,95 \% \mathrm{Cl} 0.11$ to 0.72).

Overall, data on these patient-related outcomes came from nonRCTs, did not show a significant effect or consistency across studies. Other than intrinsic biases, variations across populations in these studies may explain the heterogeneity. For mortality, most studies (four out of six) showed a relative increase of the risk. For progression of CCC, two of the four studies showed increased risk. Results for populations from Brazil and Venezuela showed increased risk of these events, whereas results from Argentinian studies showed better results.

\section{Safety outcomes (Analysis 3.1 to Analysis 3.9)}

Authors of the included studies reported a number of severe side effects such as toxic hepatitis (6 out of 482), arthritis (10 out of $352)$, peripheral neuropathy (11 out of 482), lymphadenopathy (9 out of 352), oedema (19 out of 352), fever (17 out of 635), severe skin reactions (54 out of 424) and severe GI intolerance ( 6 out of 424) among participants treated with BZD. The median proportion of any severe side effects was $2.7 \%$. For ALLOP-treated participants, authors reported severe skin reactions, fever and severe GI intolerance, with a median proportion of $2.4 \%$. For NFTMX, the median proportion of severe side effects (including polyneuritis, toxic hepatitis, malaise and severe skin reactions) was $6.3 \%$. The overall median proportion including all recorded data was $2.7 \%$.

Mild-to-moderate side effects recorded from RCTs reaching statistical significance ( $P$ value $<0.001$ in all cases) came from the TRAENA trial (352 participants treated with BZD and 357 participants treated with placebo) and consisted of skin reactions, such as pruritus (23.9\% with BZD versus $7.6 \%$ with placebo), mild rash (36.4\% with BZD versus $7.0 \%$ with placebo) and moderate rash where physician prescribed antihistamines $(21.3 \%$ with BZD versus $3.4 \%$ with placebo).

Finally, five RCTs provided data on drug discontinuation, 547 individuals treated with TT (from which $96 \%$ were included in studies testing nitroderivatives) and 509 treated with placebo. The pooled rates were $20.5 \%$ and $4.3 \%$ for TT and placebo, respectively (pooled OR 2.65, 95\% $\mathrm{Cl} 0.4$ to 17.7 ), with substantial heterogeneity $(12=90 \%)$ indicating significantly lower discontinuation rates for children in comparison with adults. The only study showing significant results was the TRAENA trial, where $25.3 \%$ of the 352 participants receiving BZD abandoned this treatment, compared with $2.0 \%$ of participants receiving placebo. Data from the remaining studies indicated an overall discontinuation of TT in $10.6 \%$ of the treated individuals, with substantial variations, ranging from $11.4 \%$ to $31.1 \%$ among individuals receiving nitroderivatives and ranging from $0.7 \%$ to $3.9 \%$ for individuals receiving other forms of TT.

\section{Relationship between parasite-related and patient-related outcomes}

Appended Figure 7 and Figure 8 show our meta-regression analysis of odds of having positive serology after TT and patient-related efficacy outcomes. We did not identify a relationship between our dependent variables (effect of TT on progression of CCC or mortality) and the effect of TT on serology in the studies providing such information (regression slope non-significantly different from 1 in either case). 
Figure 7. Meta-regression analysis. Relationship between effect of TT on progression of CCC and serology.

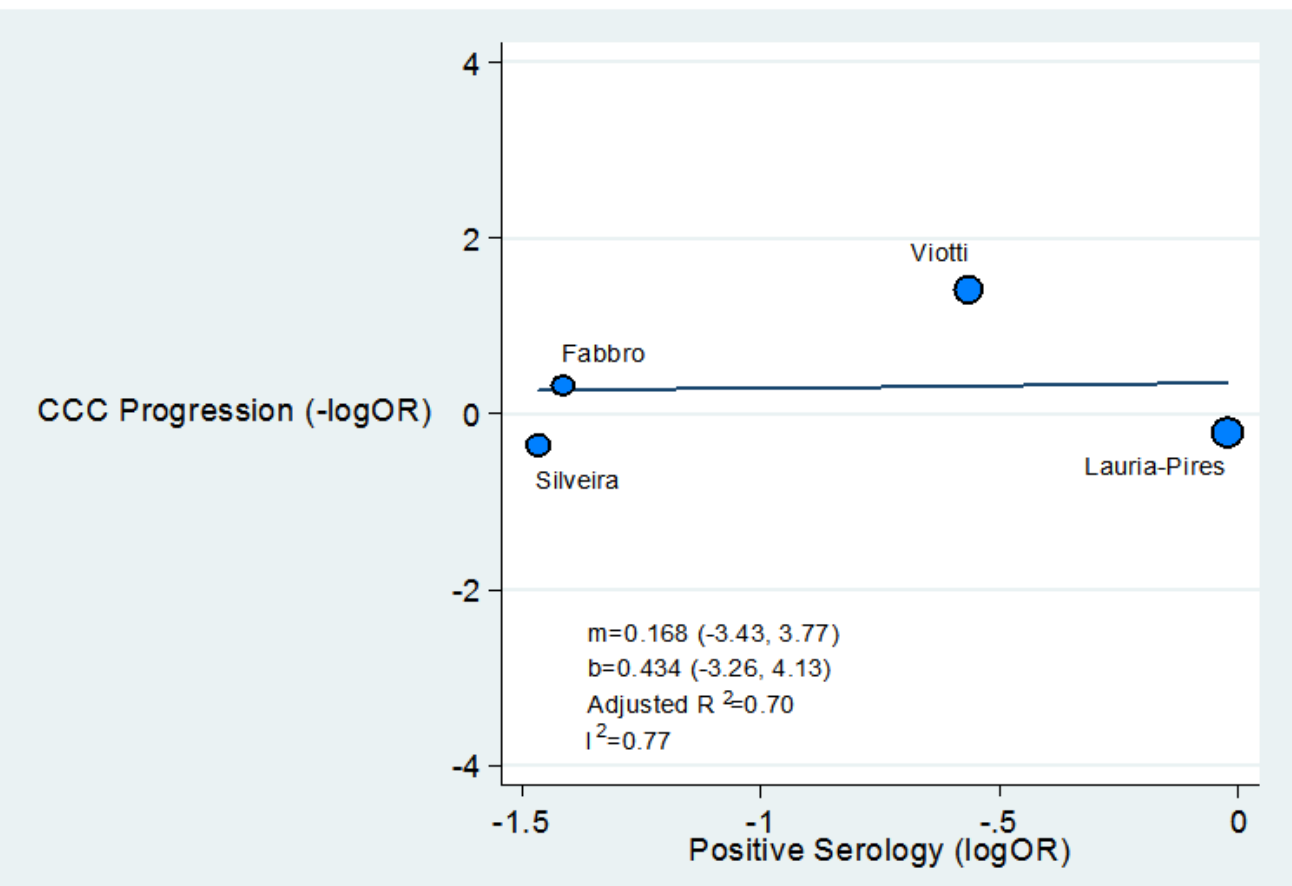


Figure 8. Meta-regression analysis. Relationship between effect of TT on mortality and serology.

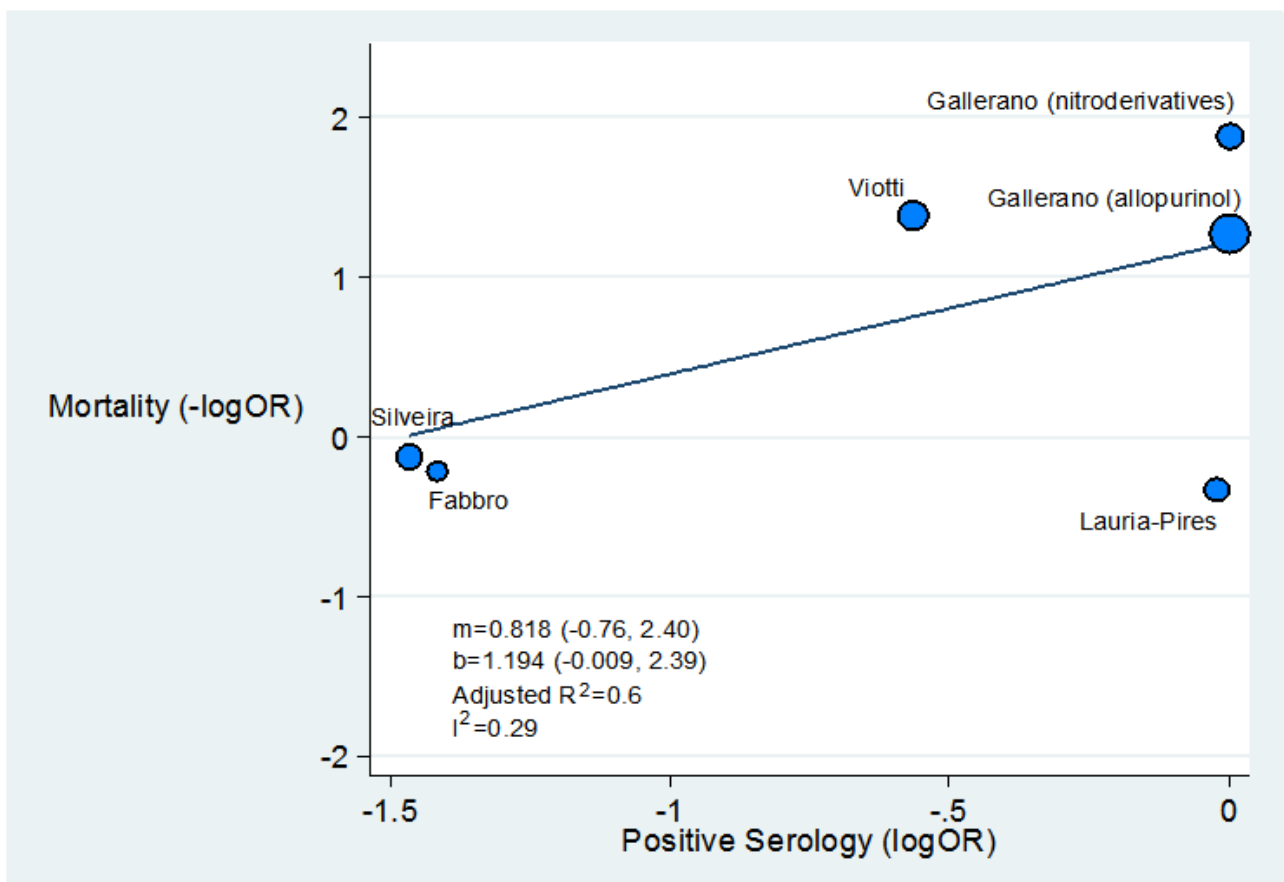

\section{DISCUSSION}

This review included considerably more information than our previous version, allowing validation of NFTMX and BZD as standard forms of TT. However, the substantial growth of the data available is largely from observational studies. Thus, the studies are at substantial risk of bias and convincing results (i.e. those needed to support the notion that TT is generally beneficial for $T$. cruzi-infected individuals) would require methodologically robust studies yielding a large and precise effect size and consistent results. This is not the case for the data summarised in this review, as data on clinical efficacy of TT remains imprecise and highly inconsistent.

\section{Summary of main results}

This updated systematic review provides three major findings: first, a substantial growth in the information produced on this topic since 2000. Second, more results favouring the efficacy of TT, although hampered by methodological flaws, imprecision and inconsistency. Third, a more reliable estimate of the side effects of conventional drugs.

The first version of this review presented data from five RCTs including 756 participants reporting predominantly parasiterelated outcomes. Now, some of those RCTs (i.e. Andrade 2004) have reported extended follow-up periods and provide data regarding a new parasite-related outcome, T. cruzi circulating materials detected by PCR techniques. This review also adds safety data from a relatively large, blinded RCT of TT with BZD in adults (the TRAENA trial, still ongoing, with results on efficacy pending). Further, inclusion of non-RCTs allowed extraction of additional patient-related outcome data from over 3000 individuals. This growth in the amount of information reflects the renewed interest for TT and for resolving the uncertainty around its efficacy.

This data-enhanced review confirms the validity (i.e. proof of concept) of TT as a treatment reducing parasite-related outcomes (including now a positive PCR after treatment). It also suggests that TT reduces both mortality and progress of the associated CCC. However, this potential reduction in outcomes such as ECG abnormalities, progression of CCC and mortality is associated with a number of limitations.

First, our patient-related outcome data on efficacy originate from studies other than RCTs. In seeking this type of information, we accepted the inclusion of studies in which allocation to TT was both non-randomised and open-label. We tried to reduce bias by extracting outcome data that were less prone to influence from assessors (i.e. 'hard' outcomes). Examples included extracting data on severe, rather than mild side effects, and defining progress of CCC as a composite change, rather than an isolated finding, or 
after at least four years of follow-up. Since the only patient-related efficacy outcome data generated from RCTs were seven cases of new ECG abnormalities in two studies, definitive interpretation of clinical efficacy of TT was not possible on the basis of the currently available data.

Second, in addition to our concerns on validity, there is imprecision and statistical heterogeneity of the combined effect size estimates. For example, mortality data for nitroderivatives (the best-known drugs as valid TT in terms of reducing parasiterelated outcomes) still appears to include a risk excess of $56 \%$ among individuals receiving active treatment. Furthermore, heterogeneity for mortality or progression of CCC for adults treated with nitroderivatives remains substantial ( ${ }^{2}$ statistics of $49 \%$ for mortality and $66 \%$ for progression).

Third, as shown by meta-regression analysis, efficacy data on patient-related outcomes have no relationship to results on serology. In addition, the efficacy of ALLOP was greater than that of nitroderivatives in terms of progress of CCC and mortality, but was smaller in terms of parasite-related outcomes. In summary, no patient-related efficacy outcome data summarised in this review replicate findings from at least one RCT in terms of both statistical significance and homogeneity.

An additional aspect of our findings derived from having access, for the first time, to data from the TRAENA trial (the first report of an RCT testing BZD in more than 600 adults). This study identified reliably the mild side effects and, along with other studies, provided data on severe side effects. While rash was the mild side effect more strongly associated with BZD (20\% of treated individuals developed moderate rash, a seven-fold greater incidence than controls), participants had several severe side effects.

Treatment with BZD in TRAENA was associated with fever, lymphadenopathy, arthritis and polyneuritis (around $2.5 \%$ versus no participants in the control groups). Combined data showed that TT with both BZD and NFTMX was also associated with hepatitis, at least in the short term. This finding had approximately the same frequency of the other side effects (17 of 578 , or $2.9 \%$ of individuals exposed to TT). TRAENA investigators stopped TT with BZD in $16 \%$ of their participants based on pre-established medical criteria. Overall, $25 \%$ of the BZD-allocated participants interrupted their treatment, as compared with $2 \%$ in the placebo group. In fact, adherence to TT, a treatment lasting usually eight weeks, was overall $80 \%$. Clinicians recommending TT should expect that one in four to five patients abandon their treatment and at least one severe side effect occurring in every 40 treated patients.

\section{Agreements and disagreements with other studies or reviews}

As compared with other reviews in the field, this work has some differences and coincidences. Among different reviews, two publications have appeared as systematic reviews in the field since 2007. The first work focused on the effect of BZD (Perez-Molina 2009), whereas the second review (Bern 2007) aimed at guiding the medical community of the USA to deal with T. cruzi-infected individuals (as a response to the new epidemiological challenges discussed in the Background section of this review).

The review by Perez-Molina also included both RCTs (three studies) and non-RCTs (six studies) testing BZD. These authors included two non-RCTs excluded from this review (Streiger 2004; De Castro 2006), because authors did not record any patient-related outcome or had a follow-up period below four years, or both. In contrast, our review includes two studies testing BZD that these authors did not include (one from Venezuela and one from Brazil), providing data on mortality.

The accompanying meta-analyses on that review showed different results compared with our review for a number of reasons. First, those authors recorded and combined data on parasiterelated outcomes (i.e. xenodiagnoses and serology status) that we analysed separately. Second, for consistency across outcomes, we treated any "positive effect" as a risk reduction (i.e. reduction of the risk of remaining seropositive), whereas these authors reported outcomes in the inverse way (i.e. BZD increased the rate of negative seroconversion). More importantly, our review treated patient-related outcomes as reported by authors, whereas we recorded outcome data based on our standard definition of "clinical progression". Despite reaching a similar conclusion, numerical results of the review by Pérez-Molina and colleagues would have been different, had they included the two studies that we did include (both with results not favouring BZD).

The review by Bern and colleagues aimed at guiding practice in the USA has a broader scope, covering aspects such as diagnosis, classification and treatment, focusing on nitroderivatives, the drugs available through the CDC. The authors did not present a quantitative synthesis of their data. They stated "benznidazole and nifurtimox are the only drugs with proven efficacy against Chagas disease", citing a book chapter and an expert, narrative review as supporting references. This review offered guidance with levels of evidence for different clinical situations.

Our work adds to this literature in a number of ways: extracting data from all relevant studies, both RCTs and non-RCTs; comparing cohorts after at least four years of follow-up; and recording data on clinical progress using a uniform, explicit definition. We treated similarly all drugs tested as hypothetical TT. We presented a quantitative synthesis of these data, dividing the information by type of study design. Finally, we reported all data extracted from RCTs, and only those from the non-RTCs with lower risk of ascertainment biases.

\section{AUTHORS' CONCLUSIONS}

\section{Implications for practice}

The data summarised in this review should make patients, doctors and public health authorities confident that nitroderivatives are a proven form of trypanocidal therapy (TT). For individuals treated with nifurtimox (NFTMX) or benznidazole (BZD), data originated from randomised controlled trials (RCTs) showed substantial reductions in at least two response variables (specialised serology, xenodiagnosis or polymerase chain reaction (PCR)), that were replicated in at least two studies. In contrast, data for individuals treated with the several other drugs tested in the included studies did not meet such criteria.

In contrast, clear inferences on clinical efficacy of TT (depending upon reductions on patient-related outcomes) remain elusive. Clinical care of individuals with chronic Trypanosoma cruzi infection but free of chronic chagasic cardiomyopathy (CCC) is a complex scenario, where lack of definitive evidence for the efficacy of TT compounds to other uncertainties. The imprecision and 
inconsistency of the efficacy data speaks of a treatment that is probably efficacious, but to an as yet unknown extent, include risk of moderate or severe side effects in exposed individuals. When advising on TT for this population, clinicians should also consider that one in five of their patients will not complete this treatment, and one of every 10 of these patients will discontinue because of severe side effects. Finally, as few of the studies were deemed to be of low risk of bias, all results should be currently viewed with caution. Given the above reasons, TT with NFTMX or BZD should be offered to patients after individualised discussion of the persisting uncertainties and a medical appraisal of the risk-benefit ratio.

\section{Implications for research}

Data summarised in this review call for additional research in a number of directions. First, newer, safer forms of TT need formal testing. Clinical investigators can use BZD or NFTMX as comparators for newly proposed drugs with trypanocidal activity. Second, the clinical and statistical heterogeneity across studies testing TT needs further exploration. Assuming that efficacies of different drugs were the same, such variability should come from differences in patients, parasites or both. For example, results from studies included in this review testing BZD showed clearly different results on mortality in Argentina in comparison to Venezuela. A great variability in seroconversion was also seen in a series of more than 2500 BZD- treated children in Honduras, Guatemala and Bolivia (Escriba 2009). The third and more important need is to resolve the clinical efficacy question of TT. It is fortunate that two relatively large trials comparing the outcome of individuals treated with BZD or placebo are now ongoing. One is TRAENA, a study of 600 participants in Argentina, and the other is the BENEFIT study, an international trial designed to recruit 3000 participants (Prado 2008; Marin-Neto 2009). Enormous progress in knowledge about clinical efficacy of TT is expected from these studies, given the differences in the baseline risk and the geographical diversity of their participants.

In conclusion, the well-documented efficacy of TT on parasiterelated outcomes still requires confirmation in terms of patientrelated outcomes. More geographically diverse RCTs, testing newer forms of TT are needed in order to 1 . generate more precise efficacy estimates, 2. explore the heterogeneity of results and 3. allow a better efficacy/tolerance balance of conventional TT options.

\section{ACKNOWLEDGEMENTS}

We thank Drs. A. Gianella, S. Sosa-Estani, C. Silveira and D. Fabbro for providing additional information (on serology titres with antitrypsin enzyme-linked immunosorbent assay (AT ELISA) or conventional serology, or progression to chronic chagasic cardiomyopathy) from their studies. 


\section{R E F E R E N C E S}

\section{References to studies included in this review}

\section{Andrade 1996 \{published data only\}}

de Andrade ALS, De Oliveira RM, Almeida e Silva S, Luquetti A, Travassos LR, Almeida IC, et al. Randomised trial of efficacy of benznidazole in treatment of early Trypanosoma cruzi infection. Lancet 1996;348:1407-13.

\section{Andrade 2004 \{published data only\}}

Andrade AL, Martelli C, Oliveira R, Silva S, Aires A, Soussumi L, et al. Short report: benznidazole efficacy among Trypanosoma cruzi-infected adolescents after a six-year follow-up. American Journal of Tropical Medicine and Hygiene 2004;71(5):594-7.

\section{Apt 1998* \{published data only\}}

Apt W, Aguilera X, Arribada A, Pérez C, Miranda C, Sánchez G, et al. Treatment of chronic Chagas' disease with itraconazole and allopurinol. American Journal of Tropical Medicine and Hygiene 1998;59:133-8.

\section{Britto 2001* \{published data only\}}

Britto C, Silveira C, Cardoso MA, Marques P, Luquetti A, Macêdo V, et al. Parasite persistence in treated chagasic patients revealed by xenodiagnosis and polymerase chain reaction. Memorias do Instituto Oswaldo Cruz 2001;96:1-4.

\section{Catalioti 2001* \{published data only\}}

Catalioti F, Acquatella H. Mortality comparison of 5 years follow up in subjects with chronic Chagas disease with and without benznidazol treatment [Comparación de mortalidad durante seguimiento por 5 años en sujetos con enfermedad de Chagas crónica con y sin tratamiento de benznidazol]. Revista de Biología Tropical 1998;27(Suppl):29-31.

\section{Coura 1997 \{published data only\}}

Coura Rodrigues J, De Abreu LL, Faraco Wilcox HP, Petana W. Comparative controlled study using benznidazole, nifutimox and placebo in chronic Chagas' disease in field areas with interrupted transmission. I. Preliminary Evaluation [Estudo comparativo controlado com emprego de Benznidazole, nifurtimox e placebo, na forma cronica da doenca de Chagas, em uma area de campo com transmissao interrompida. I. Avialação Preliminar]. Revista da Sociedade Brasileira de Medicina Tropical 1997;30:139-44.

\section{Fabbro 2000** \{published data only\}}

Fabbro de Suasnábar D, Arias E, Streiger M, Piacenza M, Ingaramo M, Del Barco M, et al. Evolutive behavior towards cardiomyopathy of treated (nifurtimox or benznidazole) and untreated chronic chagasic patients. Revista de Instituto de Medicina Tropical de Sao Paulo 2000;42(2):99-109.

\section{Gallerano $2000^{\star \star}\{$ published data only\}}

Gallerano R, Sosa R. Intervention study on the natural evolution of Chagas disease: evaluation of specific antiparasitic treatment [Estudio de intervencion en la evolucion natural de la enfermedad de Chagas: evaluacion del tratamiento antiparasitario especifico]. Revista de la Facultad de Ciencias Médicas (Córdoba, Argentina) 2000;57(2):135-62.
Galvão (Andrade substudy) \{published data only\} Galvão L, Chiari E, Macedo A, Luquetti A, Silva S, Andrade AL. PCR assay for monitoring Trypanosoma cruzi parasitemia in childhood after specific chemotherapy. Journal of Clinical Microbiology 2003;41(11):5066-70.

\section{Gianella 1994 \{published data only\}}

Gianella A, Holzman A, Lihoshi N, et al. Efficacy of allopurinol in chronic Chagas disease. Results of a randomized controlled trial in Santa Cruz, Bolivia [Eficacia del alopurinol en la enfermedad de Chagas crónica. Resultados del estudio realizado en Santa Cruz, Bolivia]. Boletín científico del CENETROP 1997;16:25-9.

\section{Lauria-Pires $2000^{\star \star}\{$ published data only\}}

Lauria-Pires L, Braga M, Vexenat A, Nitz N, Simões-Barbosa A, Tinoco D, et al. Progressive chronic chagas heart disease ten years after treatment with anti-Trypanosoma cruzi nitroderivatives. American Journal of Tropical Medicine and Hygiene 2000;63(3,4):111-8.

\section{Prado 2008 \{unpublished data only\}}

Prado N, Hernández Y, De Rissio AM, Esteve M, Riarte A. Security in a randomized control trial (RCT) - TRAENA Study - in adult patients with Chagas disease [La seguridad en un ensayo clínico aleatorizado (ECA) - Estudio TRAENA - en pacientes adultos con Enfermedad de Chagas]. Instituto Nacional de Parasitología Dr M Fatala Chaben, ANLIS GCG Malbrán, Ministerio de Salud 2008.

\section{Rassi 2007 \{published data only\}}

Rassi A, Luquetti AO, Rassi A Jr, Rassi GG, Rassi SG, Da Silva IG, et al. Short report: specific treatment for Trypanosoma cruzi: lack of efficacy of allopurinol in the human chronic phase of Chagas disease. American Journal of Tropical Medicine and Hygiene 2007;76(1):58-61.

\section{Silveira 2000* \{published and unpublished data\}}

Silveira CAN. Avaliação a longo prazo do tratamento específico da doença de chagas [PhD thesis]. Distrito Federal, Brazil: Faculdade de Medicina, Universidade de Brasília, 2000:123pp.

\section{Sosa-Estani 1998 \{published data only\}}

Sosa-Estani S, Segura EL, Ruiz AM, Velazquez E, Porcel BM, Yampotis C. Efficacy of chemotherapy with benznidazole in children in the intermediate phase of Chagas' disease. American Journal of Tropical Medicine and Hygiene 1998;59:526-9.

\section{Viotti 2006* \{published data only\}}

Viotti R, Vigliano C, Bertocchi G, Petti M, Alvarez MG, Postan M, et al. Long-term cardiac outcomes of treating chronic Chagas disease with benznidazole versus no treatment: a nonrandomized trial. Annals of Internal Medicine 2006;144(10):724-37. 


\section{References to studies excluded from this review}

Abitbol 1981 \{published data only\}

Abitbol H. Treatment of Chagas disease [Tratamiento de la enfermedad de Chagas]. Anales de la Real Academia Nacional de Medicine (Madr) 1981;98:755-8.

Aguilera 1987 \{published data only\} Aguilera X, Apt W, Arribada A. [Evaluación del allopurinolen la enfermedad de Chagas crónica humana en Chile]. Parasitol Dia 1987;11:132-4.

\section{Amato 1980 \{published data only\}}

Amato NV. Specific treatment of Chagas' disease [Tratamento específico da doença de Chagas]. Revista do Hospital das Clínicas 1980;35:27-34.

\section{Amato 1998 \{published data only\}}

Amato NV. Therapeutics of the chronic form of Chagas' disease. Specific treatment of Trypanosoma cruzi infection [Terapêutica da forma crônica da doençade Chagas]. Arquivos Brasileiros de Cardiologia 1998;70:63-4.

\section{Andrade 1973 \{published data only\}}

Andrade SG, Macedo V. Combined treatment of Chagas' disease with Bayer 2502 and corticoid (experimental and clinical study) [Tratamento combinado dadoença de Chagas com Bayer 2502 e corticóide (Estudo experimental e clínico)]. Revista do Instituto de Medicina Tropical de Sao Paulo 1973;15:421-30.

Andrade 1992 \{published data only\}

Andrade SG, Rassi A, Magalhaes JB, Ferriolli FF, Luquetti AO. Specific chemotherapy of Chagas disease: a comparison between the response in patients and experimental animals inoculated with the same strains. Transactions of the Royal Society of Tropical Medicine and Hygiene 1992;86:624-6.

Apt 1985 \{published data only\}

Apt W. Treatment of Chagas' disease [Tratamiento de la enfermedad de Chagas]. Revista Medica de Chile 1985;113:162-6.

\section{Apt 1994 \{published data only\}}

Apt W, Aguilera X, Arribada A, Perez C, Miranda C, Zulantay I, et al. Treatment of chronic human Chagas disease with itraconazole and allopurinol. Preliminary report [Tratamiento de la enfermedad de Chagashumana con Itraconazol y alopurinol. Informe preliminar]. Revista Medica de Chile 1994;122:420-7.

\section{Apt 2003 \{published data only\}}

Apt W, Arribada A, Zulantay I, Sanchez G, Vargas SL, Rodriguez J. Itraconazole or allopurinol in the treatment of chronic American trypanosomiasis: the regression and prevention of electrocardiographic abnormalities during 9 years of follow-up. Annals of Tropical Medicine and Parasitology 2003;97(1):23-9.

Apt 2005 \{published data only\}

Apt W, Arribada A, Zulantay I, Solari A, Sanchez G, Mundaca K, et al. Itraconazole or allopurinol in the treatment of chronic American trypanosomiasis: the results of clinical and parasitological examinations 11 years post-treatment. Annals of Tropical Medicine and Parasitology 2005;99(8):733-41.

Bestetti 1997 \{published data only\}

Bestetti RB. Should benznidazole be used in chronic Chagas' disease?. Lancet 1997;349:653.

Bocca Tourres 1969 \{published data only\}

Bocca Tourres CL. Acute period of Chagas' disease and its treatment with Bay 2502 [La enfermedad de Chagas en periodo agudo y su tratamiento con el Bay 2502]. Boletin Chilenocde Parasitologia 1969;24:24-7.

Braga 2000 \{published data only\}

Braga S, Lauria-Pires L, Argañaraz E, Nascimento R, Teixeira A. Persistent infections in chronic Chagas' disease patients treated with anti-Trypanosoma cruzi nitroderivatives. Revista do Instituto de Medicina Tropical de Sao Paulo 2000;42(3):157-61.

Braga 2006 \{published data only\} Braga JCV, Reis F, Aras R, Costa ND, Bastos C, Silva R, et al. Clinical and therapeutic aspects of heart failure due to Chagas disease. Arquivos Brasileiros de Cardiologia 2006;86(4):296-301.

Brener 1975 \{published data only\}

Brener Z. Chemotherapy of Trypanosoma cruzi infections. Advances in Pharmacological Chemotherapy 1975;13:1-81.

Cançado 2002 \{published data only\}

Cançado JR. Long term evaluation of etiological treatment of Chagas disease with benznidazole. Revista do Instituto de Medicina Tropical de Sao Paulo 2002;44(1):29-37.

Carpintero 1993 \{published data only\}

Carpintero DJ. [Quimioterapia antiparasitaria en la tripanosomiasis americana (Enfermedad de Chagas). Relatode 15 años de experiencia]. CM Publicación Médica 1993;6:117-31.

Chippaux 2010 \{published data only\}

Chippaux JP, Salas Clavijo A, Santalla J, Postigo J, Schneider D, Brutus L. Antibody drop in newborns congenitally infected by Trypanosoma cruzi treated with benznidazole. Tropical Medicine and International Health 2010;15(1):87-93.

Coura 1996 \{published data only\}

Coura JR. Current prospects of specific treatment of Chagas' disease [Perspectivas actuales en el tratamiento específico de la enfermedad de Chagas]. Boletin Chileno de Parasitologia 1996;51:69-75.

Cutrullis 2007 \{published data only\}

Cutrullis R, Ballering G, Altcheh J, Moscatelli G, Corral R, Petray P, et al. Anti-M2 muscarinic receptor autoantibodies in Trypanosoma cruzi-infected pediatric patients treated with benznidazole. Revista de Patologia Tropical 2007;36(2):141-8.

De Araujo Malta 1993 \{published data only\}

De Araujo Malta J. [Terapêutica etiológica da doença de Chagas. Consensos e divergências]. Arquivos Brasileiros de Cardiologia 1993;61:201-2. 
De Castro 2006 \{published data only\}

De Castro AM, Luquetti AO, Rassi A, Chiari E, Galvão LM. Detection of parasitemia profiles by blood culture after treatment of human chronic Trypanosoma cruzi infection. Parasitology Research 2006;99:379-83.

\section{De Lana 2009 \{published data only\}}

De Lana M, Lopes L, Martins H, Bahia M, Machado-de-Assis G, Wendling $A$, et al. Clinical and laboratory status of patients with chronic Chagas disease living in a vector-controlled area in Minas Gerais, Brazil, before and nine years after aetiological treatment. Memorias do Instituto Oswaldo Cruz 2009;104(8):1139-47.

\section{De Oliveira 1967 \{published data only\}}

De Oliveira H. [Tratamento da doença de Chagas (Fase aguda) com Bayer 2502]. Revista do Instituto de Medicina Tropical Sao Paulo 1967;9:343-5.

\section{De Oliveira 1990 \{published data only\}}

De Oliveira H. [Tratamento da forma indeterminada da doença de Chagas com Nifurtimox e Benznidazol]. Revista da Sociedade Brasileira de Medicina Tropical 1990;23:209-11.

Fabbro 2007 \{published data only\}

Fabbro D, Streiger M, Arias E, Bizai M, Barco M, Amicone N. Trypanocide treatment among adults with chronic Chagas disease living in Santa Fe City (Argentina), over a mean followup of 21 years: parasitological, serological and clinical evolution [Tratamiento tripanocida em adultos chagasicos cronicos, residentes na cidade de Santa Fe (Argentina), com sequimento de 21 anos em media: evolucao parasitologica, sorolgica e clinica]. Revista da Sociedade Brasileira de Medicina Tropical 2007;40(1):1-10.

\section{Fernandes 2009 \{published data only\}}

Fernandes C, Teicher F, Balbinot M, Liarte D, Scholl D, Steindel M, et al. Efficacy of benznidazol treatment for asymptomatic chagasic patients from state of Rio Grande do Sul evaluated during a three years follow-up. Memorias do Instituto Oswaldo Cruz 2009;104(1):27-32.

\section{Fernandez 1969 \{published data only\}}

Fernandez JJ, Cedillos RA, Godoy GA. Treatment of acute Chagas' disease with Bay 2502 [Tratamiento de la enfermedad de Chagas crónica con Bay 2502]. Boletin Chileno de Parasitologia 1969;24:51-3.

\section{Fragata Filho 1995 \{published data only\}}

Fragata Filho AA, da Silva MA, Boainain E. Ethiologic treatment of acute and chronic Chagas' disease. Revista Paulista de Medicina 1995;113:867-72.

\section{Fragata-Filho 1995 \{published data only\}}

Fragata-Filho AA, Boainaim E, Dias da Silva MA. Validade do tratamento etiológico na fase crônica da doença de Chagas com benznidazol. Arquivos Brasileiros de Cardiologia 1995;65(Suppl I):71.
Gallerano 1990a \{published data only\}

Gallerano RH, Marr JJ, Sosa RR. Therapeutic efficacy of allopurinol in patients with chronic Chagas' disease. American Journal of Tropical Medicine and Hygiene 1990;43:159-66.

Gallerano 1990b \{published data only\}

Gallerano RH, Sosa RR. [Allopurinol vs testigo en la parasitemia de la enfermedad de Chagas crónica asintomática valorada por xenodiagnósticos seriados]. Boletín Científico del CENETROP 1990;14:38-43.

Gonnert 1972 \{published data only\}

Gonnert R. Nifurtimox: causal treatment of Chagas' disease. Arzneimittelforschung 1972;22:1563.

Gutteridge 1976 \{published data only\}

Gutteridge WE. Chemotherapy of Chagas' disease. Transactions of the Royal Society of Tropical Medicine and Hygiene 1976;70:123-4

Ivanovic 1994 \{published data only\}

Ivanovic D. [Actualizacion sobre el tratamiento de la enfermedad de la enfermedad de Chagas]. Revista Chilena de Infectologia 1994;11:131-8.

\section{Lacunza 2006 \{published data only\}}

Lacunza C, Negrete O, Mora M, Uncos A, Segura M, Castillo N, et al. Use of the polymerase chain reaction (PCR) for early evaluation of etiological treatment in young adults, chronically infected with Trypanosoma cruzi. Revista de Patologia Tropical 2006;35(3):227-32

\section{Levi 1971 \{published data only\}}

Levi GC, Amato NV. Treatment of patients with chronic Chagas' disease by means of the nitrofuran compound Bayer 2502 or Lampit [Observaçoes sôbre o tratamento de pacientes com a forma crônica da doença de Chagas mediante emprêgo do composto nitrofurânico "Bayer 2502" o "lampit"]. Revista do Instituto de Medicina Tropical de Sao Paulo 1971;13:369-72.

Levi 1996 \{published data only\}

Levi GC, Lobo IM, Kallas EG, Amato Neto V. Etiological drug treatment of human infection by Trypanosoma cruzi. Revista do Instituto de Medicina Tropical de Sao Paulo 1996;38:35-8.

López-Antuñaño 1997 \{published data only\}

López-Antuñaño FJ. [Quimioterapia de las infecciones producidas por Trypanosoma cruzi]. Salud Pública de México 1997;39:463-71.

\section{Maldonado 1997 \{published data only\}}

Maldonado M, Vera de Bilbao N, Samudio M, Schinini A, Acosta N, López E, et al. [Tratamiento con benznidazol en niños de seis a doce años infectados con T. cruzi]. EFACIM-EDUNA 1997:154-63.

\section{Marr 1986 \{published data only\}}

Marr JJ, Docampo R. Chemotherapy for Chagas' disease: a perspective of current therapy and considerations for future research. Reviews of Infectious Diseases 1986;8:884-903. 


\section{Martins-Filho 2002 \{published data only\}}

Martins-Filho O, Eloi-Santos S, Carvalho A, Oliveira R, Rassi A, Luquetti $O$, et al. Double-blind study to evaluate flow cytometry analysis of anti-live Trypomastigote antibodies for monitoring treatment efficacy in cases of human Chagas' disease. Clinical and Diagnostic Laboratory Immunology 2002;9(5):1107-13.

\section{Meirovich 1985 \{published data only\}}

Meirovich Cl, Montrull HL, Gallerano RH, Sosa RR. Allopurinol in the treatment of chronic Chagas' disease [Allopurinol en el tratamiento de la enfermedad de Chagas crónica]. Arquivos Brasileiros de Cardiologia 1985;45:217-23.

\section{Mendoza 1992 \{published data only\}}

Mendoza I, Guiniger A, Velazco V, Marques J, Moleiro F, Sgammini H. Opinion of the USCAS Electrophysiology Committee on the treatment of ventricular arrhythmias in Chagas disease [Opinión del Comité de Electrofisiología de USCAS sobre el tratamiento de las arritmias ventricularesen la enfermedad de Chagas]. Rev Urug Cardiol 1992;7:25-8.

\section{Pérez-Molina 2009 \{published data only\}}

Pérez-Molina J, Pérez-Ayala A, Morena S, Fernández-González C, Zamora J, López-Velez R. Use of benznidazole to treat chronic Chagas' disease: a systematic review with a meta-analysis. Journal of Antimicrobial Chemotherapy 2009;64:1139-47.

\section{Prata 1978 \{published data only\}}

Prata A. Possibility of treatment in Chagas' disease [Possibilidade de tratamento na doença de Chagas]. Revista da Associacao Medica Brasileira (1992) 1978;24:140-2.

\section{Rassi 1982 \{published data only\}}

Rassi A. Etiological treatment of Chagas' disease [Tratamento etiológico da doença de Chagas]. Arquivos Brasileiros de Cardiologia 1982;38:277-81.

\section{Romeu Cançado 1976 \{published data only\}}

Romeu Cançado J, Salgado A, Cardoso dos Santos JF, Batista SM, Chiair CC. Clinical trials in Chagas' disease. New Approaches in American Trypanosomiasis Research. 1. Washington, DC: PAHO 1976:266-72.

\section{Rubio 1969 \{published data only\}}

Rubio M, Donoso F. Chagas' disease in children and its treatment with Bay 2502 [Enfermeda de Chagas en niños y tratamiento con Bay 2502]. Boletin Chileno de Parasitologia 1969;24:43-8.

\section{Santana 1969 \{published data only\}}

Santana ET, Magalhaes J Jr, Nagashiro E, Nagashiro A, Sadae G, Delfino SA. [Doença de Chagas crônica. Situaçao actual de seu tratamento]. O Hospital 1969;76:67-75.

\section{Silveira 2000 \{published data only\}}

Silveira C, Castillo E, Castro C. Specific treatment evaluation for Trypanosoma cruzi in children in the evolution of the indeterminate phase [Avaliacão do tratamento específico para o Trypanosoma cruzi em criancas, naevolucão da fase indeterminada]. Revista da Sociedade Brasileira de Medicina Tropical 2000;33(2):191-6.

\section{Sosa-Estani 2004 \{published data only\}}

Sosa-Estani S, Armenti A, Araujo G, Viotti R, Lococo B, Ruiz Vera B, et al. Treatment of Chagas disease with benznidazole and thioctic acid [Tratamiento de la enfermedad de Chagas con benznidazol y acido tioctico]. MEDICINA (Buenos Aires) 2004;64:1-6.

\section{Streiger 2004 \{published data only\}}

Streiger M, Del Barco M, Fabbro D, Arias E, Amicone N. Longitudinal study and specific chemotherapy in children with chronic Chagas' disease, residing in a low endemicity area of Argentina [Estudo longitudinal e quimioterapia específica em criancas, com doenca de Chagas cronica, residentes em area de baixa endemicidade da republica Argentina]. Revista da Sociedade Brasieira de Medicina Tropical 2004;37(5):365-75.

\section{Viotti 1994 \{published data only\}}

Viotti R, Vigliano C, Armenti H, Segura E. Treatment of chronic Chagas' disease with benznidazole: clinical and serologic evolution of patients with long-term follow-up. American Heart Journal 1994;127:151-62.

\section{Wegner 1972a \{published data only\}}

Wegner DH, Rohwedder RW. The effect of nifurtimox in acute Chagas' infection. Arzneimittelforschung 1972;22:1624-35.

\section{Wegner 1972b \{published data only\}}

Wegner DH, Rohwedder RW. Experience with nifurtimox in chronic Chagas' infection. Preliminary report. Arzneimittelforschung 1972;22:1635-41.

\section{Zulantay 2005 \{published data only\}}

Zulantay I, Arribada A, Honores P, Sánchez G, Solari A, Ortiz S, et al. No association between persistence of the parasite and electrocardiographic evolution in treated patients with Chagas disease [La mejoría electrocardiográfica con el tratamiento de la enfermedad de Chagas crónica, es independiente de la persistencia de Trypanosoma cruzi]. Revista Medica de Chile 2005;113:1153-60.

\section{References to ongoing studies}

Marin-Neto 2009 \{published data only\}

Marin-Neto JA, Rassi A Jr, Avezum A Jr, Mattos AC, Rassi A, Morillo CA, et al. The BENEFIT trial: testing the hypothesis that trypanocidal therapy is beneficial for patients with chronic Chagas heart disease. Memoria do Instituto Oswaldo Cruz 2009;104 Suppl 1:319-24.

\section{Additional references}

\section{Andrade 1991}

Andrade SG, Freitas LAR, Peyrol S, Pimentel AR, Sadigursky M. Experimental chemotherapy of Trypanosoma cruzi infection: persistence of parasite antigens and positive serology in parasitologically cured mice. WHO Bulletin OMS 1991;69:191-7.

\section{Apt 1998}

Apt W, Aguilera X, Arribada A, Perez C, Miranda C, Sanchez G, et al. Treatment of chronic Chagas' disease with itraconazole and 
allopurinol. American Journal of Tropical Medicine and Hygiene 1998;59(1):133-8.

\section{Bahia 2012}

Bahia MT, de Andrade IM, Martins TA, do Nascimento ÁF, Diniz $L$ de $F$, Caldas IS, et al. Fexinidazole: a potential new drug candidate for Chagas disease. PLoS Neglected Tropical Diseases 2012;6(11):1-9.

\section{Bern 2007}

Bern C, Montgomery SP, Herwaldt BL, Rassi A Jr, Marin-Neto JA, Dantas RO, et al. Evaluation and treatment of Chagas disease in the United States: a systematic review. JAMA 2007;298:2171-81.

\section{Bern 2009}

Bern C, Montgomery SP. An estimate of the burden of Chagas disease in the United States. Clinical Infectious Diseases 2009;49(5):e52-4.

\section{Chagas 1909}

Chagas CA. [Ajente etiolojico de nova entidade morbida do homem]. Memorias do Instituto Oswaldo Cruz 1909;1(1):11-80.

\section{Coura 2005}

Coura JR. Chagas disease: clinical and therapeutic features. Enfermedades Emergentes 2005;7:18-24.

\section{Coura 2010}

Coura JR, Vinas PA. Chagas disease: a new worldwide challenge. Nature 2010;465:S6-7.

\section{Dias 2009}

Dias JCP. Elimination of Chagas disease transmission: perspectives. Memorias do Instituto Oswaldo Cruz 2009;104:41-5

\section{Escriba 2009}

Escriba JM, Ponce E, Romero Ade D, Vinas PA, Marchiol A, Bassets $\mathrm{G}$, et al. Treatment and seroconversion in a cohort of children suffering from recent chronic Chagas infection in Yoro, Honduras. Memorias do Instituto Oswaldo Cruz 2009;104(7):986-91. [PUBMED: 20027465]

\section{Follmann 1992}

Follmann D, Elliott P, Suh I, Curter J. Variance imputation for overviews of clinical trials with continuous response. Journal of Clinical Epidemiology 1992;45:769-73.

\section{Freitas 2005}

Freitas HF, Chizzola PR, Paes AT, Lima AC, Mansur AJ. Risk stratification in a Brazilian hospital-based cohort of 1220 outpatients with heart failure: role of Chagas' heart disease. International Journal of Cardiology 2005;102(2):239-47.

\section{Gallerano 2001}

Gallerano R, Sr. [Resultados de un estudio a largo plazo con drogas antiparasitarias en infectados chagásicos crónicos]. Revista de la Federación Argentina de Cardiología 2001;30:289-96.

\section{Galvao 2003}

Galvao LM, Chiari E, Macedo AM, Luquetti AO, Silva SA, Andrade AL. PCR assay for monitoring Trypanosoma cruzi parasitemia in childhood after specific chemotherapy. Journal of Clinical Microbiology 2003;41:5066-70.

\section{García 2005}

García S, Ramos CO, Senra JF, Vilas-Boas F, Rodrigues MM, Campos de Carvalho AC, et al. Treatment with benznidazole during the chronic phase of experimental Chagas' disease decreases cardiac alterations. Antimicrobial Agents and Chemotherapy 2005;49(4):1521-8.

\section{Grupo de trabajo científico OMS 2007}

Grupo de trabajo científico OMS. [Reporte sobre la enfermedad de Chagas]. 2007; Vol. 17-20 de abril de 2005 (Actualizado en julio de 2007) - Buenos Aires Argentina.

\section{Guhl 2005}

Guhl F, Restrepo M, Angulo VM, Antunes CM, CampbellLendrum D, Davies CR. Lessons from a national survey of Chagas disease transmission risk in Colombia. Trends in Parasitology 2005;21(6):259-62.

\section{Hagar 1991}

Hagar JM, Rahimtoola SH. Chagas' heart disease in the United States. New England Journal of Medicine 1991;325(11):763-8.

\section{Higgins 2011}

Higgins JPT, Green S (editors). Cochrane Handbook for Systematic Reviews of Intervention Version 5.1.0 [updated March 2011]. The Cochrane Collaboration, 2011. Available from www.cochrane-handbook.org.

\section{Higuchi 2003}

Higuchi ML, Benvenuti LA, Martins RM, Metzger M. Pathophysiology of the heart in Chagas' disease: current status and new developments. Cardiovascular Research 2003;60(1):96-107.

\section{Hotez 2008}

Hotez PJ, Bottazzi ME, Franco-Paredes C, Ault SK, Periago MR. The neglected tropical diseases of Latin America and the Caribbean: a review of disease burden and distribution and a roadmap for control and elimination. PLoS Neglected Tropical Diseases 2008;2(9):e300.

\section{Jones 1993}

Jones EM, Colley DG, Tostes S, Lopes ER, Vnencak-Jones CL, McCurley TL. Amplification of a Trypanosoma cruzi DNA sequence from inflammatory lesions in human chagasic cardiomyopathy. American Journal of Tropical Medicine and Hygiene 1993;48:348-57.

\section{Kuschnir 1985}

Kuschnir E, Sgammini H, Castro R, Evequoz C, Ledesma R, Brunetto J. Evaluation of cardiac function by radioisotopic angiography, in patients with chronic Chagas cardiopathy. Arquivos Brasileiros de Cardiologia 1985;45(4):249-56. 


\section{Laranja 1956}

Laranja FS, Dias E, Nobrega G, Miranda A. Chagas' disease: a clinical, epidemiologic, and pathologic study. Circulation 1956;14(6):1035-60.

\section{Lauria-Pires 2000}

Lauria-Pires L, Braga MS, Vexenat AC, Nitz N, Simoes-Barbosa A, Tinoco DL, et al. Progressive chronic Chagas heart disease ten years after treatment with anti-Trypanosoma cruzi nitroderivatives. American Journal of Tropical Medicine and Hygiene 2000;63(3-4):111-8.

\section{Lefebvre 2011}

Lefebvre C, Manheimer E, Glanville J. Chapter 6: Searching for studies. In: Higgins JPT, Green S (editors). Cochrane Handbook for Systematic Reviews of Interventions Version 5.1.0 [updated March 2011]. The Cochrane Collaboration, 2011. Available from www.cochrane-handbook.org.

\section{López 2009}

López S, Risech E, Riarte A. [A nueve años de un estudio de tratamiento en adultos (TRAENA) con enfermedad de Chagas crónica: adherencia a los controles y expectativas de curación]. 2008.

\section{Marinho 1999}

Marinho CR, Imperio Lima MR, Grisotto MG, Alvarez JM. Influence of acute-phase parasite load on pathology, parasitism, and activation of the immune system at the late chronic phase of Chagas' disease. Infection and Immunity 1999;67(1):308-18.

\section{Moncayo 2003}

Moncayo A. Chagas disease: current epidemiological trends after the interruption of vectorial and transfusional transmission in the Southern Cone countries. Memorios do Instituto Oswaldo Cruz 2003;98(5):577-91.

\section{Perez-Molina 2009}

Perez-Molina JA, Perez-Ayala A, Moreno S, FernandezGonzalez MC, Zamora J, Lopez-Velez R. Use of benznidazole to treat chronic Chagas' disease: a systematic review with a meta-analysis. Journal of Antimicrobial Chemotherapy 2009;64:1139-47.

\section{CHARACTERISTICS OF STUDIES}

Characteristics of included studies [ordered by study ID]

\section{RevMan 2012 [Computer program]}

The Nordic Cochrane Centre, The Cochrane Collaboration. Review Manager (RevMan). Version 5.2. Copenhagen: The Nordic Cochrane Centre, The Cochrane Collaboration, 2012.

\section{Reyes 2005}

Reyes PA, Vallejo M. Trypanocidal drugs for late stage, symptomatic Chagas disease (Trypanosoma cruzi infection). Cochrane Database of Systematic Reviews 2005, Issue 4. [DOI: 10.1002/14651858.CD004102.pub2]

\section{Sosa 1999}

Sosa ES, Segura EL. [Tratamiento de la infeccion por Trypanosoma cruzi en fase indeterminada. Experiencia y normatizacion actual en la Argentina]. Medicina 1999;59 Suppl 2:166-70.

\section{Villar 2001}

Villar JC. Commentary: control of Chagas' disease: let's put people before vectors. International Journal of Epidemiology 2001;30(4):894-5.

\section{WHO 2002}

WHO. Control of Chagas disease. Second Report of the WHO Expert Committee. Geneva: WHO, 2002.

\section{WHO 2009}

WHO secretariat. Chagas disease: control and elimination: provisional agenda item 12.12 for the 62th World Health Assembly A62/17, 2009. apps.who.int/iris/ bitstream/10665/2199/1/A62_17-en.pdf?ua=1 (accessed 8 May 2014).

\section{WHO 2010}

WHO. Control and prevention of Chagas disease in Europe, 2010. www.fac.org.ar/1/comites/chagas/ Chagas_WHO_Technical\%20Report_16_06_10.pdf (accessed 8 May 2014).

\section{References to other published versions of this review Villar 2002}

Villar JC, Villar LA, Marin-Neto JA, Ebrahim S, Yusuf S. Trypanocidal drugs for chronic asymptomatic Trypanosoma cruzi infection. Cochrane Database of Systematic Reviews 2002, Issue 1. [10.1002/14651858.CD003463]

\begin{tabular}{ll}
\hline Andrade 1996 & \\
\hline Methods & RCT \\
\hline Participants & School children \\
\hline Interventions & BZD $(\mathrm{n}=64) 7.5 \mathrm{mg} / \mathrm{kg} /$ day $(8$ weeks $)$ \\
& Placebo $(\mathrm{n}=65)$ \\
\hline \hline
\end{tabular}

Trypanocidal drugs for chronic asymptomatic Trypanosoma cruzi infection (Review) 
Andrade 1996 (Continued)

\begin{tabular}{ll} 
Outcomes & Serological status recorded \\
& Antibody titres reported \\
& Incidence of ECG abnormalities reported \\
\hline Notes & Brazil, 1996
\end{tabular}

\section{Risk of bias}

\begin{tabular}{|c|c|}
\hline Bias & Authors' judgement Support for judgement \\
\hline $\begin{array}{l}\text { Random sequence genera- } \\
\text { tion (selection bias) }\end{array}$ & Low risk \\
\hline $\begin{array}{l}\text { Allocation concealment } \\
\text { (selection bias) }\end{array}$ & Low risk \\
\hline $\begin{array}{l}\text { Blinding of participants } \\
\text { and personnel (perfor- } \\
\text { mance bias) } \\
\text { All outcomes }\end{array}$ & Low risk \\
\hline $\begin{array}{l}\text { Incomplete outcome data } \\
\text { (attrition bias) } \\
\text { All outcomes }\end{array}$ & High risk \\
\hline
\end{tabular}

Andrade 2004

\begin{tabular}{ll}
\hline Methods & RCT \\
\hline Participants & School children \\
\hline Interventions & BZN $(\mathrm{n}=64) 7.5 \mathrm{mg} / \mathrm{kg} /$ day (8 weeks) \\
& Placebo $(\mathrm{n}=65)$ \\
\hline Outcomes & Incidence of ECG abnormalities \\
& Serological status recorded \\
\hline Notes & Brazil 2004 \\
& Same study as Galvao 2003 with different outcomes
\end{tabular}

\section{Risk of bias}

Bias Authors' judgement Support for judgement

Random sequence genera- Low risk tion (selection bias)

Allocation concealment Low risk
(selection bias)


Andrade 2004 (Continued)

Blinding of participants Low risk and personnel (performance bias)

All outcomes

\section{Blinding of outcome as- Low risk}

sessment (detection bias)

All outcomes

Incomplete outcome data High risk

(attrition bias)

All outcomes

\section{Apt 1998*}

\begin{tabular}{ll}
\hline Methods & Non-randomised study \\
\hline Participants & Adults \\
\hline Interventions & ALLOP $(\mathrm{n}=104) 8.5 \mathrm{mg} / \mathrm{kg} /$ day $(8$ weeks) \\
& ITRA $(\mathrm{n}=135) 6 \mathrm{mg} / \mathrm{kg} /$ day $(16$ weeks) \\
& Placebo $(\mathrm{n}=165)$ \\
\hline Outcomes & Xenodiagnosis recorded \\
& Side effects \\
\hline Notes & Chile 1998 \\
\hline
\end{tabular}

\section{Risk of bias}

\begin{tabular}{lll}
\hline Bias & Authors' judgement & Support for judgement \\
\hline $\begin{array}{l}\text { Random sequence genera- } \\
\text { tion (selection bias) }\end{array}$ & Unclear risk & Unclear \\
\hline $\begin{array}{l}\text { Allocation concealment } \\
\text { (selection bias) }\end{array}$ & Unclear risk & Unclear \\
\hline
\end{tabular}

\section{Blinding of participants} Low risk and personnel (perfor-

mance bias)

All outcomes

\section{Blinding of outcome as- Low risk}

sessment (detection bias)

All outcomes

Incomplete outcome data Low risk

(attrition bias)

All outcomes 
Britto 2001*

\begin{tabular}{ll}
\hline Methods & Non-randomised study \\
\hline Participants & Adults \\
\hline Interventions & BZD $5-6 \mathrm{mg} / \mathrm{kg} /$ day $(4-8$ weeks $)$ \\
& NFTMX 7-8 $\mathrm{mg} / \mathrm{kg} /$ day $(8-12$ weeks $)$ \\
& Untreated $(\mathrm{n}=15)$ \\
& BZD or NFTMX $(\mathrm{n}=48)$ \\
\hline Outcomes & PCR \\
Notes & Brazil 2001
\end{tabular}

\section{Risk of bias}

\section{Bias \\ Authors' judgement Support for judgement}

Random sequence genera- High risk

tion (selection bias)

Allocation concealment High risk
(selection bias)

(selection bias)

Blinding of participants

High risk

and personnel (perfor-

mance bias)

All outcomes

\begin{tabular}{|c|c|}
\hline $\begin{array}{l}\text { Blinding of outcome as- } \\
\text { sessment (detection bias) } \\
\text { All outcomes }\end{array}$ & Unclear risk \\
\hline
\end{tabular}

Incomplete outcome data Unclear risk Unclear

(attrition bias)

All outcomes

\section{Catalioti 2001*}

\begin{tabular}{ll}
\hline Methods & Non-randomised study \\
\hline Participants & Adults \\
\hline Interventions & BZD $(n=74)$ \\
& Untreated $(n=465)$ \\
\hline Outcomes & Mortality \\
\hline Notes & Venezuela 2001 \\
\hline
\end{tabular}

\section{Risk of bias}


Catalioti 2001* (Continued)

Bias

\section{Authors' judgement Support for judgement}

Random sequence genera- High risk tion (selection bias)

\section{Allocation concealment High risk}

(selection bias)

Blinding of participants

and personnel (perfor-

High risk

mance bias)

All outcomes

\begin{tabular}{lll}
\hline $\begin{array}{l}\text { Blinding of outcome as- } \\
\text { sessment (detection bias) }\end{array}$ & Unclear risk & \\
All outcomes & & \\
\hline $\begin{array}{l}\text { Incomplete outcome data } \\
\text { (attrition bias) }\end{array}$ & Unclear risk & Unclear \\
All outcomes & &
\end{tabular}

\section{Coura 1997}

\begin{tabular}{ll}
\hline Methods & Non-randomised study \\
\hline Participants & Adults \\
\hline Interventions & BZD $(\mathrm{n}=26) 5 \mathrm{mg} / \mathrm{kg} /$ day $(4$ weeks) \\
& NFTMX $(\mathrm{n}=27) 5 \mathrm{mg} / \mathrm{kg} /$ day (4 weeks) \\
& Placebo $(\mathrm{n}=24)$ \\
\hline Outcomes & Serological status recorded \\
& Xenodiagnosis recorded \\
\hline Notes & Brazil 1997 \\
\hline
\end{tabular}

\section{Risk of bias}

\section{Bias Authors' judgement Support for judgement}

Random sequence genera- Low risk tion (selection bias)

\begin{tabular}{ll}
\hline $\begin{array}{l}\text { Allocation concealment } \\
\text { (selection bias) }\end{array}$ & Low risk \\
\hline $\begin{array}{l}\text { Blinding of participants } \\
\text { and personnel (perfor- } \\
\text { mance bias) } \\
\text { All outcomes risk }\end{array}$ \\
\hline $\begin{array}{l}\text { Blinding of outcome as- } \\
\text { sessment (detection bias) }\end{array}$
\end{tabular}


Coura 1997 (Continued)

All outcomes

\section{Incomplete outcome data High risk}

(attrition bias)

All outcomes

Fabbro 2000**

\begin{tabular}{ll}
\hline Methods & Observational study \\
\hline Participants & Adults \\
\hline Interventions & BZD $(\mathrm{n}=36) 5 \mathrm{mg} / \mathrm{kg} /$ day $(4$ weeks $)$ \\
& NFTMX $(\mathrm{n}=34) 5 \mathrm{mg} / \mathrm{kg} /$ day $(8$ weeks) \\
& Untreated $(\mathrm{n}=130)$ \\
\hline Outcomes & Serology status recorded \\
& Progression of cardiomyopathy \\
& Mortality \\
\hline Notes & Argentina 2000
\end{tabular}

\section{Risk of bias}

\begin{tabular}{lll}
\hline Bias & Authors' judgement & Support for judgement \\
\hline $\begin{array}{l}\text { Random sequence genera- } \\
\text { tion (selection bias) }\end{array}$ & Unclear risk & Unclear \\
\hline $\begin{array}{l}\text { Allocation concealment } \\
\text { (selection bias) }\end{array}$ & Unclear risk & Unclear \\
\hline $\begin{array}{l}\text { Blinding of participants } \\
\text { and personnel (perfor- } \\
\text { mance bias) }\end{array}$ & High risk & \\
All outcomes & \\
\hline $\begin{array}{l}\text { Blinding of outcome as- } \\
\text { sessment (detection bias) } \\
\text { All outcomes }\end{array}$ & Unclear risk & \\
\hline $\begin{array}{l}\text { Incomplete outcome data } \\
\text { (attrition bias) }\end{array}$ & Unclear risk & Unclear \\
All outcomes & & \\
\hline
\end{tabular}

\section{Gallerano 2000**}

\begin{tabular}{ll}
\hline Methods & Observational study \\
\hline Participants & Adults \\
\hline
\end{tabular}


Gallerano 2000** (Continued)

\begin{tabular}{ll} 
Interventions & BZD $(\mathrm{n}=130) 4-8 \mathrm{mg} / \mathrm{kg} /$ day $(6-8$ weeks) \\
& $\operatorname{NFTMX~}(\mathrm{n}=96) 10 \mathrm{mg} / \mathrm{kg} /$ day $(6-8$ weeks) \\
& $\operatorname{ALLOP}(\mathrm{n}=309) 300,600$ or $900 \mathrm{mg} / \mathrm{kg} /$ day (8 weeks) \\
& Untreated $(\mathrm{n}=668)$ \\
\hline Outcomes & Serology status recorded \\
& Side effects \\
& Progression of cardiomyopathy \\
Mortality
\end{tabular}

\section{Risk of bias}

Bias Authors' judgement Support for judgement

\section{Random sequence genera- High risk tion (selection bias)}

\section{Allocation concealment High risk \\ (selection bias)}

\section{Blinding of participants High risk}

and personnel (perfor-

mance bias)

All outcomes

Blinding of outcome as-
sessment (detection bias) Unclear risk Unclear

\section{Incomplete outcome data Low risk}

(attrition bias)

All outcomes

\section{Galvão (Andrade substudy)}

\begin{tabular}{ll}
\hline Methods & RCT \\
\hline Participants & School children \\
\hline Interventions & BZD $(\mathrm{n}=64) 7.5 \mathrm{mg} / \mathrm{kg} /$ day $(8$ weeks $)$ \\
& Placebo $(\mathrm{n}=65)$ \\
\hline Outcomes & PCR recorded \\
\hline Notes & Substudy of Andrade 2004, different outcomes \\
& Brazil 2003 \\
\hline
\end{tabular}


Galvão (Andrade substudy) (Continued)

Risk of bias

\begin{tabular}{|c|c|}
\hline Bias & Authors' judgement Support for judgement \\
\hline $\begin{array}{l}\text { Random sequence genera- } \\
\text { tion (selection bias) }\end{array}$ & Low risk \\
\hline $\begin{array}{l}\text { Allocation concealment } \\
\text { (selection bias) }\end{array}$ & Low risk \\
\hline $\begin{array}{l}\text { Blinding of participants } \\
\text { and personnel (perfor- } \\
\text { mance bias) } \\
\text { All outcomes }\end{array}$ & Low risk \\
\hline $\begin{array}{l}\text { Blinding of outcome as- } \\
\text { sessment (detection bias) } \\
\text { All outcomes }\end{array}$ & Low risk \\
\hline $\begin{array}{l}\text { Incomplete outcome data } \\
\text { (attrition bias) } \\
\text { All outcomes }\end{array}$ & High risk \\
\hline
\end{tabular}

Gianella 1994

\begin{tabular}{ll}
\hline Methods & RCT \\
\hline Participants & Adults \\
\hline Interventions & ALLOP $(\mathrm{n}=18) 300 \mathrm{mg} 3$ times/day (8 weeks) \\
& Placebo $(\mathrm{n}=22)$ \\
\hline Outcomes & Antibody titres recorded \\
& Xenodiagnosis recorded \\
& Side effects \\
\hline Notes & Bolivia 1994
\end{tabular}

\section{Risk of bias}

\begin{tabular}{lll}
\hline Bias & Authors' judgement & Support for judgement \\
\hline $\begin{array}{l}\text { Random sequence genera- } \\
\text { tion (selection bias) }\end{array}$ & Unclear risk & Unclear \\
\hline $\begin{array}{l}\text { Allocation concealment } \\
\text { (selection bias) }\end{array}$ & Unclear risk & Unclear \\
\hline $\begin{array}{l}\text { Blinding of participants } \\
\text { and personnel (perfor- } \\
\text { mance bias) }\end{array}$ & Low risk \\
All outcomes & \\
\hline
\end{tabular}


Gianella 1994 (Continued)

Blinding of outcome as- Unclear risk Unclear sessment (detection bias)

All outcomes

Incomplete outcome data High risk

(attrition bias)

All outcomes

Lauria-Pires $2000^{* *}$

\begin{tabular}{ll}
\hline Methods & Observational study \\
\hline Participants & Adults \\
\hline Interventions & BZD $(\mathrm{n}=17) 10 \mathrm{mg} / \mathrm{kg} /$ day $(8$ weeks) \\
& NFTMX $(\mathrm{n}=28) 10 \mathrm{mg} / \mathrm{kg} /$ day (8 weeks) \\
& Untreated $(\mathrm{n}=46)$ \\
\hline Outcomes & Serology status recorded \\
& Mortality \\
Notes & Progression of cardiomyopathy
\end{tabular}

\section{Risk of bias}

Bias Authors' judgement Support for judgement

Random sequence genera- High risk

tion (selection bias)

Allocation concealment High risk
(selection bias)

Blinding of participants Unclear risk Unclear
and personnel (perfor-
mance bias)
All outcomes

Blinding of outcome as- Low risk

sessment (detection bias)

All outcomes

Incomplete outcome data High risk

(attrition bias)

All outcomes

\section{Prado 2008}

Methods RCT


Prado 2008 (Continued)

\begin{tabular}{ll} 
Participants & Adults \\
\hline Interventions & BZD $(\mathrm{n}=352)$ \\
& Placebo $(\mathrm{n}=357)$ \\
\hline Outcomes & Side effects \\
\hline Notes & Argentina 2008
\end{tabular}

\section{Risk of bias}

Bias Authors' judgement Support for judgement

Random sequence genera- Low risk tion (selection bias)

\begin{tabular}{lll}
\hline $\begin{array}{l}\text { Allocation concealment Unclear risk } \\
\text { (selection bias) }\end{array}$ & Unclear
\end{tabular}

Blinding of participants Low risk
and personnel (perfor-
mance bias)
All outcomes

\section{Blinding of outcome as- Low risk} sessment (detection bias)

All outcomes

$\begin{array}{ll}\begin{array}{l}\text { Incomplete outcome data } \\ \text { (attrition bias) }\end{array} & \text { Low risk }\end{array}$

All outcomes

\section{Rassi 2007}

\begin{tabular}{ll}
\hline Methods & RCT \\
\hline Participants & Adults \\
\hline Interventions & ALLOP $(\mathrm{n}=23) 4.3 \mathrm{mg} / \mathrm{kg} /$ day $(8$ weeks) \\
& Placebo $(\mathrm{n}=12)$ \\
\hline Outcomes & Xenodiagnosis recorded \\
& Serology status recorded \\
& Side effects \\
\hline Notes & Brazil 2007
\end{tabular}

\section{Risk of bias}


Rassi 2007 (Continued)
Random sequence genera-
Unclear risk
Unclear tion (selection bias)

\begin{tabular}{lll}
\hline $\begin{array}{l}\text { Allocation concealment } \\
\text { (selection bias) }\end{array}$ & Unclear risk
\end{tabular}

Blinding of participants Low risk
and personnel (perfor-
mance bias)
All outcomes

\begin{tabular}{|c|c|}
\hline $\begin{array}{l}\text { Blinding of outcome as- } \\
\text { sessment (detection bias) } \\
\text { All outcomes }\end{array}$ & Unclear risk \\
\hline
\end{tabular}

All outcomes

Incomplete outcome data High risk

(attrition bias)

All outcomes

\section{Silveira 2000*}

\begin{tabular}{ll}
\hline Methods & Non-randomised study \\
\hline Participants & Adults \\
\hline Interventions & BZD $(\mathrm{n}=34)$ \\
& NFTMX $(\mathrm{n}=25)$ \\
& Untreated $(\mathrm{n}=39)$ \\
\hline Outcomes & Serology status recorded \\
& Progression of cardiomyopathy \\
& Mortality \\
\hline
\end{tabular}

\section{Notes}

\section{Risk of bias}

Bias Authors' judgement Support for judgement

Random sequence genera- High risk tion (selection bias)

Allocation concealment High risk
(selection bias)

Blinding of participants High risk
and personnel (perfor-
mance bias)
All outcomes

\begin{tabular}{lll}
\hline $\begin{array}{l}\text { Blinding of outcome as- } \\
\text { sessment (detection bias) }\end{array}$ & Unclear risk & \\
& \\
\hline
\end{tabular}


Silveira 2000* (Continued)

All outcomes

Incomplete outcome data Unclear risk Unclear
(attrition bias)

All outcomes

Sosa-Estani 1998

\begin{tabular}{ll}
\hline Methods & RCT \\
\hline Participants & School children \\
\hline Interventions & BZD $(\mathrm{n}=55) 5 \mathrm{mg} / \mathrm{kg} /$ day $(8$ weeks $)$ \\
& Placebo $(\mathrm{n}=51)$ \\
\hline Outcomes & Serological status recorded \\
& Antibody titres recorded \\
& Xenodiagnosis recorded \\
Incidence of ECG abnormalities \\
Side effects \\
\hline Notes & Argentina 1998
\end{tabular}

\section{Risk of bias}

Bias Authors' judgement Support for judgement

Random sequence genera- Unclear risk Unclear

tion (selection bias)

Allocation concealment Unclear risk Unclear
(selection bias)

Blinding of participants Low risk

and personnel (perfor-

mance bias)

All outcomes

\begin{tabular}{lll}
\hline Blinding of outcome as- & Unclear risk & Unclear \\
sessment (detection bias) &
\end{tabular}

All outcomes

Incomplete outcome data Low risk

(attrition bias)

All outcomes

\section{Viotti 2006*}

Methods Non-randomised study


Viotti 2006* (Continued)

\begin{tabular}{ll} 
Participants & Adults \\
\hline Interventions & BZD $(\mathrm{n}=294) 5 \mathrm{mg} / \mathrm{kg} /$ day $(4$ weeks $)$ \\
& Untreated $(\mathrm{n}=304)$ \\
\hline Outcomes & Serology status \\
& Side effects \\
& Progression of cardiomyopathy \\
& Mortality
\end{tabular}

\section{Notes}

Argentina 2006

Refer to study as subgroup of reported cohort

\section{Risk of bias}

Bias Authors' judgement Support for judgement

Random sequence genera- High risk

tion (selection bias)

Allocation concealment High risk
(selection bias)

Blinding of participants High risk

and personnel (perfor-

mance bias)

All outcomes

\begin{tabular}{ll}
\hline $\begin{array}{l}\text { Blinding of outcome as- } \\
\text { sessment (detection bias) } \\
\text { All outcomes }\end{array}$ & Low risk \\
\hline $\begin{array}{l}\text { Incomplete outcome data } \\
\text { (attrition bias) }\end{array}$ & High risk \\
All outcomes &
\end{tabular}

ALLOP: allopurinol; BZD: benznidazole; ECG: electrocardiogram; ITRA: itraconazole; NFTMX: nifurtimox; PCR: polymerase chain reaction; $\mathrm{RCT}$ : randomised controlled trial.

Characteristics of excluded studies [ordered by study ID]

\begin{tabular}{ll}
\hline Study & Reason for exclusion \\
\hline Abitbol 1981 & Study not reporting original data \\
\hline Aguilera 1987 & Original studies, not RCT \\
\hline Amato 1980 & Study not reporting original data \\
\hline Amato 1998 & Study not reporting original data \\
\hline Andrade 1973 & Original studies, not RCT, not appropriate study population \\
\hline \hline
\end{tabular}




\begin{tabular}{|c|c|}
\hline Study & Reason for exclusion \\
\hline Andrade 1992 & Original studies, not RCT, not appropriate study population \\
\hline Apt 1985 & Study not reporting original data \\
\hline Apt 1994 & Duplicated data \\
\hline Apt 2003 & Observational study of previous RCT, not appropriate outcomes \\
\hline Apt 2005 & Observational study of previous RCT, not appropriate outcomes \\
\hline Bestetti 1997 & Study not reporting original data \\
\hline Bocca Tourres 1969 & Original studies, not RCT, not appropriate study population \\
\hline Braga 2000 & Original studies, not RCT, not appropriate outcomes \\
\hline Braga 2006 & Original studies, not RCT, not appropriate outcomes \\
\hline Brener 1975 & Study not reporting original data \\
\hline Cançado 2002 & Original studies, not RCT, not appropriate outcomes \\
\hline Carpintero 1993 & Original studies, not RCT \\
\hline Chippaux 2010 & Original studies, not RCT, not appropriate outcomes \\
\hline Coura 1996 & Study not reporting original data \\
\hline Cutrullis 2007 & Not appropriate intervention, study not reporting original data \\
\hline De Araujo Malta 1993 & Study not reporting original data \\
\hline De Castro 2006 & Original studies, not RCT, not appropriate outcomes \\
\hline De Lana 2009 & Original studies, not RCT, not appropriate outcomes \\
\hline De Oliveira 1967 & Original studies, not RCT, not appropriate study population \\
\hline De Oliveira 1990 & Original studies, not RCT \\
\hline Fabbro 2007 & Original studies, not RCT, not appropriate outcomes \\
\hline Fernandes 2009 & Original studies, not RCT, not appropriate outcomes \\
\hline Fernandez 1969 & Original studies, not RCT, not appropriate study population \\
\hline Fragata Filho 1995 & Study not reporting original data \\
\hline Fragata-Filho 1995 & Data from an abstract. Complete study not published \\
\hline Gallerano 1990a & Original studies, not RCT \\
\hline Gallerano 1990b & Original studies, not RCT \\
\hline Gonnert 1972 & Original studies, not RCT \\
\hline
\end{tabular}




\begin{tabular}{|c|c|}
\hline Study & Reason for exclusion \\
\hline Gutteridge 1976 & Study not reporting original data \\
\hline Ivanovic 1994 & Study not reporting original data \\
\hline Lacunza 2006 & Original studies, not RCT, not appropriate outcomes \\
\hline Levi 1971 & Original studies, not RCT \\
\hline Levi 1996 & Study not reporting original data \\
\hline López-Antuñaño 1997 & Study not reporting original data \\
\hline Maldonado 1997 & Original studies, not RCT \\
\hline Marr 1986 & Study not reporting original data \\
\hline Martins-Filho 2002 & Original studies, not RCT, not appropriate outcomes \\
\hline Meirovich 1985 & Original studies, not RCT \\
\hline Mendoza 1992 & Study not reporting original data \\
\hline Prata 1978 & Original studies, not RCT \\
\hline Pérez-Molina 2009 & Study not reporting original data \\
\hline Rassi 1982 & Study not reporting original data \\
\hline Romeu Cançado 1976 & Study not reporting original data \\
\hline Rubio 1969 & Original studies, not RCT \\
\hline Santana 1969 & Study not reporting original data \\
\hline Silveira 2000 & Original studies, not RCT, not appropriate outcomes \\
\hline Sosa-Estani 2004 & Original studies, not RCT, not appropriate outcomes and treatment \\
\hline Streiger 2004 & Original studies, not RCT, not appropriate outcomes \\
\hline Viotti 1994 & Original studies, not RCT \\
\hline Wegner 1972a & Original studies, not RCT, not appropriate study population \\
\hline Wegner $1972 b$ & Original studies, not RCT, not appropriate study population \\
\hline Zulantay 2005 & Original studies, not RCT, not appropriate outcomes \\
\hline
\end{tabular}

$\mathrm{RCT}$ : randomised controlled trial.

\section{DATA AND ANALYSES}


Comparison 1. Parasite-related outcomes

\begin{tabular}{|c|c|c|c|c|}
\hline Outcome or subgroup title & $\begin{array}{l}\text { No. of } \\
\text { studies }\end{array}$ & $\begin{array}{l}\text { No. of } \\
\text { partici- } \\
\text { pants }\end{array}$ & Statistical method & Effect size \\
\hline 1 Positive serology & 9 & 3414 & Odds Ratio (M-H, Random, 95\% Cl) & $0.21[0.10,0.44]$ \\
\hline 1.1 RCT data - nitroderivatives & 3 & 524 & Odds Ratio (M-H, Random, 95\% Cl) & $0.12[0.03,0.42]$ \\
\hline $\begin{array}{l}1.2 \text { Non-RCT data - adults - ni- } \\
\text { troderivatives - conventional } \\
\text { serology }\end{array}$ & 5 & 1878 & Odds Ratio (M-H, Random, 95\% Cl) & $0.34[0.16,0.73]$ \\
\hline 1.3 RCT data - allopurinol & 1 & 35 & Odds Ratio (M-H, Random, 95\% Cl) & $2.0[0.11,35.09]$ \\
\hline $\begin{array}{l}1.4 \text { Non-RCT data - adults - al- } \\
\text { lopurinol - conventional serol- } \\
\text { ogy }\end{array}$ & 1 & 977 & Odds Ratio (M-H, Random, 95\% Cl) & $0.07[0.00,1.27]$ \\
\hline $\begin{array}{l}2 \text { Positive PCR: nitroderiva- } \\
\text { tives }\end{array}$ & 2 & 192 & Odds Ratio (M-H, Random, 95\% Cl) & $0.50[0.27,0.92]$ \\
\hline 2.1 RCT data - children & 1 & 129 & Odds Ratio (M-H, Random, 95\% Cl) & $0.51[0.25,1.04]$ \\
\hline 2.2 Non-RCT data - adults & 1 & 63 & Odds Ratio (M-H, Random, 95\% Cl) & $0.48[0.15,1.55]$ \\
\hline $\begin{array}{l}3 \text { Positive xenodiagnosis: all } \\
\text { populations, all tested drugs }\end{array}$ & 6 & 1073 & Odds Ratio (M-H, Random, 95\% Cl) & $0.35[0.14,0.86]$ \\
\hline 3.1 RCT data - nitroderivatives & 2 & 366 & Odds Ratio (M-H, Random, 95\% Cl) & $0.09[0.04,0.18]$ \\
\hline 3.2 RCT data - allopurinol & 2 & 75 & Odds Ratio (M-H, Random, 95\% Cl) & $0.58[0.19,1.74]$ \\
\hline 3.3 Non-RCT data & 2 & 632 & Odds Ratio (M-H, Random, 95\% Cl) & $0.72[0.33,1.57]$ \\
\hline $\begin{array}{l}4 \text { Mean reduction of antibodies } \\
\text { titres: all populations, all test- } \\
\text { ed drugs }\end{array}$ & 3 & 225 & Std. Mean Difference (IV, Random, 95\% CI) & $-0.56[-0.89,-0.23]$ \\
\hline 4.1 Benznidazole children & 2 & 200 & Std. Mean Difference (IV, Random, 95\% CI) & $-0.67[-0.96,-0.39]$ \\
\hline 4.2 Allopurinol adults & 1 & 25 & Std. Mean Difference (IV, Random, 95\% CI) & $0.04[-0.75,0.82]$ \\
\hline
\end{tabular}

Analysis 1.1. Comparison 1 Parasite-related outcomes, Outcome 1 Positive serology.

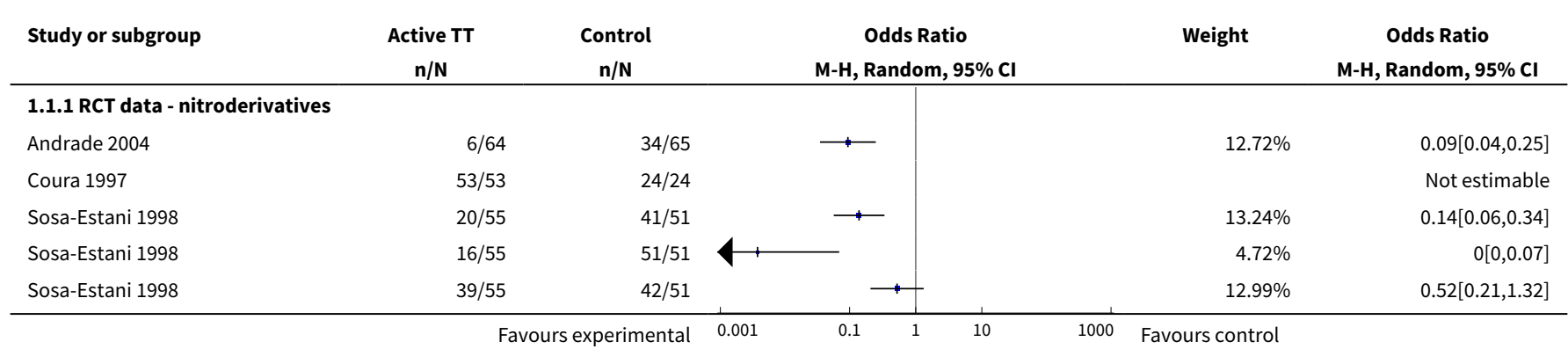




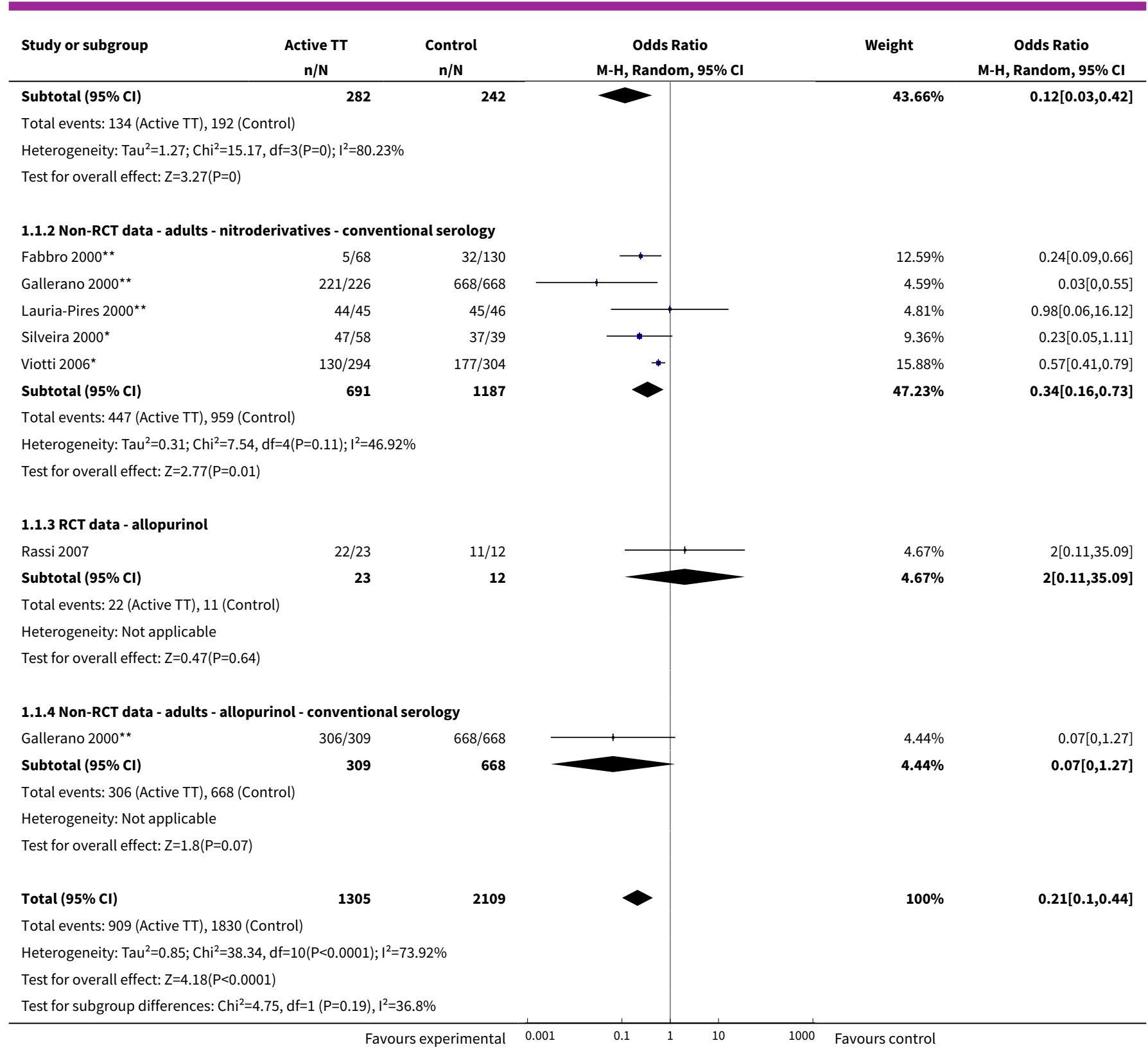

Analysis 1.2. Comparison 1 Parasite-related outcomes, Outcome 2 Positive PCR: nitroderivatives.

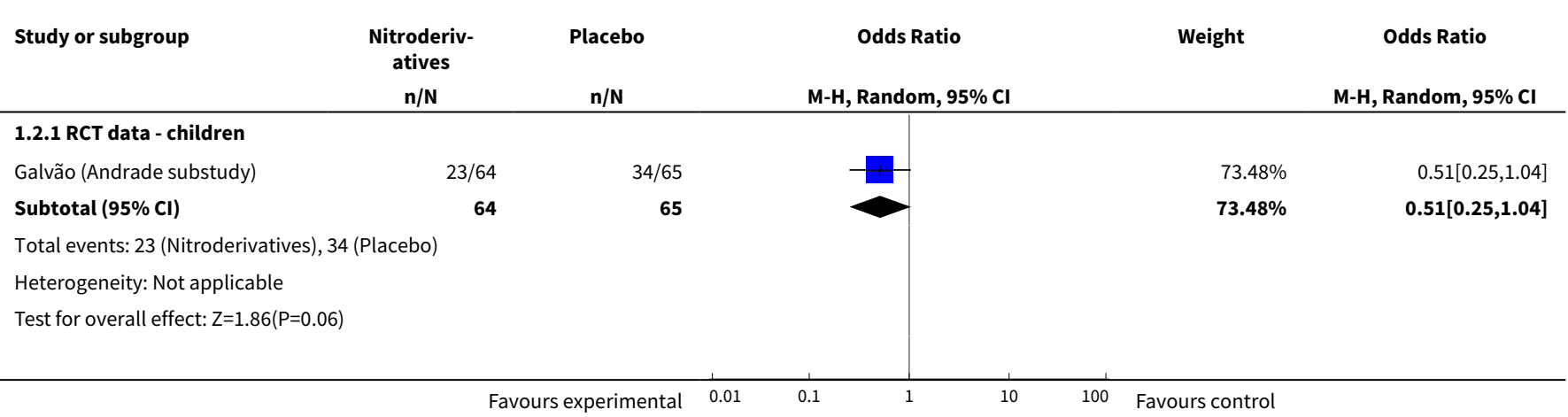




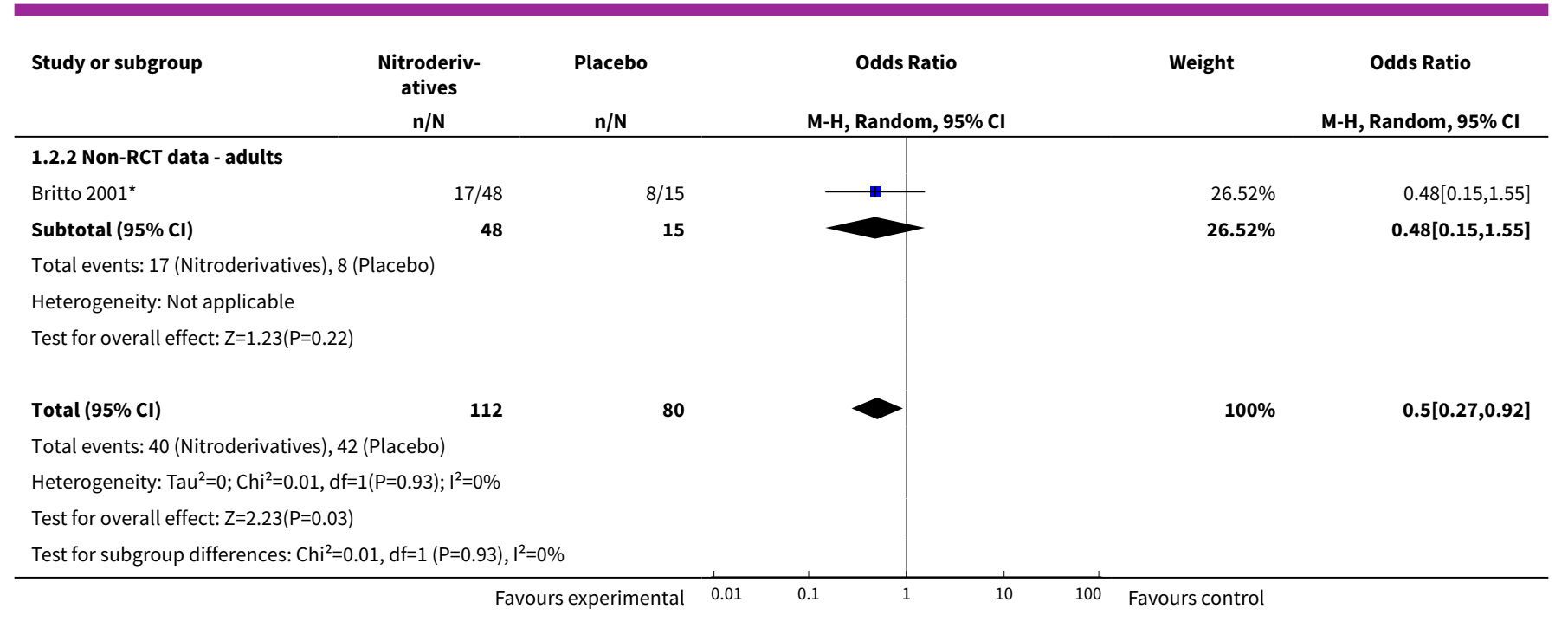

\section{Analysis 1.3. Comparison 1 Parasite-related outcomes, Outcome 3 Positive xenodiagnosis: all populations, all tested drugs.}

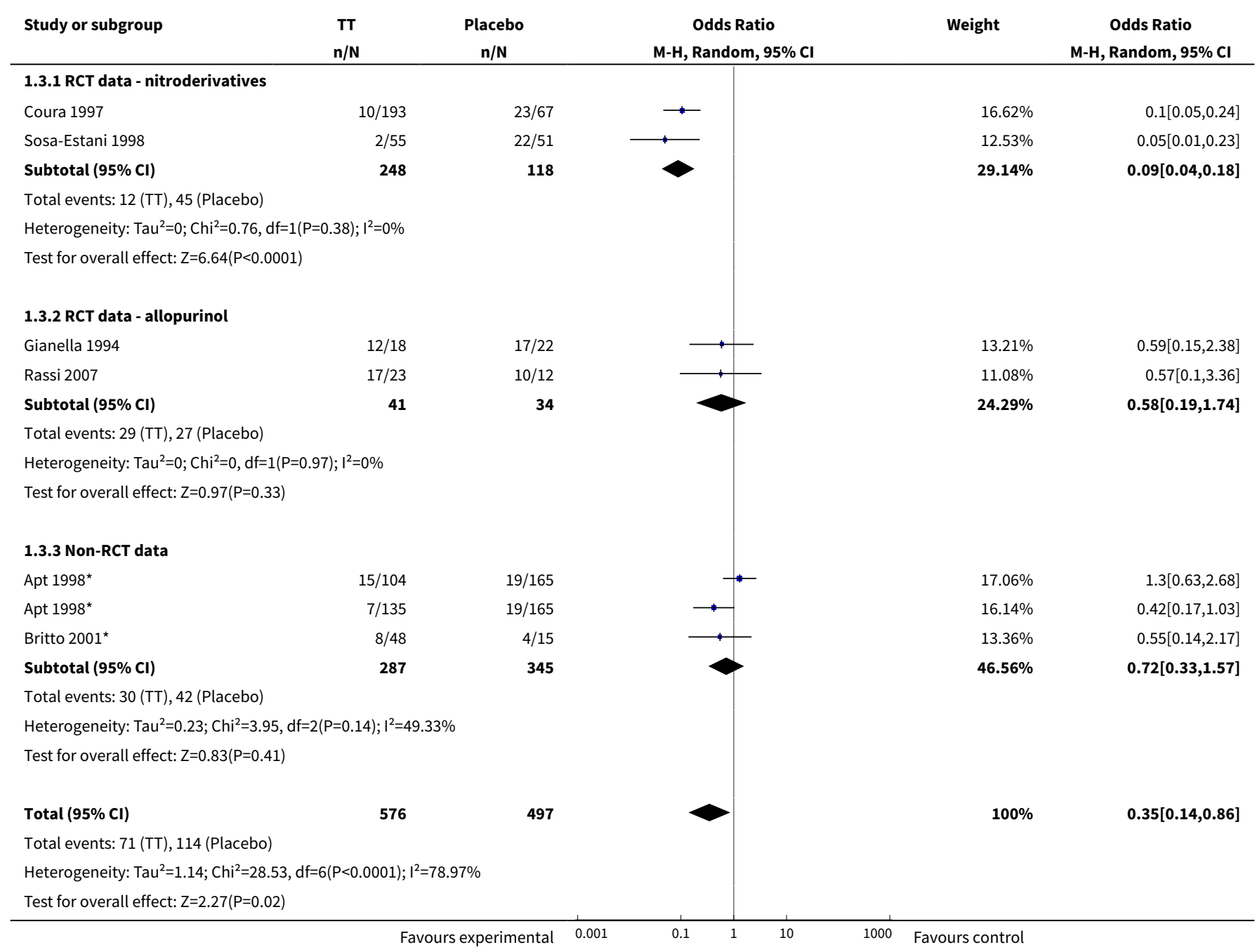




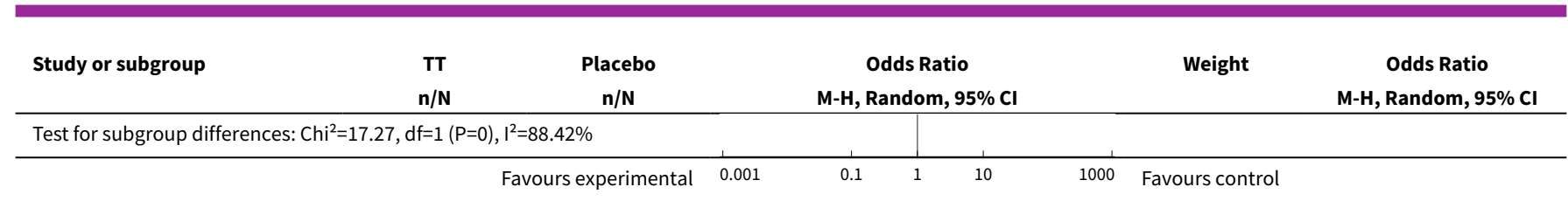

Analysis 1.4. Comparison 1 Parasite-related outcomes, Outcome 4 Mean reduction of antibodies titres: all populations, all tested drugs.

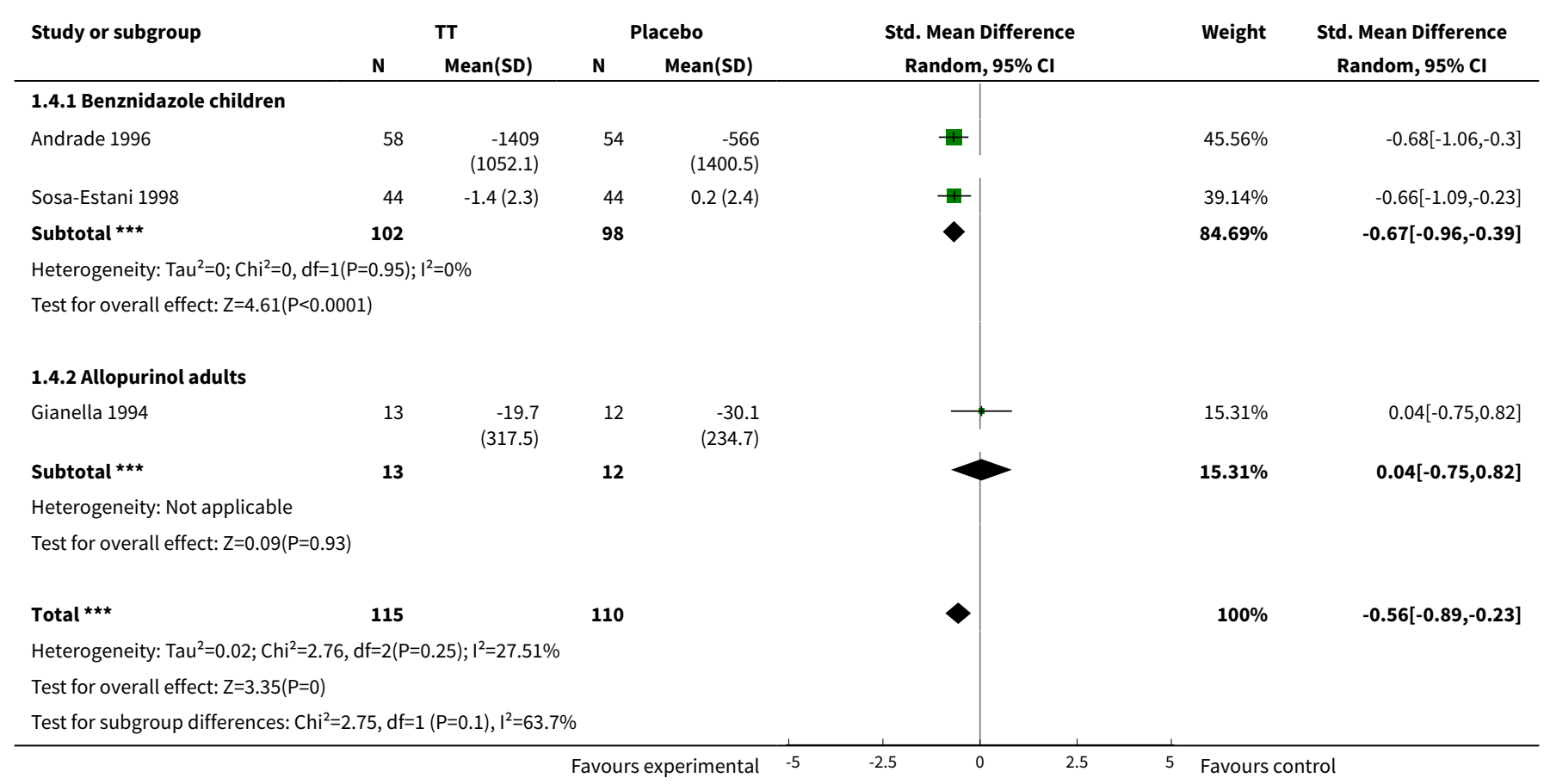

\section{Comparison 2. Patient-related outcomes: efficacy}

\begin{tabular}{lllll}
\hline Outcome or subgroup title & $\begin{array}{l}\text { No. of } \\
\text { studies }\end{array}$ & $\begin{array}{l}\text { No. of } \\
\text { partici- } \\
\text { pants }\end{array}$ & Statistical method & Effect size \\
\hline $\begin{array}{l}1 \text { ECG abnormalities - RCT data - ben- } \\
\text { znidazole }\end{array}$ & 2 & 235 & Odds Ratio (M-H, Random, 95\% Cl) & $0.41[0.07,2.31]$ \\
\hline $\begin{array}{l}\text { 2 Progression of cardiomyopathy: non- } \\
\text { RCT data - adults, nitroderivatives }\end{array}$ & 4 & 986 & Odds Ratio (M-H, Random, 95\% Cl) & $0.74[0.32,1.73]$ \\
\hline $\begin{array}{l}\text { 3 Mortality: non-RCT data - adults, all } \\
\text { tested drugs }\end{array}$ & 6 & 3396 & Odds Ratio (M-H, Random, 95\% Cl) & $0.55[0.26,1.14]$ \\
\hline $\begin{array}{l}\text { 3.1 Nitroderivatives } \\
\text { 3.2 Allopurinol }\end{array}$ & 6 & 2419 & Odds Ratio (M-H, Random, 95\% Cl) & $0.66[0.28,1.56]$ \\
\hline
\end{tabular}


Analysis 2.1. Comparison 2 Patient-related outcomes: efficacy,

Outcome 1 ECG abnormalities - RCT data - benznidazole.

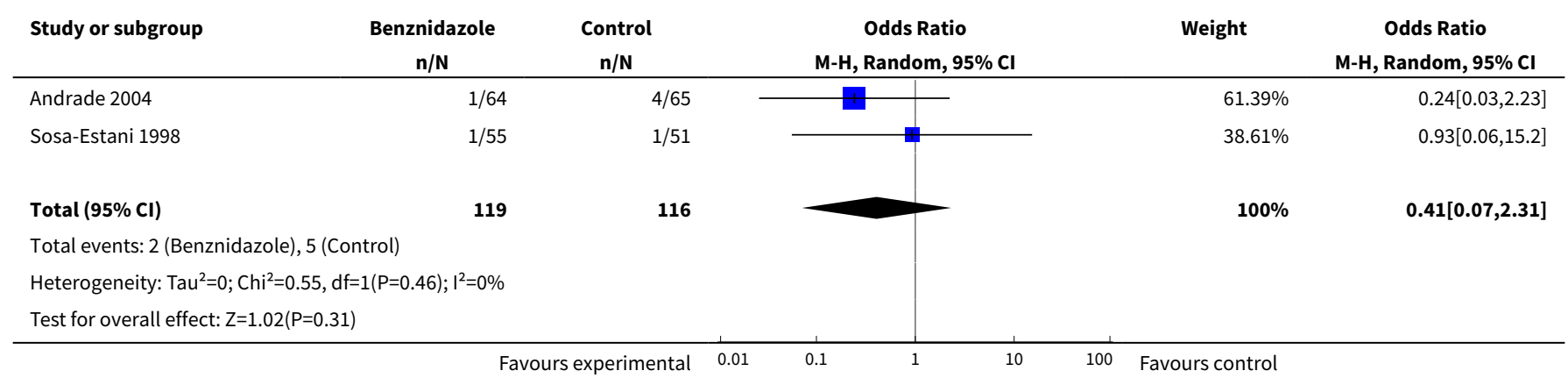

Analysis 2.2. Comparison 2 Patient-related outcomes: efficacy, Outcome 2 Progression of cardiomyopathy: non-RCT data - adults, nitroderivatives.

\begin{tabular}{|c|c|c|c|c|c|}
\hline Study or subgroup & $\begin{array}{c}\mathrm{TT} \\
\mathrm{n} / \mathrm{N}\end{array}$ & $\begin{array}{c}\text { Control } \\
\mathbf{n} / \mathbf{N}\end{array}$ & $\begin{array}{c}\text { Odds Ratio } \\
\text { M-H, Random, } 95 \% \mathrm{Cl}\end{array}$ & Weight & $\begin{array}{c}\text { Odds Ratio } \\
\text { M-H, Random, } 95 \% \text { Cl }\end{array}$ \\
\hline Fabbro $2000^{\star \star}$ & $4 / 70$ & $10 / 130$ & $\longrightarrow$ & $21.69 \%$ & $0.73[0.22,2.41]$ \\
\hline Lauria-Pires $2000^{\star \star}$ & $23 / 45$ & $21 / 46$ & $\longrightarrow$ & $28.1 \%$ & $1.24[0.55,2.84]$ \\
\hline Silveira $2000^{\star}$ & $12 / 58$ & $6 / 39$ & + & $23.65 \%$ & $1.43[0.49,4.21]$ \\
\hline Viotti 2006* & $6 / 294$ & $24 / 304$ & $\longrightarrow$ & $26.56 \%$ & $0.24[0.1,0.6]$ \\
\hline Total $(95 \% \mathrm{Cl})$ & 467 & 519 & & $100 \%$ & $0.74[0.32,1.73]$ \\
\hline \multicolumn{6}{|c|}{ Total events: 45 (TT), 61 (Control) } \\
\hline \multicolumn{6}{|c|}{ Heterogeneity: $\mathrm{Tau}^{2}=0.49 ; \mathrm{Chi}^{2}=8.82, \mathrm{df}=3(\mathrm{P}=0.03) ; \mathrm{I}^{2}=66 \%$} \\
\hline \multicolumn{6}{|c|}{ Test for overall effect: $Z=0.69(P=0.49)$} \\
\hline
\end{tabular}

Analysis 2.3. Comparison 2 Patient-related outcomes: efficacy, Outcome 3 Mortality: non-RCT data - adults, all tested drugs.

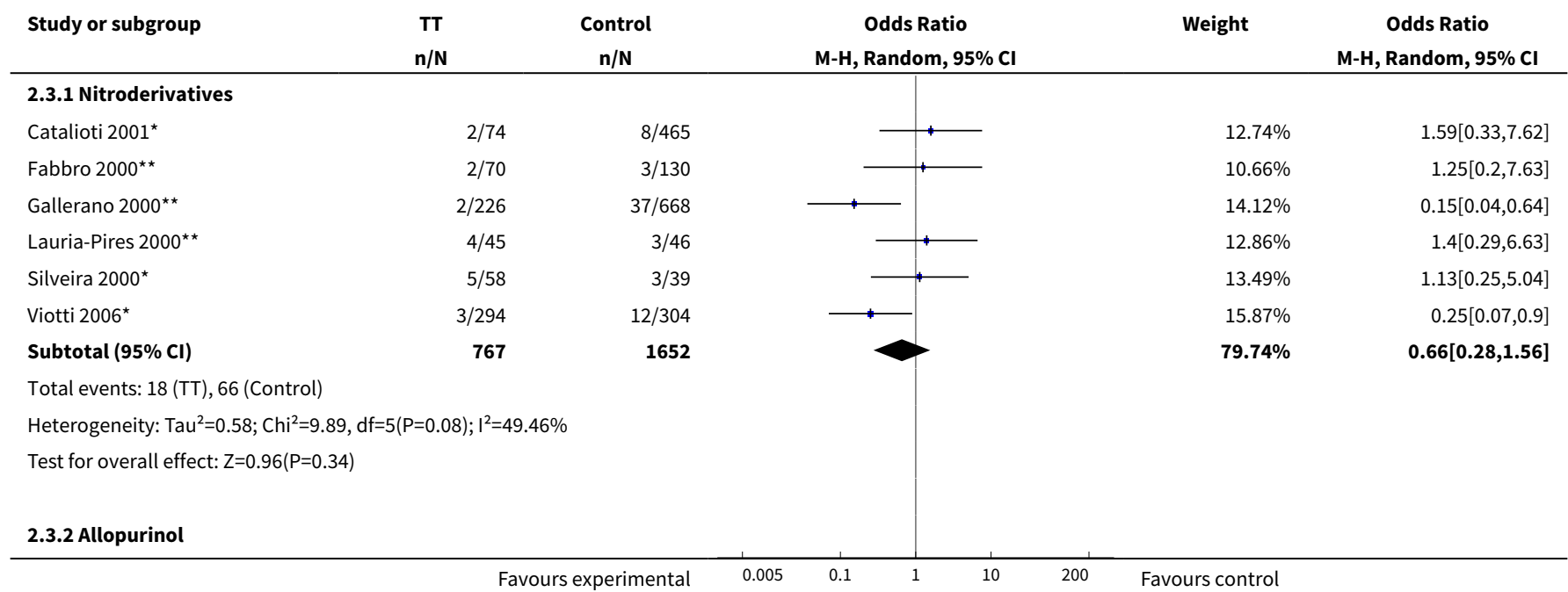




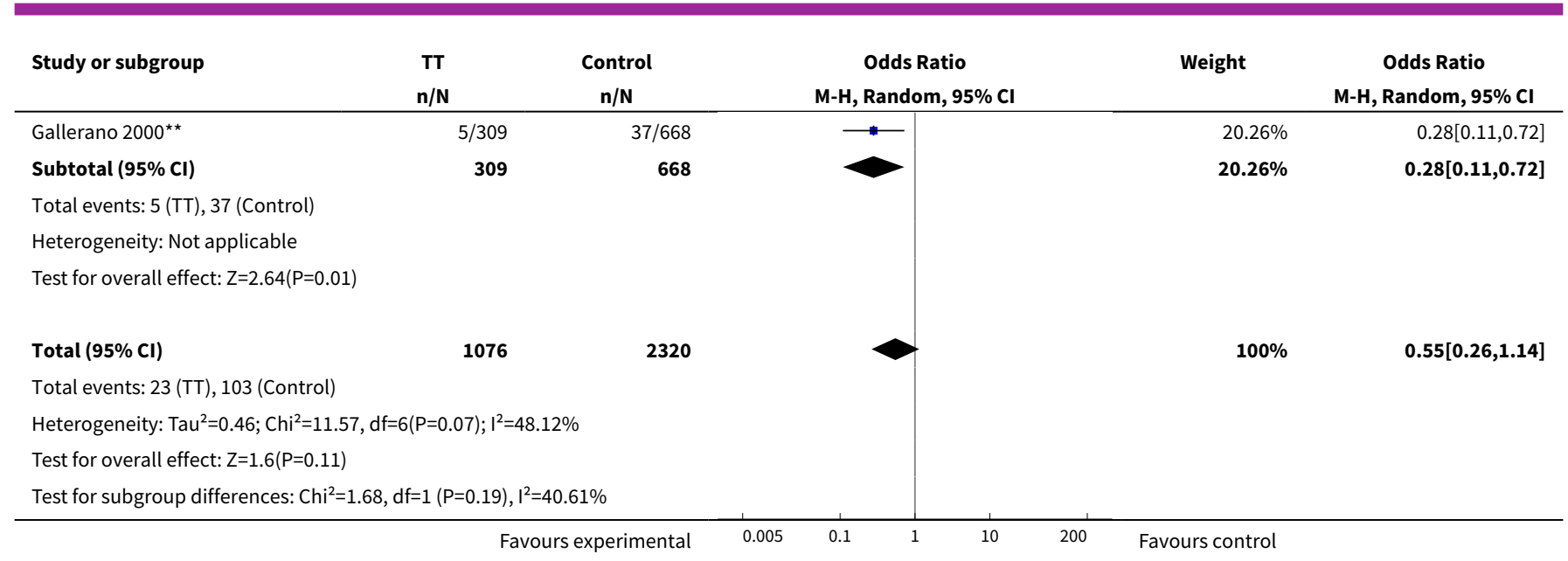

\section{Comparison 3. Patient-related outcomes: safety}

\begin{tabular}{|c|c|c|c|c|}
\hline Outcome or subgroup title & $\begin{array}{l}\text { No. of } \\
\text { studies }\end{array}$ & $\begin{array}{l}\text { No. of } \\
\text { partici- } \\
\text { pants }\end{array}$ & Statistical method & Effect size \\
\hline $\begin{array}{l}1 \text { BZD mild-to-moderate - RCT } \\
\text { data only }\end{array}$ & 2 & 3651 & Odds Ratio (M-H, Random, 95\% Cl) & $3.84[1.74,8.44]$ \\
\hline 1.1 Pruritus & 1 & 709 & Odds Ratio (M-H, Random, 95\% Cl) & $3.83[2.41,6.08]$ \\
\hline 1.2 Mild rash & 1 & 709 & Odds Ratio (M-H, Random, 95\% Cl) & $7.59[4.79,12.03]$ \\
\hline 1.3 Moderate rash & 1 & 709 & Odds Ratio (M-H, Random, 95\% Cl) & $7.78[4.15,14.61]$ \\
\hline 1.4 Unspecified & 1 & 106 & Odds Ratio (M-H, Random, 95\% Cl) & $13.53[0.74,246.49]$ \\
\hline 1.5 Headache & 1 & 709 & Odds Ratio (M-H, Random, 95\% Cl) & $1.22[0.85,1.75]$ \\
\hline 1.6 Insomnia & 1 & 709 & Odds Ratio (M-H, Random, 95\% Cl) & $2.08[0.88,4.92]$ \\
\hline 3 BZD severe side effects & 3 & 9208 & Odds Ratio (M-H, Random, 95\% Cl) & $12.02[6.07,23.80]$ \\
\hline 3.1 Toxic hepatitis & 2 & 1507 & Odds Ratio (M-H, Random, 95\% Cl) & $15.19[1.84,125.09]$ \\
\hline 3.2 Arthritis & 1 & 709 & Odds Ratio (M-H, Random, 95\% Cl) & $10.41[1.33,81.75]$ \\
\hline 3.3 Peripheral neuropathy & 2 & 1507 & Odds Ratio (M-H, Random, 95\% Cl) & $11.69[2.07,66.19]$ \\
\hline 3.4 Lymphadenopathy & 1 & 709 & Odds Ratio (M-H, Random, 95\% Cl) & $19.77[1.15,341.06]$ \\
\hline 3.5 Oedema & 1 & 709 & Odds Ratio (M-H, Random, 95\% Cl) & $4.02[1.48,10.88]$ \\
\hline 3.6 Fever & 2 & 1275 & Odds Ratio (M-H, Random, 95\% Cl) & $10.35[1.87,57.36]$ \\
\hline 3.7 Severe skin reactions & 2 & 1396 & Odds Ratio (M-H, Random, 95\% Cl) & $142.68[19.64,1036.38]$ \\
\hline $\begin{array}{l}\text { 3.8 Severe gastrointestinal in- } \\
\text { tolerance }\end{array}$ & 2 & 1396 & Odds Ratio (M-H, Random, 95\% Cl) & $15.36[1.86,126.55]$ \\
\hline
\end{tabular}




\begin{tabular}{|c|c|c|c|c|}
\hline Outcome or subgroup title & $\begin{array}{l}\text { No. of } \\
\text { studies }\end{array}$ & $\begin{array}{l}\text { No. of } \\
\text { partici- } \\
\text { pants }\end{array}$ & Statistical method & Effect size \\
\hline $\begin{array}{l}5 \text { ALLOP - mild-to-moderate - } \\
\text { RCT data only }\end{array}$ & 2 & 355 & Odds Ratio (M-H, Random, 95\% Cl) & $1.89[0.74,4.85]$ \\
\hline 5.1 Pyrosis & 1 & 35 & Odds Ratio (M-H, Random, 95\% Cl) & $4.27[0.20,89.72]$ \\
\hline 5.2 Vertigo & 1 & 35 & Odds Ratio (M-H, Random, 95\% Cl) & $0.16[0.01,4.32]$ \\
\hline 5.3 Rash & 2 & 75 & Odds Ratio (M-H, Random, 95\% Cl) & $2.23[0.41,12.19]$ \\
\hline 5.4 Leukopenia & 1 & 35 & Odds Ratio (M-H, Random, 95\% Cl) & $2.91[0.13,65.53]$ \\
\hline 5.5 Lymph node increase & 1 & 35 & Odds Ratio (M-H, Random, 95\% Cl) & $1.67[0.06,44.05]$ \\
\hline 5.6 Vomit & 1 & 35 & Odds Ratio (M-H, Random, 95\% Cl) & $1.67[0.06,44.05]$ \\
\hline 5.7 Stomach ache & 1 & 35 & Odds Ratio (M-H, Random, 95\% Cl) & $1.67[0.06,44.05]$ \\
\hline 5.8 Red Eye & 1 & 35 & Odds Ratio (M-H, Random, 95\% Cl) & $1.67[0.06,44.05]$ \\
\hline 5.9 Pruritus & 1 & 35 & Odds Ratio (M-H, Random, 95\% Cl) & $4.27[0.20,89.72]$ \\
\hline 6 ALLOP - severe side effects & 4 & 2298 & Odds Ratio (M-H, Random, 95\% Cl) & $12.34[3.23,47.04]$ \\
\hline 6.1 Skin severe reactions & 3 & 1286 & Odds Ratio (M-H, Random, 95\% Cl) & $12.42[2.17,71.02]$ \\
\hline 6.2 Fever & 1 & 35 & Odds Ratio (M-H, Random, 95\% Cl) & $7.43[0.38,146.72]$ \\
\hline $\begin{array}{l}6.3 \text { Severe gastrointestinal ef- } \\
\text { fects }\end{array}$ & 1 & 977 & Odds Ratio (M-H, Random, 95\% Cl) & $19.69[1.06,366.94]$ \\
\hline 7 NFTMX - severe side effects & 1 & 3056 & Odds Ratio (M-H, Random, 95\% Cl) & $81.75[18.97,352.35]$ \\
\hline 7.1 Polyneuritis & 1 & 764 & Odds Ratio (M-H, Random, 95\% Cl) & $35.37[1.69,742.39]$ \\
\hline 7.2 Toxic hepatitis & 1 & 764 & Odds Ratio (M-H, Random, 95\% Cl) & $179.83[10.50,3079.04]$ \\
\hline 7.3 Malaise & 1 & 764 & Odds Ratio (M-H, Random, 95\% Cl) & $96.03[5.36,1718.90]$ \\
\hline 7.4 Severe skin reactions & 1 & 764 & Odds Ratio (M-H, Random, 95\% Cl) & $65.04[3.47,1217.89]$ \\
\hline 8 ITRA - severe side effects & 1 & 300 & Odds Ratio (M-H, Random, 95\% Cl) & $3.69[0.15,91.35]$ \\
\hline $\begin{array}{l}9 \text { Drug discontinuation - all pop- } \\
\text { ulations, all drugs }\end{array}$ & 10 & 4385 & Odds Ratio (M-H, Random, 95\% Cl) & $11.84[3.14,44.70]$ \\
\hline 9.1 RCT data & 5 & 1056 & Odds Ratio (M-H, Random, 95\% Cl) & $2.65[0.40,17.66]$ \\
\hline 9.2 Non-RCT data & 5 & 3329 & Odds Ratio (M-H, Random, 95\% Cl) & $42.48[13.78,130.95]$ \\
\hline
\end{tabular}


Analysis 3.1. Comparison 3 Patient-related outcomes: safety, Outcome 1 BZD mild-to-moderate - RCT data only.

Benznidazole

$\mathbf{n} / \mathbf{N}$

$84 / 352$

352

Subtotal $(95 \% \mathrm{CI})$

Total events: 84 (Benznidazole), 27 (Control)

Heterogeneity: Not applicable

Test for overall effect: $Z=5.69(P<0.0001)$

\subsubsection{Mild rash}

Prado 2008

Subtotal $(95 \% \mathrm{Cl})$

Total events: 128 (Benznidazole), 25 (Control)

Heterogeneity: Not applicable

Test for overall effect: $Z=8.62(P<0.0001)$

\subsubsection{Moderate rash}

Prado 2008

Subtotal $(95 \% \mathrm{CI})$

Total events: 75 (Benznidazole), 12 (Control)

Heterogeneity: Not applicable

Test for overall effect: $Z=6.39(P<0.0001)$

\subsubsection{Unspecified}

Sosa-Estani 1998

Subtotal $(95 \% \mathrm{CI})$

Total events: 6 (Benznidazole), 0 (Control)

Heterogeneity: Not applicable

Test for overall effect: $Z=1.76(P=0.08)$

\subsubsection{Headache}

Prado 2008

Subtotal $(95 \% \mathrm{Cl})$

$83 / 352$

352

$72 / 357$

$0 / 51$

Odds Ratio

$\mathrm{n} / \mathrm{N}$

M-H, Random, 95\% Cl

M-H, Random, $95 \% \mathrm{Cl}$

Total events: 83 (Benznidazole), 72 (Control)

Heterogeneity: Not applicable

Test for overall effect: $Z=1.1(P=0.27)$

3.1.6 Insomnia

Prado 2008

Subtotal $(95 \% \mathrm{Cl})$

Total events: 16 (Benznidazole), 8 (Control)

Heterogeneity: Not applicable

Test for overall effect: $Z=1.66(P=0.1)$

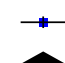

$19.58 \%$

$19.58 \%$

$7.59[4.79,12.03]$

$7.59[4.79,12.03]$

$7.78[4.15,14.61]$

$18.51 \%$

$7.78[4.15,14.61]$

$13.53[0.74,246.49]$

$5.46 \%$

$13.53[0.74,246.49]$
Total events: 392 (Benznidazole), 144 (Control) Heterogeneity: $\mathrm{Tau}^{2}=0.77 ; \mathrm{Chi}^{2}=51.97, \mathrm{df}=5(\mathrm{P}<0.0001) ; \mathrm{I}^{2}=90.38 \%$ Test for overall effect: $Z=3.34(P=0)$

Test for subgroup differences: $\mathrm{Chi}^{2}=51.49, \mathrm{df}=1(\mathrm{P}<0.0001), \mathrm{I}^{2}=90.29 \%$ 
Analysis 3.3. Comparison 3 Patient-related outcomes: safety, Outcome 3 BZD severe side effects.

\begin{tabular}{|c|c|c|c|c|c|}
\hline Study or subgroup & $\begin{array}{c}\text { Benznidazole } \\
\mathrm{n} / \mathrm{N} \\
\end{array}$ & $\begin{array}{c}\text { Control } \\
\mathrm{n} / \mathrm{N}\end{array}$ & $\begin{array}{c}\text { Odds Ratio } \\
\text { M-H, Random, } 95 \% \mathrm{Cl}\end{array}$ & Weight & $\begin{array}{c}\text { Odds Ratio } \\
\text { M-H, Random, } 95 \% \mathrm{Cl}\end{array}$ \\
\hline \multicolumn{6}{|l|}{ 3.3.1 Toxic hepatitis } \\
\hline Gallerano $2000^{\star \star}$ & $2 / 130$ & $0 / 668$ & $\longrightarrow$ & $4.68 \%$ & $26.01[1.24,544.99]$ \\
\hline Prado 2008 & $4 / 352$ & $0 / 357$ & & $5.03 \%$ & $9.23[0.5,172.12]$ \\
\hline Subtotal $(95 \% \mathrm{Cl})$ & 482 & 1025 & & $9.71 \%$ & $15.19[1.84,125.09]$ \\
\hline \multicolumn{6}{|c|}{ Total events: 6 (Benznidazole), 0 (Control) } \\
\hline \multicolumn{6}{|c|}{ Test for overall effect: $Z=2.53(P=0.01)$} \\
\hline \multicolumn{6}{|l|}{ 3.3.2 Arthritis } \\
\hline Prado 2008 & $10 / 352$ & $1 / 357$ & $\longrightarrow$ & $9.41 \%$ & $10.41[1.33,81.75]$ \\
\hline Subtotal $(95 \% \mathrm{Cl})$ & 352 & 357 & & $9.41 \%$ & $10.41[1.33,81.75]$ \\
\hline \multicolumn{6}{|c|}{ Total events: 10 (Benznidazole), 1 (Control) } \\
\hline \multicolumn{6}{|c|}{ Test for overall effect: $Z=2.23(P=0.03)$} \\
\hline \multicolumn{6}{|c|}{ 3.3.3 Peripheral neuropathy } \\
\hline Gallerano $2000^{\star \star}$ & $1 / 130$ & $0 / 668$ & & $4.24 \%$ & $15.49[0.63,382.26]$ \\
\hline Prado 2008 & $10 / 352$ & $1 / 357$ & - & $9.41 \%$ & $10.41[1.33,81.75]$ \\
\hline Subtotal $(95 \% \mathrm{Cl})$ & 482 & 1025 & & $13.65 \%$ & $11.69[2.07,66.19]$ \\
\hline
\end{tabular}

Total events: 11 (Benznidazole), 1 (Control)

Heterogeneity: $\mathrm{Tau}^{2}=0 ; \mathrm{Chi}^{2}=0.04, \mathrm{df}=1(\mathrm{P}=0.83) ; \mathrm{I}^{2}=0 \%$

Test for overall effect: $Z=2.78(P=0.01)$

\subsubsection{Lymphadenopathy}

Prado 2008

Subtotal $(95 \% \mathrm{Cl})$

Total events: 9 (Benznidazole), 0 (Control)

Heterogeneity: Not applicable

Test for overall effect: $Z=2.05(P=0.04)$

\subsubsection{Oedema}

Prado 2008

Subtotal $(95 \% \mathrm{Cl})$

Total events: 19 (Benznidazole), 5 (Control)

Heterogeneity: Not applicable

Test for overall effect: $Z=2.74(P=0.01)$

\subsubsection{Fever}

Prado 2008

Viotti $2006^{\star}$

Total events: 17 (Benznidazole), 1 (Control) Heterogeneity: $\mathrm{Tau}^{2}=0 ; \mathrm{Chi}^{2}=0.83, \mathrm{df}=1(\mathrm{P}=0.36) ; \mathrm{I}^{2}=0 \%$ Test for overall effect: $Z=2.67(P=0.01)$

\subsubsection{Severe skin reactions}

Gallerano 2000**

Viotti 2006*

Subtotal $(95 \% \mathrm{Cl})$

$\begin{array}{rr}21 / 130 & 0 / 668 \\ 33 / 294 & 0 / 304 \\ \mathbf{4 2 4} & \mathbf{9 7 2}\end{array}$

Total events: 54 (Benznidazole), 0 (Control) 


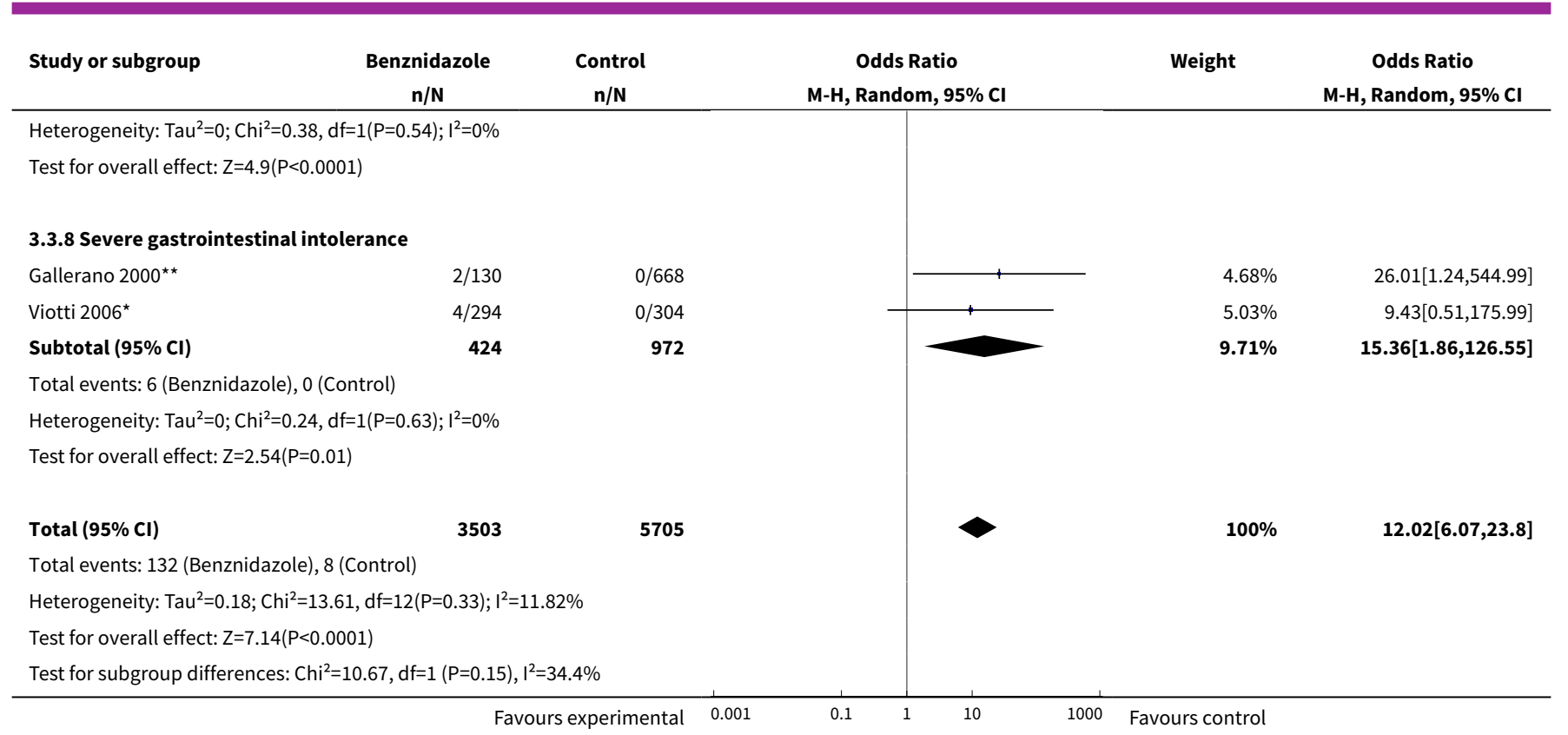

Analysis 3.5. Comparison 3 Patient-related outcomes: safety, Outcome 5 ALLOP - mild-to-moderate - RCT data only.

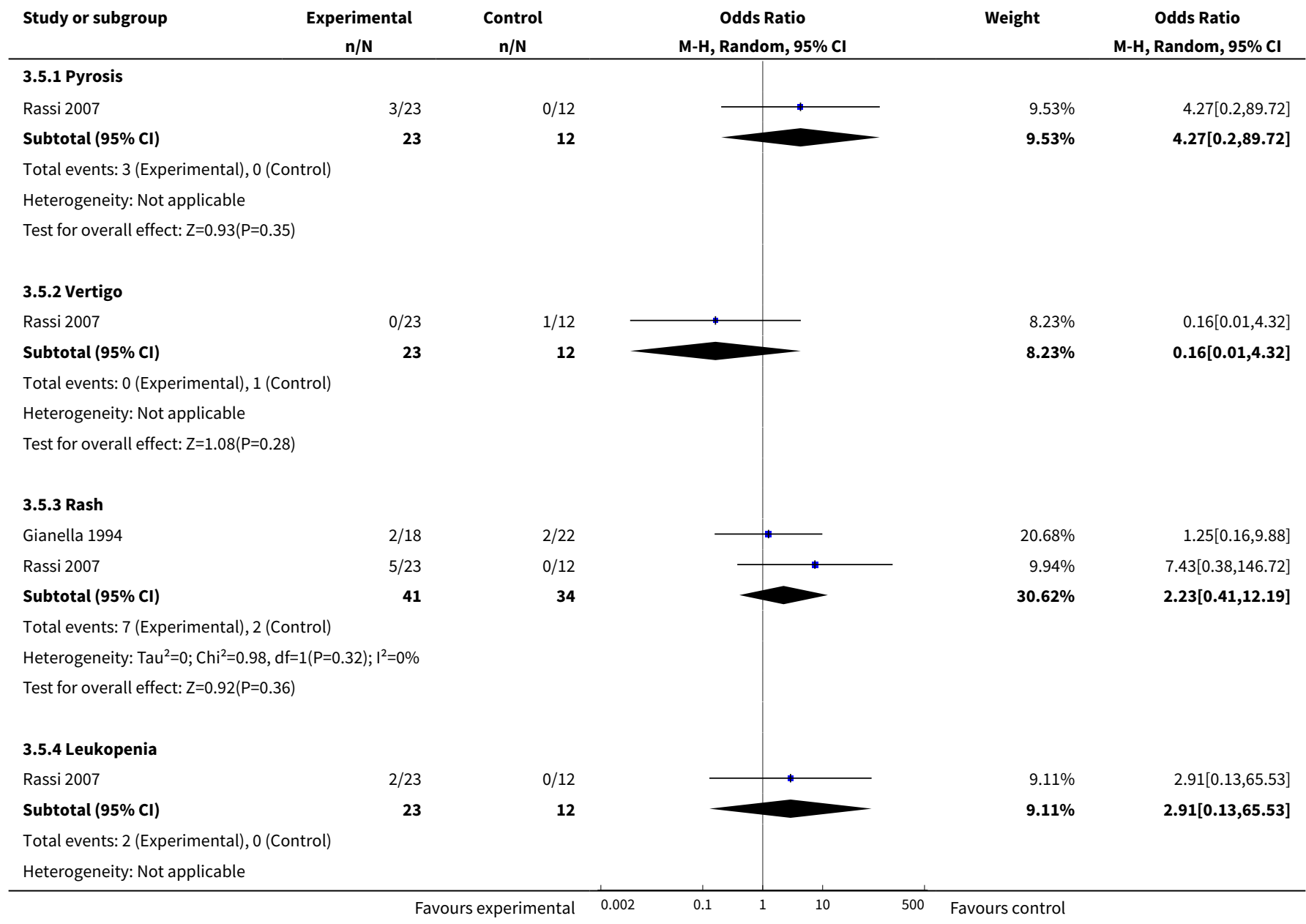




\begin{tabular}{|c|c|c|c|c|c|}
\hline Study or subgroup & $\begin{array}{c}\text { Experimental } \\
n / N\end{array}$ & $\begin{array}{c}\text { Control } \\
\mathrm{n} / \mathrm{N}\end{array}$ & $\begin{array}{c}\text { Odds Ratio } \\
\text { M-H, Random, } 95 \% \mathrm{CI}\end{array}$ & Weight & $\begin{array}{c}\text { Odds Ratio } \\
\text { M-H, Random, } 95 \% \mathrm{Cl}\end{array}$ \\
\hline \multicolumn{6}{|c|}{ Test for overall effect: $Z=0.67(P=0.5)$} \\
\hline \multicolumn{6}{|c|}{ 3.5.5 Lymph node increase } \\
\hline Rassi 2007 & $1 / 23$ & $0 / 12$ & 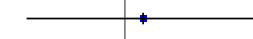 & $8.24 \%$ & $1.67[0.06,44.05]$ \\
\hline Subtotal $(95 \% \mathrm{Cl})$ & 23 & 12 & & $8.24 \%$ & $1.67[0.06,44.05]$ \\
\hline \multicolumn{6}{|c|}{ Total events: 1 (Experimental), 0 (Control) } \\
\hline \multicolumn{6}{|c|}{ Heterogeneity: Not applicable } \\
\hline \multicolumn{6}{|c|}{ Test for overall effect: $Z=0.31(P=0.76)$} \\
\hline \multicolumn{6}{|l|}{ 3.5.6 Vomit } \\
\hline Rassi 2007 & $1 / 23$ & $0 / 12$ & & $8.24 \%$ & $1.67[0.06,44.05]$ \\
\hline Subtotal $(95 \% \mathrm{CI})$ & 23 & 12 & & $8.24 \%$ & $1.67[0.06,44.05]$ \\
\hline \multicolumn{6}{|c|}{ Total events: 1 (Experimental), 0 (Control) } \\
\hline \multicolumn{6}{|c|}{ Heterogeneity: Not applicable } \\
\hline \multicolumn{6}{|c|}{ Test for overall effect: $Z=0.31(P=0.76)$} \\
\hline \multicolumn{6}{|l|}{ 3.5.7 Stomach ache } \\
\hline Rassi 2007 & $1 / 23$ & $0 / 12$ & 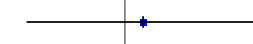 & $8.24 \%$ & $1.67[0.06,44.05]$ \\
\hline Subtotal $(95 \% \mathrm{Cl})$ & 23 & 12 & & $8.24 \%$ & $1.67[0.06,44.05]$ \\
\hline \multicolumn{6}{|c|}{ Total events: 1 (Experimental), 0 (Control) } \\
\hline \multicolumn{6}{|c|}{ Heterogeneity: Not applicable } \\
\hline \multicolumn{6}{|c|}{ Test for overall effect: $\mathrm{Z}=0.31(\mathrm{P}=0.76)$} \\
\hline \multicolumn{6}{|l|}{ 3.5.8 Red Eye } \\
\hline Rassi 2007 & $1 / 23$ & $0 / 12$ & 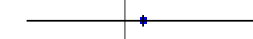 & $8.24 \%$ & $1.67[0.06,44.05]$ \\
\hline Subtotal $(95 \% \mathrm{Cl})$ & 23 & 12 & & $8.24 \%$ & $1.67[0.06,44.05]$ \\
\hline \multicolumn{6}{|c|}{ Total events: 1 (Experimental), 0 (Control) } \\
\hline \multicolumn{6}{|c|}{ Heterogeneity: Not applicable } \\
\hline \multicolumn{6}{|c|}{ Test for overall effect: $Z=0.31(P=0.76)$} \\
\hline \multicolumn{6}{|l|}{ 3.5.9 Pruritus } \\
\hline Rassi 2007 & $3 / 23$ & $0 / 12$ & & $9.53 \%$ & $4.27[0.2,89.72]$ \\
\hline Subtotal $(95 \% \mathrm{Cl})$ & 23 & 12 & & $9.53 \%$ & $4.27[0.2,89.72]$ \\
\hline \multicolumn{6}{|c|}{ Total events: 3 (Experimental), 0 (Control) } \\
\hline \multicolumn{6}{|c|}{ Heterogeneity: Not applicable } \\
\hline \multicolumn{6}{|c|}{ Test for overall effect: $Z=0.93(P=0.35)$} \\
\hline Total $(95 \% \mathrm{Cl})$ & 225 & 130 & & $100 \%$ & $1.89[0.74,4.85]$ \\
\hline \multicolumn{6}{|c|}{ Total events: 19 (Experimental), 3 (Control) } \\
\hline \multicolumn{6}{|c|}{ Heterogeneity: $\mathrm{Tau}^{2}=0 ; \mathrm{Chi}^{2}=3.78, \mathrm{df}=9(\mathrm{P}=0.93) ; \mathrm{I}^{2}=0 \%$} \\
\hline \multicolumn{6}{|c|}{ Test for overall effect: $Z=1.33(P=0.18)$} \\
\hline \multicolumn{6}{|c|}{ Test for subgroup differences: $\mathrm{Chi}^{2}=2.83, \mathrm{df}=1(\mathrm{P}=0.94), \mathrm{I}^{2}=0 \%$} \\
\hline
\end{tabular}

Analysis 3.6. Comparison 3 Patient-related outcomes: safety, Outcome 6 ALLOP - severe side effects.

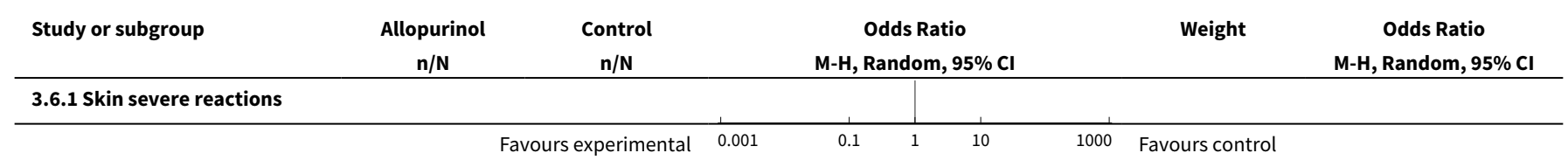




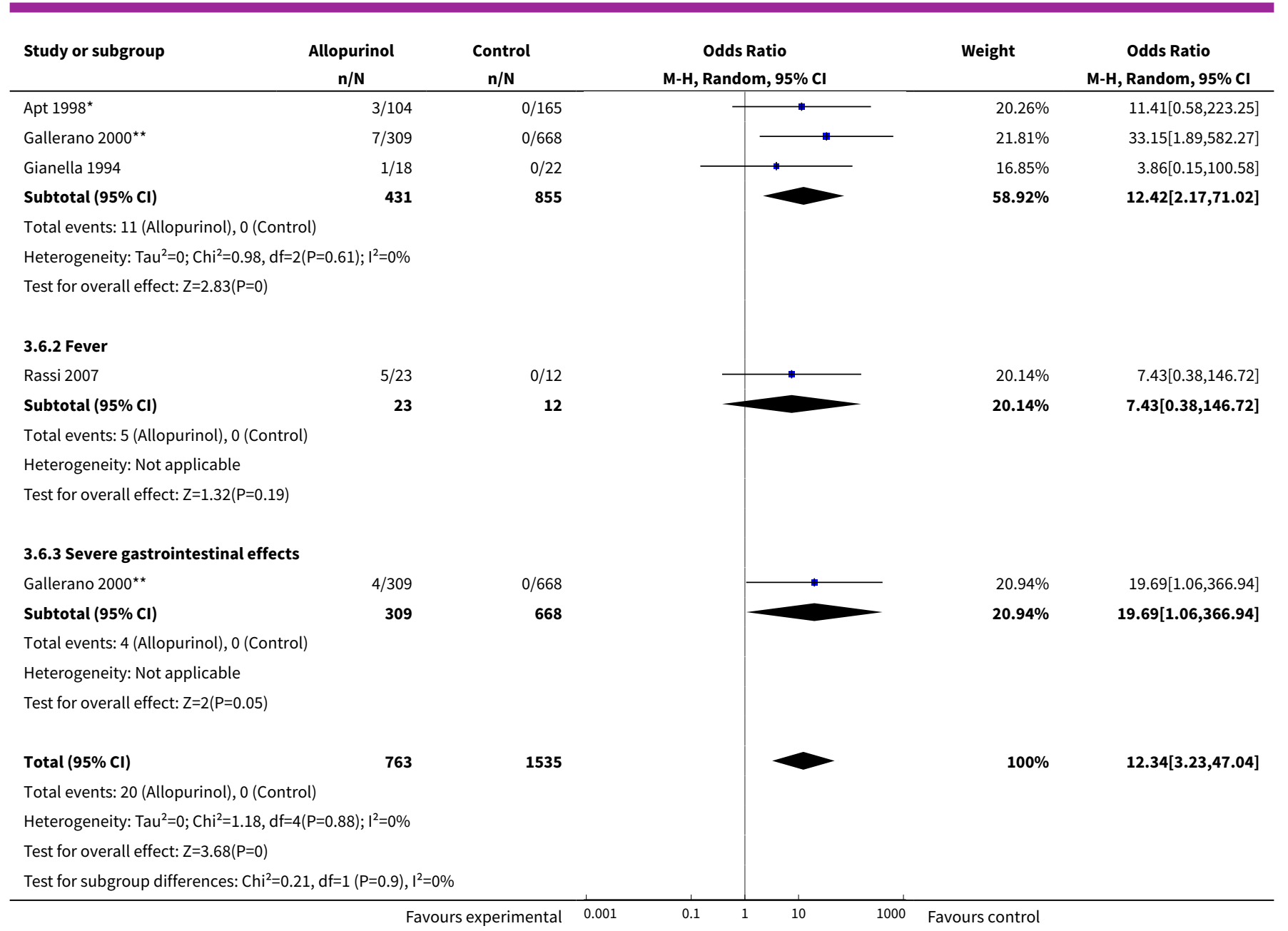

Analysis 3.7. Comparison 3 Patient-related outcomes: safety, Outcome 7 NFTMX - severe side effects.

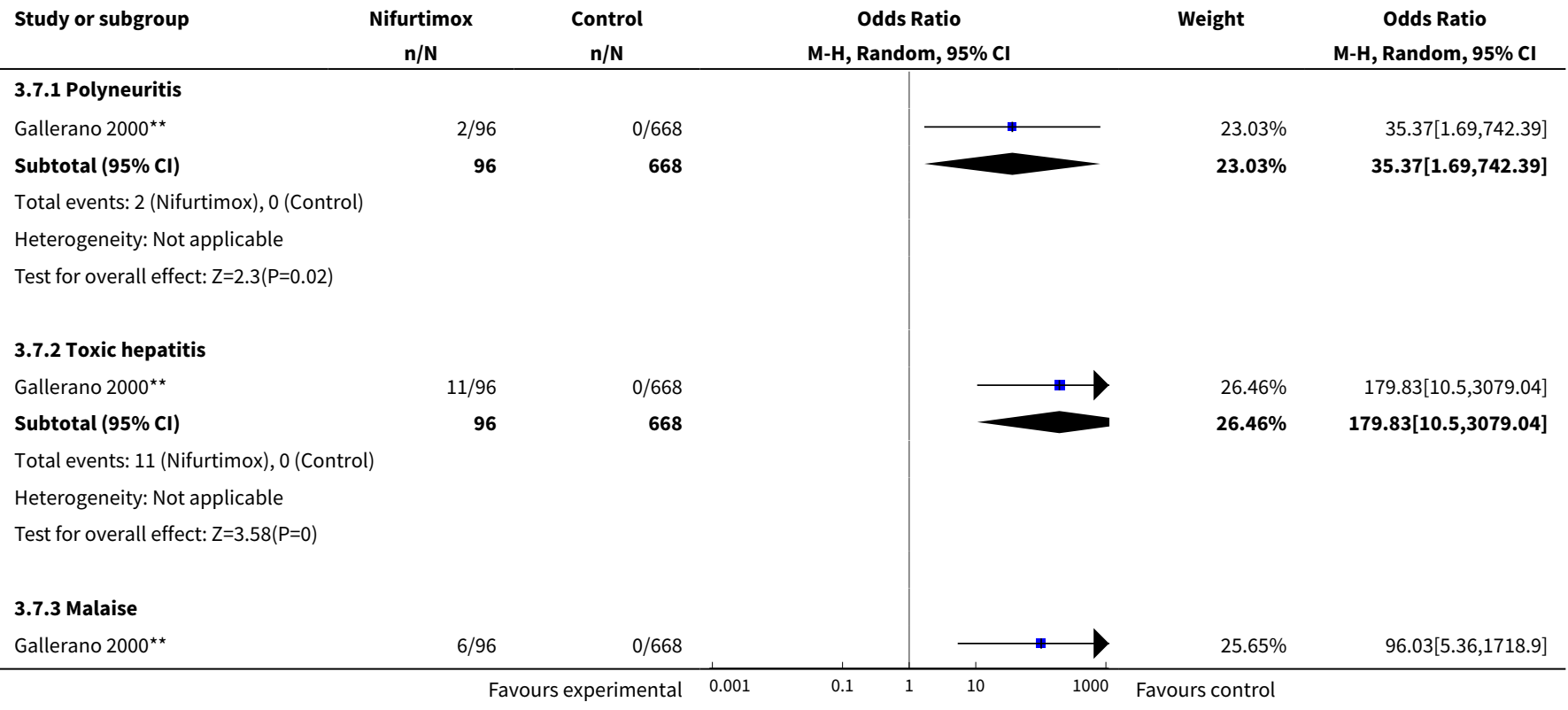




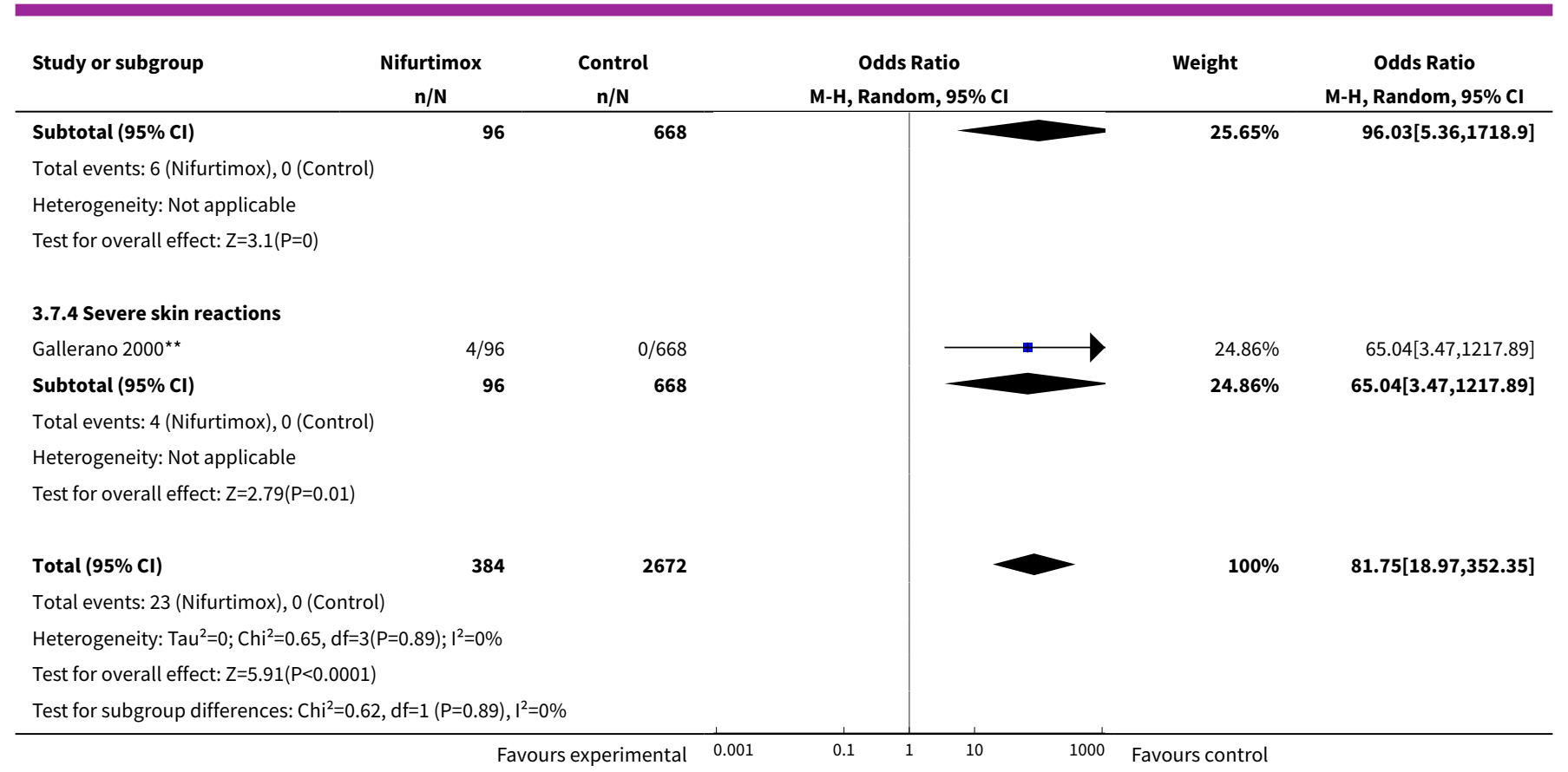

Analysis 3.8. Comparison 3 Patient-related outcomes: safety, Outcome 8 ITRA - severe side effects.

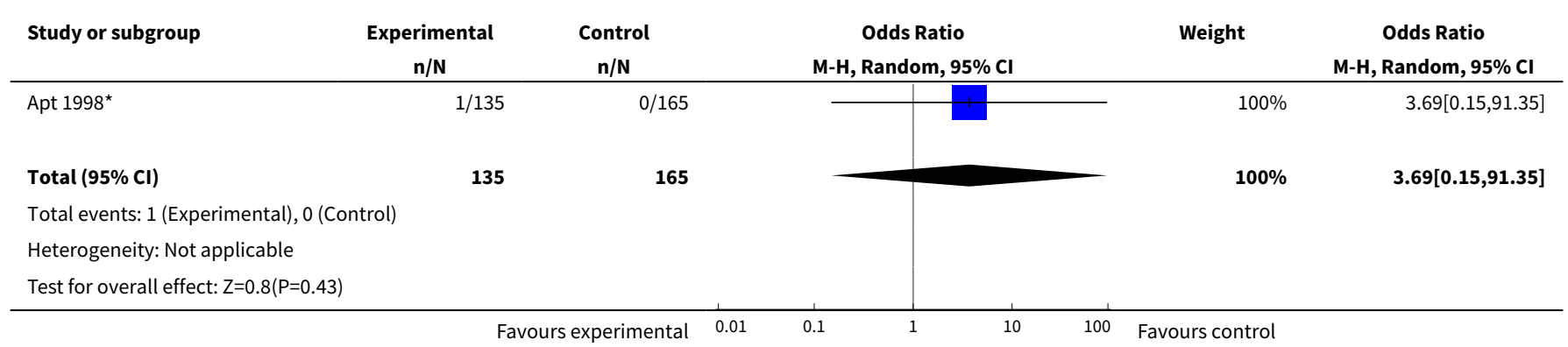

Analysis 3.9. Comparison 3 Patient-related outcomes: safety, Outcome 9 Drug discontinuation - all populations, all drugs.

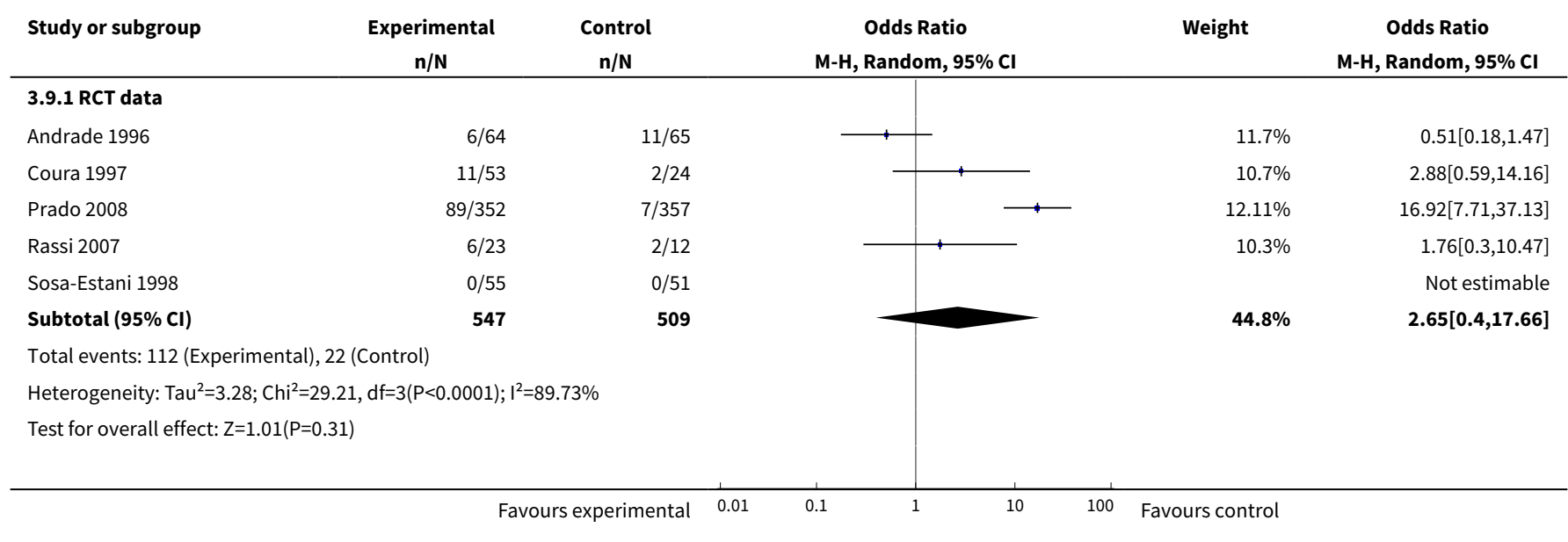




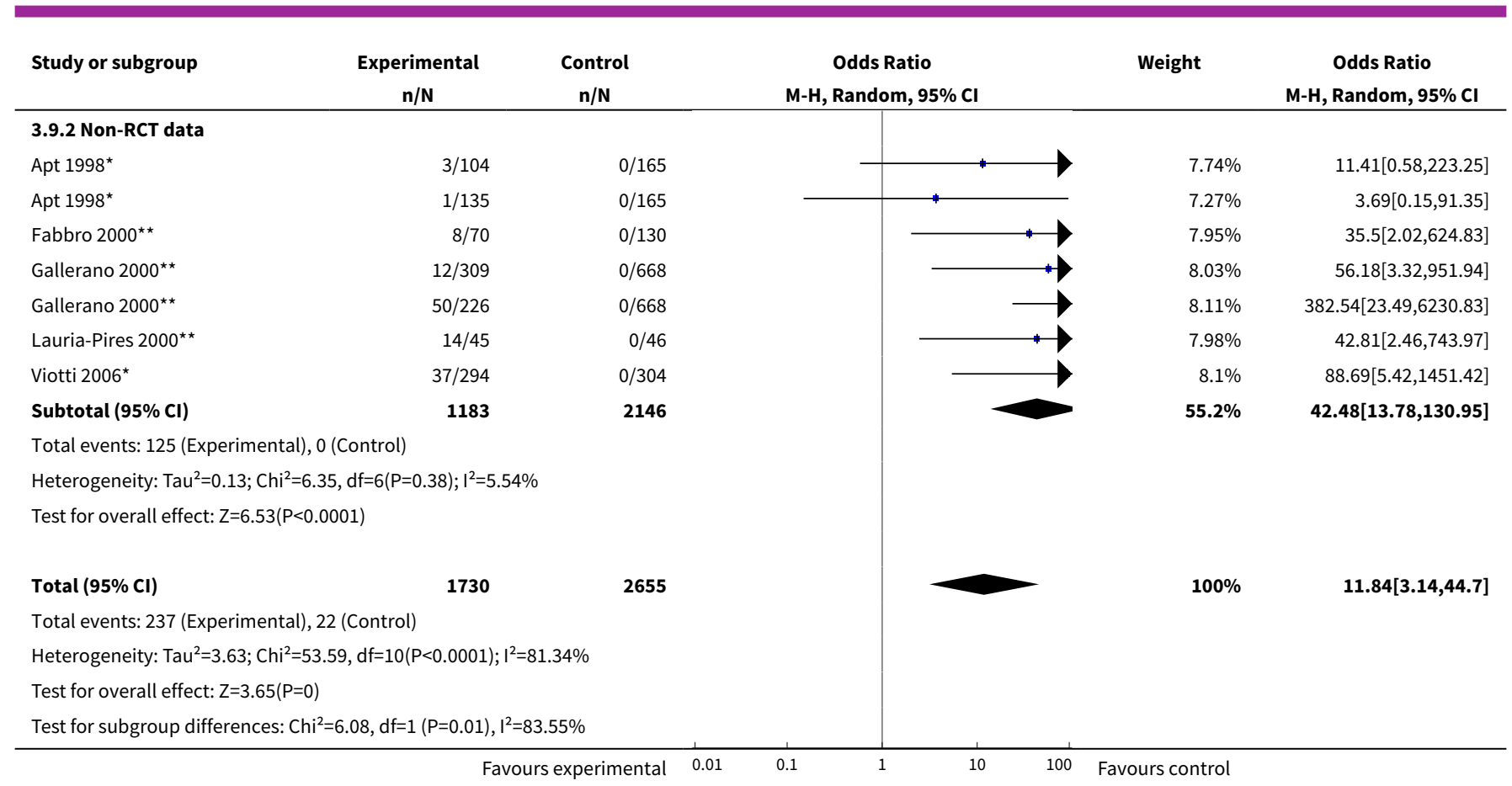

\section{APPENDICES}

\section{Appendix 1. Search strategies 2010}

\section{CENTRAL}

\#1 MeSH descriptor Chagas Disease explode all trees

\#2 chaga*

\#3 MeSH descriptor Trypanosoma cruzi, this term only

\#4 cruzi

\#5 trypanosomiasis

\#6 (\#1 OR \#2 OR \#3 OR \#4 OR \#5)

\#7 MeSH descriptor Trypanocidal Agents explode all trees

\#8 trypanocid*

\#9 MeSH descriptor Nitrofurans explode all trees

\#10 MeSH descriptor Allopurinol, this term only

\#11 MeSH descriptor Itraconazole, this term only

\#12 nifurtimox

\#13 allopurinol

\#14 Zyloprim

\#15 Zyloric

\#16 benznidazol ${ }^{\star}$

\#17 itraconazol*

\#18 Sporanox

\#19 antitrypanosom*

\#20 anti-trypanosom*

\#21 nitrofuran*

\#22 Macrobid

\#23 Macrodantin

\#24 bzd

\#25 MeSH descriptor Amiodarone, this term only

\#26 MeSH descriptor Amitriptyline, this term only

\#27 MeSH descriptor Pravastatin, this term only

\#28 MeSH descriptor Alendronate, this term only 
\#29 amitriptilin* \#30 amitriptylin* \#31 Triptafen \#32 Elavil \#33 pravastatin* \#34 Pravachol \#35 Lipostat \#36 alendronat* \#37 alendronic \#38 Fosamax \#39 amiodaron* \#40 Cordarone \#41 (\#7 OR \#8 OR \#9 OR \#10 OR \#11 OR \#12 OR \#13 OR \#14 OR \#15 OR \#16 OR \#17 OR \#18 OR \#19 OR \#20 OR \#21 OR \#22 OR \#23 OR \#24 OR \#25 OR \#26 OR \#27 OR \#28 OR \#29 OR \#30 OR \#31 OR \#32 OR \#33 OR \#34 OR \#35 OR \#36 OR \#37 OR \#38 OR \#39 OR \#40) \#42 (\#6 AND \#41)

\section{MEDLINE}

1. exp Chagas Disease/

2. Trypanosomiasis/

3. chaga\$.tw.

4. trypanosomiasis.tw.

5. Trypanosoma cruzi/

6. cruzi\$.tw.

7. or/1-6

8. exp Trypanocidal Agents/

9. trypanocid\$.tw.

10. exp Nitrofurans/

11. Allopurinol/

12. Itraconazole/

13. nifurtimox.tw.

14. allopurinol.tw.

15. Zyloprim.tw.

16. Zyloric.tw.

17. benznidazol\$.tw.

18. itraconazol\$.tw.

19. Sporanox.tw.

20. antitrypanosom\$.tw.

21. anti-trypanosom $\$ . t w$.

22. nitrofuran\$.tw.

23. Macrobid.tw.

24. Macrodantin.tw.

25. bzd.tw.

26. Amiodarone/

27. Amitriptyline/

28. Pravastatin/

29. Alendronate/

30. amitriptilin\$.tw.

31. amitriptylin\$.tw.

32. Triptafen.tw.

33. Elavil.tw.

34. pravastatin\$.tw.

35. Pravachol.tw.

36. Lipostat.tw.

37. alendronat\$.tw.

38. alendronic.tw.

39. Fosamax.tw.

40. amiodaron\$.tw.

41. Cordarone.tw.

42. Pacerone.tw.

43. or/8-42

44. 7 and 43 
45. exp animals/ not humans.sh.

46. 44 not 45

47. (199911\$ or $199912 \$$ or $20 \$) . e d$.

48.46 and 47

\section{EMBASE}

1. Chagas disease/

2. trypanosomiasis/

3. chaga\$.tw.

4. trypanosomiasis.tw.

5. trypanosoma cruzi/

6. cruzi\$.tw.

7. or/1-6

8. exp antitrypanosomal agent/

9. trypanocid\$.tw.

10. exp nitrofuran derivative/

11. allopurinol/

12. nifurtimox/

13. benznidazole/

14. itraconazole/

15. nifurtimox.tw.

16. allopurinol.tw.

17. Zyloprim.tw.

18. Zyloric.tw.

19. benznidazol\$.tw.

20. itraconazol\$.tw.

21. Sporanox.tw.

22. antitrypanosom\$.tw.

23. anti-trypanosom $\$$.tw.

24. nitrofuran\$.tw.

25. Macrobid.tw.

26. Macrodantin.tw.

27. bzd.tw.

28. amiodarone/

29. amitriptyline/

30. pravastatin/

31. alendronic acid/

32. amitriptilin\$.tw.

33. amitriptylin\$.tw.

34. Triptafen.tw.

35. Elavil.tw.

36. pravastatin\$.tw.

37. Pravachol.tw.

38. Lipostat.tw.

39. alendronat\$.tw.

40. alendronic.tw.

41. Fosamax.tw.

42. amiodaron\$.tw.

43. Cordarone.tw.

44. Pacerone.tw.

45. or/8-44

46. 7 and 45

47. (animal/ or nonhuman/) not human/

48. 46 not 47

49. (20\$ not "200001").em.

50.48 and 49

\section{LILACS}

(chaga or trypanosom\$ or cruzi) [Words] and (antitrypanocidal\$ or anti-trypanocidal\$ or trypanocid\$ or nitrofuran\$ or Macrobid or Macrodantin or bzd or nifurtimox or allopurinol or Zyloprim or Zyloric or benznidazol\$ or itraconazol\$ or Sporanox or antitrypanosom 
\$ or anti-trypanosom\$ or amiodaron\$ or Cordarone or Pacerone or amitriptilin\$ or amitriptylin\$ or Triptafen or Elavil or pravastatin\$ or Pravachol or Lipostat or alendronat\$ or alendronic or Fosamax) [Words] and 20\$ [Country, year publication]

\section{Appendix 2. Search strategies 2014}

\section{CENTRAL}

\#1 MeSH descriptor Chagas Disease explode all trees

\#2 chaga*

\#3 MeSH descriptor Trypanosoma cruzi, this term only

\#4 cruzi

\#5 trypanosomiasis

\#6 (\#1 OR \#2 OR \#3 OR \#4 OR \#5)

\#7 MeSH descriptor Trypanocidal Agents explode all trees

\#8 trypanocid ${ }^{\star}$

\#9 MeSH descriptor Nitrofurans explode all trees

\#10 MeSH descriptor Allopurinol, this term only

\#11 MeSH descriptor Itraconazole, this term only

\#12 nifurtimox

\#13 allopurinol

\#14 Zyloprim

\#15 Zyloric

\#16 benznidazol ${ }^{*}$

\#17 itraconazol $^{*}$

\#18 Sporanox

\#19 antitrypanosom*

\#20 anti-trypanosom ${ }^{\star}$

\#21 nitrofuran ${ }^{\star}$

\#22 Macrobid

\#23 Macrodantin

\#24 bzd

\#25 MeSH descriptor Amiodarone, this term only \#26 MeSH descriptor Amitriptyline, this term only

\#27 MeSH descriptor Pravastatin, this term only

\#28 MeSH descriptor Alendronate, this term only

\#29 amitriptilin*

\#30 amitriptylin ${ }^{\star}$

\#31 Triptafen

\#32 Elavil

\#33 pravastatin*

\#34 Pravachol

\#35 Lipostat

\#36 alendronat*

\#37 alendronic

\#38 Fosamax

\#39 amiodaron*

\#40 Cordarone

\#41 (\#7 OR \#8 OR \#9 OR \#10 OR \#11 OR \#12 OR \#13 OR \#14 OR \#15 OR \#16 OR \#17 OR \#18 OR \#19 OR \#20 OR \#21 OR \#22 OR \#23 OR \#24 OR \#25 OR \#26 OR \#27 OR \#28 OR \#29 OR \#30 OR \#31 OR \#32 OR \#33 OR \#34 OR \#35 OR \#36 OR \#37 OR \#38 OR \#39 OR \#40)

\#42 (\#6 AND \#41)

\section{MEDLINE}

1. exp Chagas Disease/

2. Trypanosomiasis/

3. chagas.tw.

4. trypanosomiasis.tw.

5. Trypanosoma cruzi/

6. cruzi\$.tw.

7. or/1-6

8. exp Trypanocidal Agents/

9. trypanocid\$.tw.

10. exp Nitrofurans/ 
11. Allopurinol/

12. Itraconazole/

13. nifurtimox.tw.

14. allopurinol.tw.

15. Zyloprim.tw.

16. Zyloric.tw.

17. benznidazol\$.tw.

18. itraconazol\$.tw.

19. Sporanox.tw.

20. antitrypanosom\$.tw.

21. anti-trypanosom\$.tw.

22. nitrofuran\$.tw.

23. Macrobid.tw.

24. Macrodantin.tw.

25. bzd.tw.

26. Amiodarone/

27. Amitriptyline/

28. Pravastatin/

29. Alendronate/

30. amitriptilin\$.tw.

31. amitriptylin\$.tw.

32. Triptafen.tw.

33. Elavil.tw.

34. pravastatin\$.tw.

35. Pravachol.tw.

36. Lipostat.tw.

37. alendronat\$.tw.

38. alendronic.tw.

39. Fosamax.tw.

40. amiodaron\$.tw.

41. Cordarone.tw.

42. Pacerone.tw.

43. or/8-42

44.7 and 43

45. exp animals/ not humans.sh.

46. 44 not 45

47. randomized controlled trial.pt.

48. controlled clinical trial.pt.

49. randomized.ab.

50. placebo.ab.

51. drug therapy.fs.

52. randomly.ab.

53. trial.ab.

54. groups.ab.

55.47 or 48 or 49 or 50 or 51 or 52 or 53 or 54

56. exp animals/ not humans.sh.

57.55 not 56

58.46 and 57

59. $\left(201004^{\star}\right.$ or $201005^{\star}$ or $201006^{\star}$ or $201007^{\star}$ or $201008^{\star}$ or $201009^{\star}$ or $20101^{\star}$ or $2011^{\star}$ or $2012^{\star}$ or $2013^{\star}$ or $\left.2014^{\star}\right)$.ed.

60.58 and 59

\section{EMBASE}

1. Chagas disease/

2. trypanosomiasis/

3. chaga\$.tw.

4. trypanosomiasis.tw.

5. trypanosoma cruzi/

6. cruzi\$.tw.

7. or/1-6

8. exp antitrypanosomal agent/

9. trypanocid\$.tw. 
10. exp nitrofuran derivative/

11. allopurinol/

12. nifurtimox/

13. benznidazole/

14. itraconazole/

15. nifurtimox.tw.

16. allopurinol.tw.

17. Zyloprim.tw.

18. Zyloric.tw.

19. benznidazol\$.tw.

20. itraconazol\$.tw.

21. Sporanox.tw.

22. antitrypanosom $\$ . t w$.

23. anti-trypanosom $\$$.tw.

24. nitrofuran\$.tw.

25. Macrobid.tw.

26. Macrodantin.tw.

27. bzd.tw.

28. amiodarone/

29. amitriptyline/

30. pravastatin/

31. alendronic acid/

32. amitriptilin\$.tw.

33. amitriptylin\$.tw.

34. Triptafen.tw.

35. Elavil.tw.

36. pravastatin\$.tw.

37. Pravachol.tw.

38. Lipostat.tw.

39. alendronat\$.tw.

40. alendronic.tw.

41. Fosamax.tw.

42. amiodaron\$.tw.

43. Cordarone.tw.

44. Pacerone.tw.

45. or/8-44

46.7 and 45

47. (animal/ or nonhuman/) not human/

48. 46 not 47

49. random\$.tw.

50. factorial\$.tw.

51. crossover\$.tw.

52. cross over\$.tw.

53. cross-over\$.tw.

54. placebo\$.tw.

55. (doubl\$ adj blind\$).tw.

56. (singl\$ adj blind\$).tw.

57. assign\$.tw.

58. allocat\$.tw.

59. volunteer\$.tw.

60. crossover procedure/

61 . double blind procedure/

62. randomized controlled trial/

63. single blind procedure/

64.49 or 50 or 51 or 52 or 53 or 54 or 55 or 56 or 57 or 58 or 59 or 60 or 61 or 62 or 63

65. (animal/ or nonhuman/) not human/

66.64 not 65

67.48 and 66

68. $\left(2010^{\star}\right.$ or $2011^{\star}$ or $2012^{\star}$ or $2013^{\star}$ or $\left.2014^{\star}\right)$.em.

69. $\left(2010^{\star}\right.$ or $2011^{\star}$ or $2012^{\star}$ or $2013^{\star}$ or $\left.2014^{\star}\right)$.dd.

70.68 or 69

71.67 and 70 
WHAT'S NEW

\begin{tabular}{lll}
\hline Date & Event & Description \\
\hline 16 May 2014 & $\begin{array}{l}\text { New citation required but conclusions } \\
\text { have not changed }\end{array}$ & $\begin{array}{l}\text { Searches re-run eight new studies included with conclusions not } \\
\text { changed }\end{array}$ \\
\hline 17 March 2014 & New search has been performed & Searches were re-run in February 2014. \\
\hline
\end{tabular}

\section{CONTRIBUTIONS OF AUTHORS}

JC Villar designed the protocol, reviewed the data extracted and drafted this review.

OL Cortés, JG Pérez and MR Pepper classified the references, assessed studies for inclusion and extracted data.

All other authors had access to the data recorded and critically reviewed the protocol and manuscript.

\section{DECLARATIONS OF INTEREST}

Dr. Riarte is the principal investigator of TRAENA, one of the studies included in this review. Dr. Marin-Neto is one of the co-principal investigators of the BENEFIT trial. All other authors declare having no conflict of interest.

\section{IN DEX TERMS}

\section{Medical Subject Headings (MeSH)}

Chagas Cardiomyopathy [prevention \& control]; Chagas Disease [*drug therapy]; Chronic Disease; Observational Studies as Topic; Randomized Controlled Trials as Topic; Trypanocidal Agents [ ${ }^{\star}$ therapeutic use]; Trypanosoma cruzi

\section{MeSH check words}

Animals; Humans 